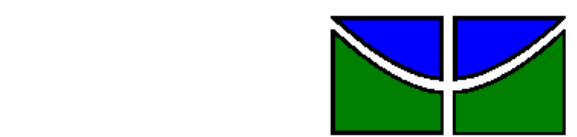

Universidade de Brasília

Faculdade de Economia, Administração e Contabilidade

Departamento de Administração

SÍLVIA SABÓIA GUALBERTO

\title{
MODELOS DE GESTÃO DA INOVAÇÃO ADOTADOS POR EMPRESAS DE SERVIÇOS DE SOFTWARE ATUANTES NO DISTRITO FEDERAL
}

Brasília - DF

2010 


\section{SÍLVIA SABÓIA GUALBERTO}

\section{MODELOS DE GESTÃO DA INOVAÇÃO ADOTADOS POR EMPRESAS DE SERVIÇOS DE SOFTWARE ATUANTES NO DISTRITO FEDERAL}

Monografia apresentada ao

Departamento de Administração como requisito parcial à obtenção do título de Bacharel em Administração.

Professora Orientadora: Mestre, Marina

Figueiredo Moreira

Brasília - DF 
Gualberto, Sílvia Sabóia.

Modelos de Gestão da Inovação Adotados por Empresas de Serviços de Software Atuantes no Distrito Federal / Sílvia Sabóia Gualberto. - Brasília, 2010. $113 \mathrm{f}$. : il.

Monografia (bacharelado) - Universidade de Brasília, Departamento de Administração, 2010.

Orientadora: Prof. Msc. Marina Figueiredo Moreira, Departamento de Administração.

1. Modelos de Gestão da Inovação. 2. Serviços de Software. 3. Inovação em Serviços I. Título. 


\title{
MODELOS DE GESTÃO DA INOVAÇÃO ADOTADOS POR EMPRESAS DE SERVIÇOS DE SOFTWARE ATUANTES NO DISTRITO FEDERAL
}

\begin{abstract}
A Comissão Examinadora, abaixo identificada, aprova o Trabalho de Conclusão do Curso de Administração da Universidade de Brasília da aluna
\end{abstract}

\section{Sílvia Sabóia Gualberto}

Mestre, Marina Figueiredo Moreira

Professora-Orientadora

Doutora, Doriana Daroit

Professor-Examinador
Mestre, Luciene Braz Ferreira

Professor-Examinador

Brasília, 27 de agosto de 2010. 


\section{AGRADECIMENTOS}

À professora Marina Figueiredo Moreira, minha orientadora, pelo incentivo e pelas constantes trocas de conhecimento.

Aos entrevistados, que tanto contribuíram para este estudo: Luiz Garcia, Felipe Rodrigues, Luciano Silva, Hermanno Ribeiro, Leonardo Soares e Hiraclis Junior.

A meus pais, Aluísio e Virgínia, que acreditaram em meu potencial. 
"Nenhum incentivo é tão eficaz quanto a perspectiva de viver com o resultado do nosso trabalho". 


\section{RESUMO}

Este estudo descreve como ocorre o processo de gestão da inovação em empresas de serviços de software do Distrito Federal, buscando identificar casos típicos que podem ser considerados a melhor expressão deste processo no ramo de serviços escolhido. Procura, também, caracterizar cada inovação citada em modelos ou tipos de inovação empíricos. Trata-se de um estudo de casos múltiplos com a análise de seis casos de empresas, por meio de entrevistas semi-estruturadas realizadas com especialistas, sendo eles profissionais de nível gerencial das organizações. Utilizase a codificação temática para fazer a descrição e análise de cada caso. Nas análises, na etapa de caracterização das inovações, são relatadas melhorias em sistemas existentes, criação de ferramentas tecnológicas totalmente novas, novos segmentos-alvo de atuação, melhorias nos processos, melhorias na forma de atendimento ao cliente e aquisição de certificações. Todos os casos de inovação citados puderam ser analisados à luz de tipos de inovação teóricos. A análise dos tipos de inovação mostrou que as inovações mais recorrentes são inovações radicais. Menos comuns são as inovações pela recombinação e ad hoc. Foi possível observar uma inovação que se caracteriza tanto como inovação radical quanto como inovação ad hoc. Foram observados três casos de inovações pela formalização. Os resultados apontam que as fases de procura e seleção de inovações não costumam ter momentos específicos de ocorrência e geralmente estão atreladas às atividades da cúpula da empresa. $\mathrm{Na}$ análise das fases de execução e lançamento da inovação, a principal barreira à inovação é a resistência a mudanças. Constatou-se, ainda, que não são consideradas acessíveis as formas de financiamento propostas por órgãos fomentadores de inovações. Conclui-se que o setor de serviços de software está sofrendo um processo de mudança em seu modelo de negócio, visto que não é sustentável oferecer apenas soluções tecnológicas sem uma análise do contexto geral em que se insere o cliente. As empresas de serviços de software precisam compreender a importância desta nova forma de ação voltada à solução de problemas e disseminar esta visão de negócio a todos os seus níveis hierárquicos.

Palavras-chave: Modelos de Gestão da Inovação. Inovação em Serviços. Serviços de Software. 


\section{LISTA DE FIGURAS}

Figura 1 - O framework da inovação.............................................................. 21

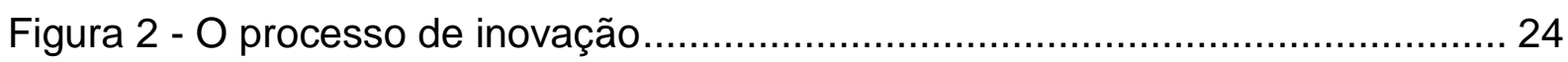

Figura 3 - Representação do processo de inovação ................................................. 25

Figura 4 - Technology Push (First Generation).................................................. 26

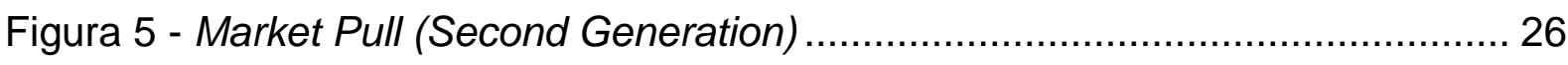

Figura 6 - The "Coupling" Model of Innovation (Third Generation) .......................... 27

Figura 7 - Example of the Integrated Innovation Process (Fourth Generation)......... 28

Figura 8 - Elementos essenciais do processo de inovação ……………………..... 29

Figura 9 - O produto como vetores de características e de competências colocados

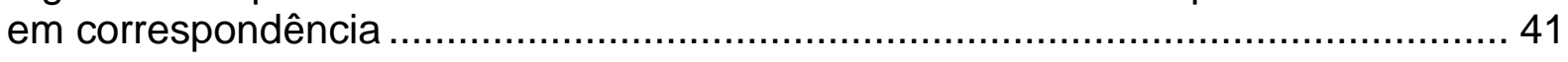

Figura 10 - O caso de um serviço puro, intangível ............................................... 42 


\section{LISTA DE QUADROS}

Quadro 1 - Blocos temáticos baseados no roteiro para descrição dos casos

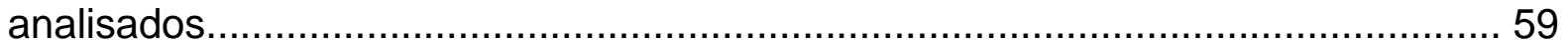

Quadro 2 - Identificação dos casos de inovação................................................... 98 


\section{LISTA DE TABELAS}

Tabela 1 - Balança Comercial Brasileira de Software (US\$ milhões) ..................... 46

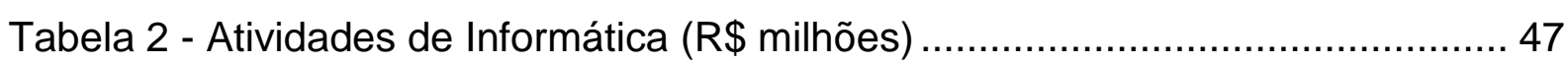

Tabela 3 - Comparativo de Tributação de Software -2002 .................................. 49 


\section{LISTA DE GRÁFICOS}

Gráfico 1 - Participação de cada um dos três setores no emprego total no Brasil (1950-1996): Agricultura, extração e pesca; Indústria e construção; e Serviços36

Gráfico 2 - PIB do Brasil por grandes setores - em preços de 1975 (milhões de cruzeiros).... 37

Gráfico 3 - Início das Atividades das Empresas de TI 48

Gráfico 4 - Porte das Empresas, segundo a força de trabalho (adaptado pela autora) 48

Gráfico 5 - Principais tipos de aplicação desenvolvidos 49

Gráfico 6 - Participação das atividades no segmento de serviços de informação

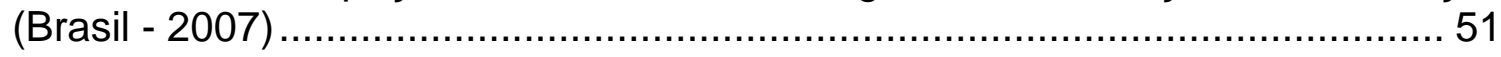

Gráfico 7 - Indicadores de Mercado e Evolução (US\$ Bilhões).......................... 52 


\section{LISTA DE ABREVIATURAS E SIGLAS}

ABES - Associação Brasileira das Empresas de Software

Assespro - Associação Brasileira das Empresas de Tecnologia da Informação

BPO - Business Process Outsourcing

CMMI - Capability Maturity Model Integration

ERP - Enterprise Resource Planning

FINEP - Financiadora de Estudos e Projetos

GED - Gerenciamento Eletrônico de Documentos

GVE - Gestão de Vetores Epidemiológicos

IBGE - Instituto Brasileiro de Geografia e Estatística

ISO - International Organization for Standardization

ITIL - Information Technology Infrastructure Library

NPS - Net Promoter Score

OMC - Organização Mundial do Comércio

PAS - Pesquisa Anual de Serviços

PIB - Produto Interno Bruto

P\&D - Pesquisa e Desenvolvimento

PMBOK - Project Management Body of Knowledge

PMO - Project Management Office

PMO - Project Management Officer

Sepin - Secretaria de Política de Informática do Ministério da Ciência e Tecnologia

SBQS - Sociedade Brasileira de Qualidade de Software

Temaguide - Guide to Technology Management and Innovation for Companies

TI - Tecnologia da Informação 


\section{SUMÁRIO}

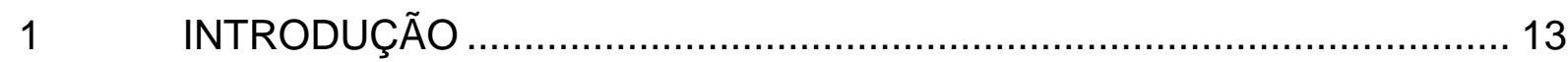

$1.1 \quad$ Formulação do problema …………………..................................... 14

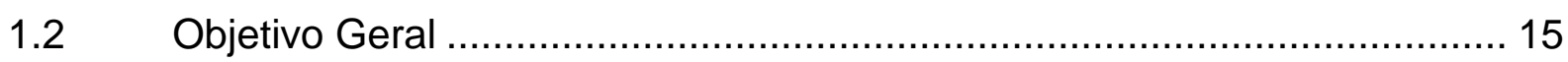

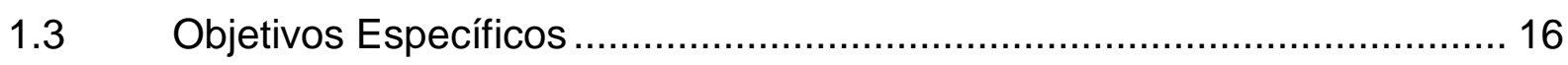

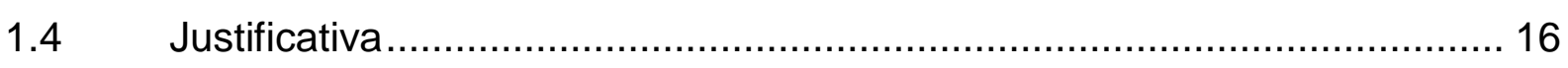

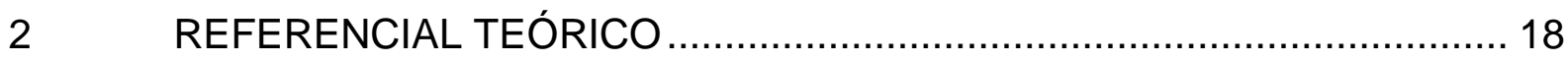

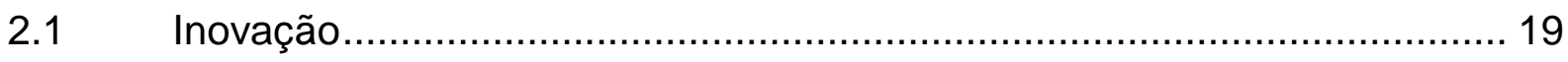

2.1.1 Inovação - Definições, Tipos e Dimensões …………………………..... 19

2.1.2 Modelos de Gestão da Inovação ........................................................ 22

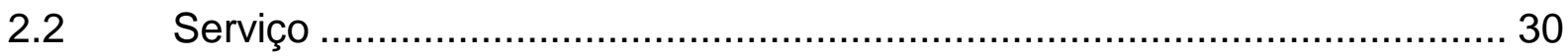

2.2.1 O Setor de Serviços - Definições e Características ................................... 30

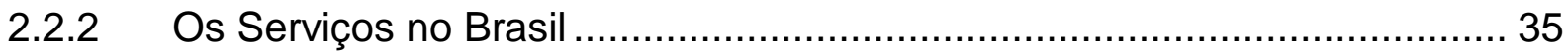

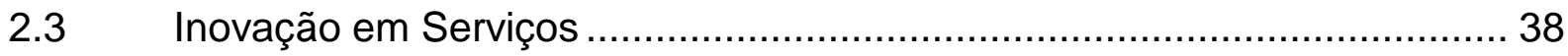

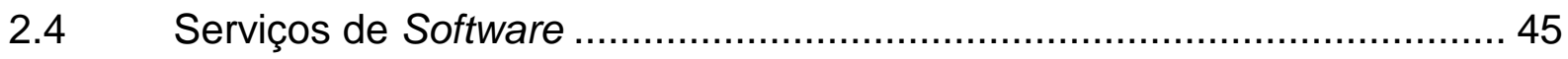

2.4.1 O Setor de Softwares no Brasil ............................................................ 45

2.4.2 Subsídios à Inovação em Serviços de Software ....................................... 52

3 MÉTODOS E TÉCNICAS DE PESQUISA............................................5 54

3.1 Tipo e descrição geral da pesquisa ......................................................... 54

3.2 Caracterização do setor e das organizações estudadas............................ 56

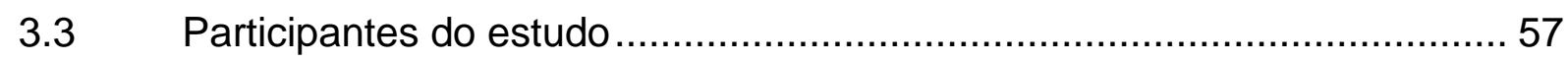

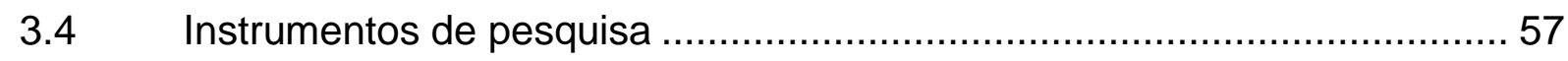

3.5 Procedimentos de coleta e de análise de dados ..................................... 59

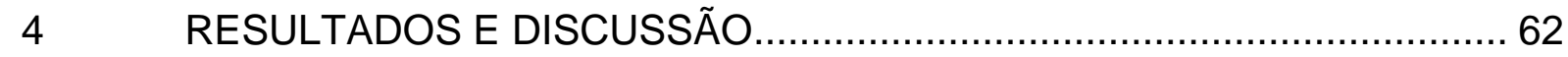

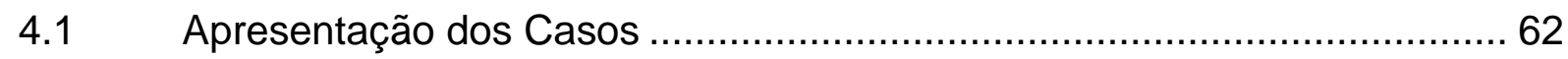

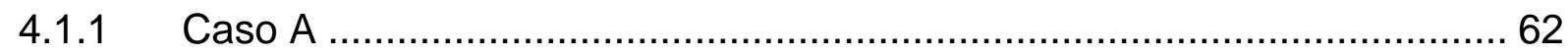




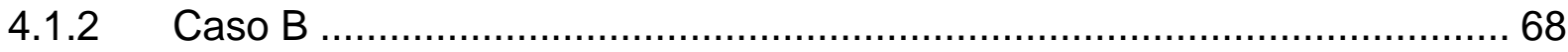

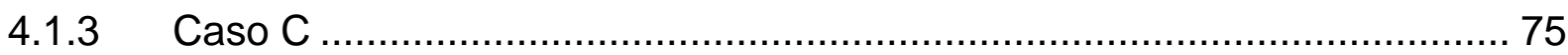

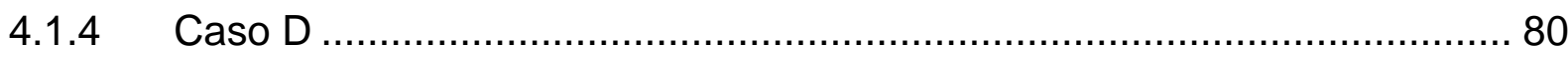

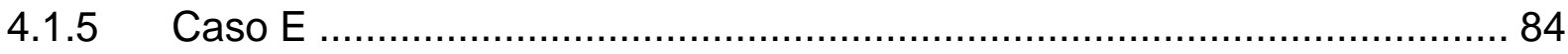

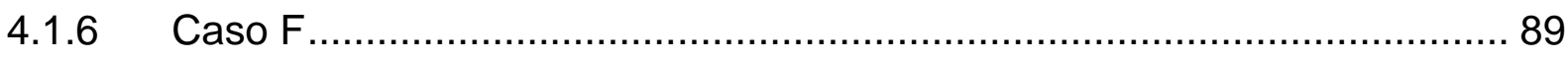

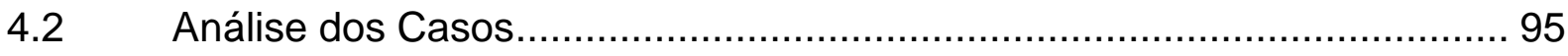

4.2.1 Confrontação das inovações relatadas em cada caso com os tipos de

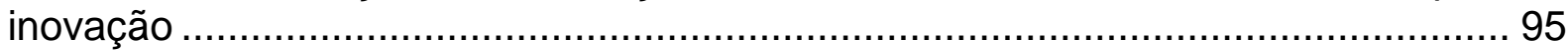

4.2.2 Análise das fases de Procura e Seleção de ideias..................................... 99

4.2.3 Análise da fase de Aquisição de conhecimentos ................................... 100

4.2.4 Análise das fases de Execução e Lançamento da inovação.................... 100

4.2.5 Análise das fases de Sustentabilidade e Aprendizado adquirido com a

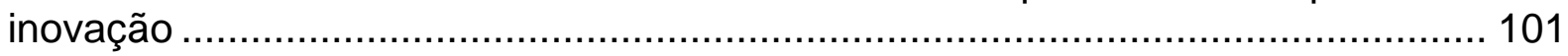

$5 \quad$ CONCLUSÕES E RECOMENDAÇÕES …….................................... 103

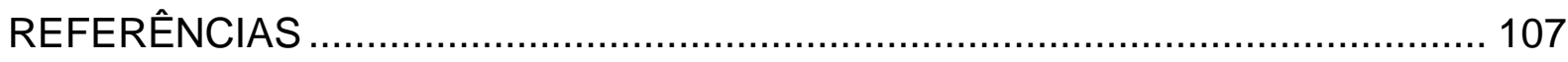

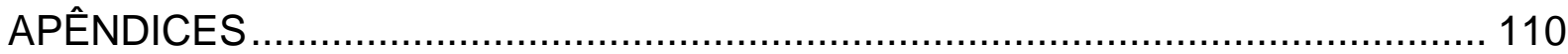

Apêndice A - Roteiro de Entrevista ................................................................. 110

Apêndice B - Organograma do Caso A........................................................ 112

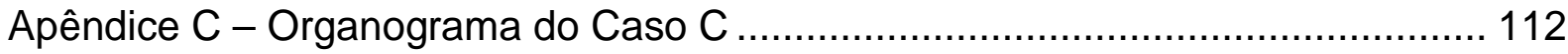

Apêndice D - Organograma do Caso D ........................................................ 113 


\section{INTRODUÇÃO}

O setor de serviços vem se tornando mais representativo e importante na economia dos países com o decorrer dos anos. No caso do Brasil, a participação dos serviços nos níveis de emprego e de salários pagos é mais significativa a cada dia, de acordo com dados da Pesquisa Anual de Serviços de 2007.

Segundo Tidd, Bessant e Pavitt (2008), a capacidade de prestar melhores serviços - mais rápidos, mais baratos, de melhor qualidade - já é há muito considerada fonte de vantagem competitiva.

Dada a importância da vantagem competitiva para os serviços, uma constatação relevante é que existe forte correlação entre o desempenho mercadológico e a capacidade de uma empresa de inovar. Porém, as inovações perdem seu poder competitivo à medida que outros as imitam.

A menos que a organização seja capaz de progredir para uma inovação
ainda maior, arrisca-se a ficar para trás, já que os demais tomam a
liderança ao mudarem suas ofertas, processos operacionais ou modelos
que orientam seus negócios. (TIDD; BESSANT; PAVITT, 2008, p. 26).

Sendo assim, as empresas precisam conhecer e estruturar um processo de gestão da inovação adequado ao seu negócio, de forma que se antecipem frente às oportunidades e ameaças do mercado e que consigam efetivamente transformar invenções em instrumentos de geração de valor para si e para os consumidores. Nos serviços, visto sua característica principal de intangibilidade, este processo de gestão da inovação mostra-se ainda mais necessário.

A inovação é um processo, não um evento isolado, e precisa ser gerenciada
como tal. [E] as influências sobre esse processo podem ser manipuladas
para afetar o resultado - ou seja, a inovação pode ser gerenciada. (TIDD;
BESSANT; PAVITT, 2008, p. 107).

Sabendo que a inovação pode ser gerenciada, mostra-se conveniente fornecer às empresas a possibilidade de conhecer as melhores práticas existentes de execução desta gestão, buscando pontos comuns a serem compartilhados. 


\subsection{Formulação do problema}

Os serviços possuem características bastante específicas que por muitos anos foram pouco exploradas por estudiosos, já que eram vistos como atividades de nível inferior e que não agregavam riqueza para a economia. Nas atividades de serviços, as inovações geralmente ocorrem de forma não linear e são impactadas pelo fator humano muito mais do que pela tecnologia - já que habilidades como conhecimento organizacional, experiência dos funcionários e relacionamento com clientes são fundamentais.

Porém, a crescente importância das atividades de serviços nas principais economias está despertando grande interesse no sentido de se compreender a dinâmica dessas atividades, suas implicações e relações com os demais setores.

Além disso, nos dias atuais, a intensificação das mudanças no ambiente empresarial faz com que as organizações precisem estar a cada momento desenvolvendo novos métodos de apresentação de seus produtos, processos e até mesmo de seus modelos de negócios, a fim de alcançarem vantagem competitiva frente aos concorrentes. Neste cenário, a inovação apresenta-se como uma peça fundamental.

Mesmo com a constatação de que são poucas as empresas de serviços que possuem um departamento de Pesquisa e Desenvolvimento (P\&D), há um esforço crescente dessas empresas para sistematizar e gerir a inovação (SUNDBO, 1997). A inovação é mais do que conceber uma nova ideia; é o processo de desenvolver seu uso prático. Neste sentido, a contribuição deste estudo se dá por meio da análise de modelos de gestão de inovação apresentados por empresas prestadoras de serviços e da análise dos tipos de inovação existentes nesse processo.

A dificuldade deste debate reside, por um lado, na complexidade da definição dos serviços, principalmente no que diz respeito à definição do produto do serviço, e, por outro, no fato de que a teoria da inovação, por várias décadas mais dedicada à análise da evolução das atividades produtivas, ainda não contempla as atividades de serviços de maneira totalmente satisfatória. 
Visto que a inovação pressupõe incerteza, uma vez que os resultados do esforço inovador dificilmente podem ser conhecidos de antemão, fica clara a importância de se entender a inovação enquanto processo, pois é esse conhecimento que molda a forma como a experimentamos e gerenciamos.

Em adição à contribuição para as pesquisas, este estudo enfoca o setor de softwares, setor este que vem se colocando como um instrumento de ligação entre as várias cadeias produtivas das empresas, sendo crescentemente utilizado em todos os aspectos de negócio. Empresas estão realizando grandes investimentos em software, em aplicações que vão desde a comercialização de seus produtos ao controle interno das cadeias de valores.

As empresas prestadoras de serviços - focalizando neste estudo as empresas de serviços de software - possuem dificuldades de trabalhar de forma efetiva sua gestão, apesar de possuírem competências técnicas especializadas bem desenvolvidas. A inovação em serviços em geral ainda é pouco explorada, e, tendo as empresas de serviços de softwares necessidades de aprimoramentos constantes em suas soluções, são inegáveis as vantagens de se trabalhar a gestão da inovação nesta categoria de serviços. Além disso, a gestão da inovação no setor de softwares pode auxiliar na busca de destaque desse setor perante as empresas multinacionais estrangeiras.

Diante do exposto, e visto a importância de se desenvolver cada vez mais o setor de softwares no país, espera-se com este trabalho responder à seguinte questão: Como são os modelos de gestão da inovação adotados por empresas de serviços de software atuantes no Distrito Federal?

\subsection{Objetivo Geral}

Analisar os modelos de gestão da inovação adotados por empresas de serviços de software atuantes no Distrito Federal. 


\subsection{Objetivos Específicos}

a) Investigar teoricamente os modelos existentes relacionados ao processo de gestão da inovação, buscando um modelo que represente de forma apropriada a dinâmica do setor de serviços;

b) Verificar, de acordo com os modelos de gestão da inovação, como está estruturado o processo de gestão da inovação nas empresas de serviços de software.

c) Identificar, nos casos selecionados, as inovações surgidas na prestação de serviços de software;

d) Caracterizar os tipos de inovação observados, de acordo com a abordagem prevista na teoria de inovação em serviços.

\subsection{Justificativa}

O tema proposto neste estudo é o de descrever e analisar como ocorrem os processos de gestão da inovação em empresas prestadoras de serviços de software.

A razão da escolha do tema se dá, inicialmente, pelo fato de o setor de serviços ter sido, até então, pouco explorado no âmbito da inovação e da gestão da inovação. A segunda razão, não menos importante, é a existência de intensas e contínuas melhorias observadas nas empresas prestadoras de serviços de software nos dias atuais. A competitividade do setor de Tecnologia da Informação ( $\mathrm{TI}$ ) vem se mostrando cada vez mais intensa, o que exige que as empresas nele atuantes desenvolvam constantemente projetos e processos inovadores.

A importância deste estudo se dá, então, pela oportunidade de trazer à tona a realidade de um setor extremamente focado em inovação, divulgando a forma como as empresas nele inseridas se utilizam da inovação em seu dia-a-dia e como realizam a gestão da inovação, visando o desenvolvimento de melhores serviços, processos e tecnologias. 
Visto o pouco foco dado até então para estudos sobre inovação em serviços, este trabalho se propõe a contribuir e complementar as pesquisas já realizadas neste tema. O estudo será útil, ainda, para estimular a realização de novas pesquisas no campo de gestão da inovação nos mais diferentes setores de serviços.

Esta pesquisa mostra também sua contribuição a partir da análise, em casos práticos, das teorias de gestão da inovação propostas empiricamente.

Portanto, o presente estudo se insere no esforço de colaborar para o avanço das pesquisas sobre modelos de gestão da inovação, em uma perspectiva que contribua para a melhor definição da dinâmica da inovação em serviços. 


\section{REFERENCIAL TEÓRICO}

Esta seção subdivide-se em quatro grandes partes. Inicialmente a atenção se volta para o fenômeno da inovação, onde são explicitadas definições, tipos de inovação - as diversas formas como as inovações podem se apresentar - e as diferentes dimensões em que uma inovação pode ocorrer. Esta primeira etapa da exposição é extremamente importante para que se compreenda o que vem a seguir, que abrange o gerenciamento do processo de inovação, ou os modelos de gestão da inovação propostos com base em pesquisas empíricas realizadas.

Em sequência, a segunda parte explicita o campo de pesquisa deste estudo. Aqui se procura percorrer os conceitos e caracterizações adotados pelo setor de serviços durante diversos momentos históricos. As diferentes interpretações dos serviços são mostradas de forma cronológica, de maneira a facilitar o entendimento da importância adquirida por tal setor na atualidade. Logo após é feita uma explanação sobre o setor de serviços no Brasil, concluindo a segunda parte.

A partir daí, na terceira parte do estudo, tendo-se compreendido de forma ampla a inovação e as particularidades do setor de serviços, é feita uma investigação sobre a inovação em serviços, tema ainda pouco compreendido na atual economia.

Por fim, a quarta parte busca situar o leitor no ramo específico de serviços que será analisado neste estudo, que é o ramo de empresas prestadoras de serviços de software. É desenvolvida uma explicação sobre o conceito de software e de serviços de software, e há ênfase na descrição da atuação desses serviços no Brasil, bem como nos mecanismos de subsídio à inovação aplicáveis aos serviços de software. 


\subsection{Inovação}

\subsubsection{Inovação - Definições, Tipos e Dimensões}

Pode-se definir um negócio inovador como "aquele que vive e respira fora dos padrões. Não se trata apenas de boas ideias, mas de uma combinação das mesmas com uma equipe motivada e uma compreensão instintiva sobre o que seu cliente necessita”. (BRANSON, 1998 apud TIDD; BESSANT; PAVITT, 2008, p. 86)

Na visão de Davila, Epstein e Shelton (2007), a inovação pode ocorrer no modelo de negócio de uma empresa ou por meio de uma tecnologia empregada. $O$ modelo de negócio de uma empresa define a maneira pela qual ela cria, vende e proporciona valor aos seus clientes. Os elementos que garantem a ocorrência de inovações no modelo de negócios são:

a) Proposição de valor da empresa: compreende o que se vende e o que se lança no mercado. A mudança pode surgir em um produto ou serviço inteiramente novo ou em uma melhoria de algo que já existe.

b) Cadeia de suprimentos: estas mudanças são aquelas que normalmente os clientes não veem. É uma mudança que afeta a maneira pela qual a empresa se organiza a fim de produzir e entregar seus produtos e serviços.

c) Clientes-alvo: são mudanças que ocorrem quando a organização identifica um segmento de clientes e decide atuar nele.

Há ocasiões em que novas tecnologias representam a parte mais importante de uma inovação. Os elementos essenciais para a inovação tecnológica são:

a) Lançamento de produtos e serviços: em um mercado em permanente mutação, os clientes se acostumaram a esperar por mudanças tecnológicas significativas e recorrentes em produtos. Exemplos de inovação tecnológica em produtos são novos itens lançados em celulares ou automóveis. 
b) Processos tecnológicos: são inovações normalmente invisíveis para os clientes, porém vitais para a posição competitiva de um produto. Exemplos de processos tecnológicos são as tecnologias de processamento de alimentos e de produção de automóveis. Os objetivos destas inovações costumam ser redução de custos e aumento da qualidade dos produtos e serviços.

c) Tecnologias capacitadoras: são também mudanças normalmente invisíveis para os clientes. Compreendem tecnologias que capacitam a empresa a executar sua estratégia com maior rapidez para obter vantagem competitiva, sem mudar a funcionalidade do produto ou processo. Um exemplo é a tecnologia da informação, que torna mais fácil o intercâmbio de informações entre as diversas áreas da empresa.

E a inovação, segundo Davila, Epstein e Shelton (2007), envolve mudanças em um ou mais desses seis elementos. A preocupação principal é que haja integração e alinhamento entre as inovações que ocorrem no modelo de negócio e nas tecnologias adotadas pelas empresas.

Os autores acima também comentam que nem todas as inovações são criadas da mesma forma. Logo, definem três tipos de inovação para caracterizá-las: inovação incremental, semi-radical e radical.

A inovação incremental é a forma predominante de inovação na maioria das empresas e leva a melhorias moderadas nos produtos e processos de negócios em vigor. É uma maneira de extrair o máximo valor dos bens e serviços existentes sem a necessidade de fazer mudanças significativas ou grandes investimentos.

A escassez de inovação incremental pode constituir enorme ameaça ao
sucesso de qualquer empresa, pois ela permite que os concorrentes
acabem tirando proveito das inovações passadas e atraindo clientes pelo
uso de tecnologias e modelos de negócios que são simplesmente cópias
daqueles anteriormente lançados pelas pioneiras. (DAVILA; EPSTEIN;
SHELTON, 2007, p. 63).

A inovação semi-radical envolve mudança substancial no modelo de negócios ou na tecnologia de uma organização, mas não em ambas. A título de exemplo, quando uma empresa emprega inovação semi-radical significativa em seu modelo de negócio, consequentemente aplicará uma mudança pequena em tecnologia, e viceversa. 
Já a inovação radical é aquela mudança significativa que afeta simultaneamente tanto o modelo de negócios quanto a tecnologia de uma empresa. Costuma estar relacionada a mudanças fundamentais no cenário competitivo de um setor. Quando uma empresa está em busca de investidores para inovações radicais, a dificuldade se encontra no fato de muitos serem avessos a aceitar os riscos envolvidos, já que os resultados futuros de uma inovação como essa são de difícil mensuração.

A Matriz da Inovação mostrada na Figura 1 apresenta de forma resumida quando se observam cada um dos tipos de inovação.

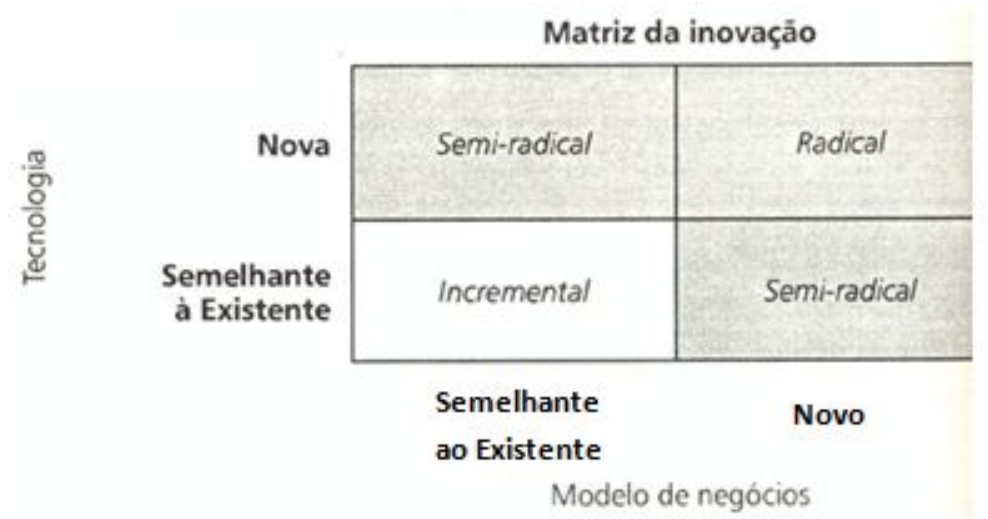

Figura 1 - O framework da inovação

Fonte: Davila, Epstein e Shelton (2007)

\begin{abstract}
Enquanto a vantagem competitiva pode advir de tamanho e patrimônio, entre outros fatores, o cenário está gradativamente mudando em favor daquelas organizações que conseguem mobilizar conhecimento e avanços tecnológicos e conceber a criação de novidades em suas ofertas (produtos/serviços) e nas formas como criam e lançam essas ofertas. (TIDD; BESSANT; PAVITT, 2008, p. 25).
\end{abstract}

Com esta colocação sobre a importância da inovação nas organizações, Tidd, Bessant e Pavitt (2008) conseguiram abranger as inovações de produto (bens ou serviços) e de processo, além de mostrar que as empresas podem obter vantagem estratégica pela inovação. Estes autores centram-se em quatro categorias ou tipos abrangentes de inovação, também chamados de "4Ps". A inovação de produto consiste em mudanças nos bens ou serviços que uma empresa oferece; a inovação de processo consiste em mudanças na forma em que os bens e serviços são criados e entregues; a inovação de posição consiste em mudanças no contexto em que os bens ou serviços são introduzidos; por fim, a inovação de paradigma propõe mudanças nos modelos mentais que orientam o que a empresa faz. Estes autores 
também enfatizam que, às vezes, a linha que distingue um tipo de inovação de outro é muito tênue, principalmente em inovações ocorridas em serviços.

Outra questão ressaltada por estes autores, e que corrobora as colocações de Davila, Epstein e Shelton (2007), é relacionada às dimensões da inovação, ou aos graus de novidade presentes em determinada mudança. "Há diferentes graus de novidade desde melhorias incrementais menores até mudanças realmente radicais que transformam a forma como vemos ou usamos as coisas" (TIDD; BESSANT; PAVITT, 2008, p. 31-32). Cada um dos "4Ps" da inovação pode ocorrer em qualquer das dimensões.

Tipos de inovação propostos por outros autores e mais focados no setor de serviços serão detalhados na seção 2.3.

\subsubsection{Modelos de Gestão da Inovação}

A gestão da inovação mostra-se extremamente importante no que tange ao aproveitamento de novas ideias que surgem dentro do contexto empresarial.

[...] a inovação é mais do que simplesmente conceber uma nova ideia; é o processo de desenvolver seu uso prático. As definições de inovação podem variar em terminologia, mas todas enfatizam a necessidade de completar os aspectos do desenvolvimento e da exploração de novo conhecimento, e não apenas sua invenção. (TIDD; BESSANT; PAVITT, 2008, p. 85).

Em organizações de menor porte, a inovação normalmente é um fato natural decorrente do insight, talento e interação de um grupo pequeno de pessoas. Mas à medida que as organizações crescem a inovação deixa de ser um fato natural, devido, em parte, à existência de departamentos compartimentados e com pouca comunicação entre si. É por isso que empresas maiores precisam de sistemas para gerir a inovação.

Sistemas de inovação são políticas, procedimentos e mecanismos de informação que se estabelecem viabilizando o processo de inovação nas organizações e entre elas. São mecanismos mediante os quais a inovação (e as demais tarefas das organizações) é concretizada. [...] Para que a inovação ocorra com sucesso, deve existir um sistema explícito estabelecido para a gestão de todas as etapas da inovação - desde o desenho, passando pela avaliação, até as recompensas. (DAVILA; EPSTEIN; SHELTON, 2007, p. 135). 
De acordo com os autores supracitados, os sistemas de inovação realizam cinco importantes funções:

a) Incrementar a eficiência do processo de inovação: o sistema precisa transformar grandes ideias em negócios comercializáveis com rapidez e com o mínimo de recursos. Essa função é especialmente importante para inovações incrementais, já que abrevia o prazo do lançamento no mercado e aumenta o retorno sobre o investimento;

b) Criar linhas de comunicação mais apropriadas dentro da empresa e com o meio externo: à medida que a equipe de inovação necessita de conhecimentos especializados de outras partes da empresa ou de parceiros externos, os sistemas facilitam o acesso no momento oportuno;

c) Possibilitar coordenação de projetos e equipes com o mínimo esforço: a coordenação pode se dar por meio de um plano para permitir trabalho paralelo de equipes em projetos, com vistas a reduzir tempo de desenvolvimento; e por meio da garantia de disponibilidade de recursos no momento em que se fazem necessários;

d) Gerar aprendizado: os sistemas estabelecem uma disciplina para gerir o conhecimento que é constantemente criado em inovação. A informação pode ser utilizada para identificar problemas e possíveis aperfeiçoamentos nos projetos atuais e futuros da organização;

e) Prover alinhamento de objetivos entre as várias partes interessadas: as pessoas em todos os níveis da organização precisam entender a estratégia da empresa e as implicações da mesma em suas operações. Para tal, é necessário um sistema que garanta a inclusão de todos e a consistência das mensagens vindas do comando executivo.

O processo de inovação proposto por Davila, Epstein e Shelton está representado na figura 2. O processo se inicia com uma grande quantidade de ideias que são criadas e apreciadas, escolhidas e refinadas, até que as melhores sejam levadas à comercialização. Os sistemas são responsáveis por gerenciar todo este fluxo. Embora possa parecer que os estágios progridam linearmente, na realidade eles se superpõem e passam por várias iterações. 


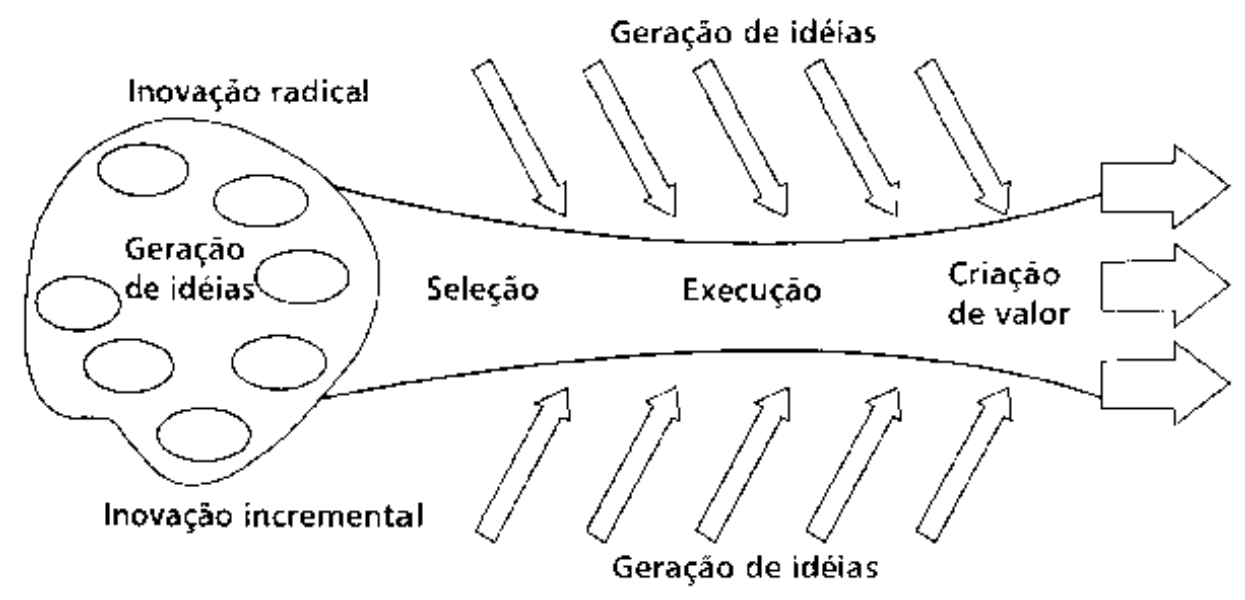

Figura 2 - O processo de inovação

Fonte: Davila, Epstein e Shelton (2007)

Nesse contexto, analisando a inovação de uma forma genérica, ou seja, vista como um processo necessário a todas as organizações, Tidd, Bessant e Pavitt (2008) formularam o seguinte processo de inovação, que tende a ser comum a todas as empresas, tanto para fornecedoras de bens quanto de serviços:

a) Procura: análise do cenário interno e externo à procura de ameaças e oportunidades para mudança. O potencial para a mudança pode se apresentar sob a forma de novas oportunidades tecnológicas, necessidades de mudança impostas pelo mercado, pressões políticas ou de concorrentes. É importante, para a gestão eficaz da inovação, que haja mecanismos bem desenvolvidos para a identificação de informações relevantes;

b) Seleção: com base nas definições estratégicas da empresa, decidir quais serão as oportunidades e ameaças priorizadas para pronta resposta;

c) Implementação: tradução do potencial da ideia inicial em algo novo, que seja lançado em um mercado interno ou externo. Neste ponto do processo, especial atenção deve ser dada à aquisição de conhecimentos; execução do projeto em meio à imprevisibilidade do ambiente; lançamento da inovação no mercado; sustentabilidade da inovação no longo prazo; e aprendizagem.

Dentro da fase de implementação, a aquisição de conhecimentos envolve a combinação entre conhecimento existente e novo para oferecer uma solução ao problema. O resultado desse estágio tanto pode ser progredir para um próximo estágio de maior detalhamento, quanto retroagir ao estágio conceitual, podendo, inclusive, ser abandonado. 
A execução corresponde à fase de desenvolvimento do projeto de inovação. Exige forte gerenciamento e integração da equipe de desenvolvimento e das dificuldades previstas e imprevistas no projeto.

A fase de lançamento visa preparar o mercado, interno ou externo, em que o produto será lançado, bem como a criação do marketing do produto, ou uma cuidadosa gestão da mudança - esta última no caso de inovação interna.

As fases de sustentabilidade e aprendizagem se complementam. Um conceito que as define bem é o da reinovação, em que uma próxima inovação baseia-se em um sucesso anterior, mas melhorando a nova geração com aspectos revisados e aprimorados. Porém, nem sempre as empresas se utilizam de lições aprendidas anteriores para conceber inovações futuras.

Este processo completo está representado na figura 3.

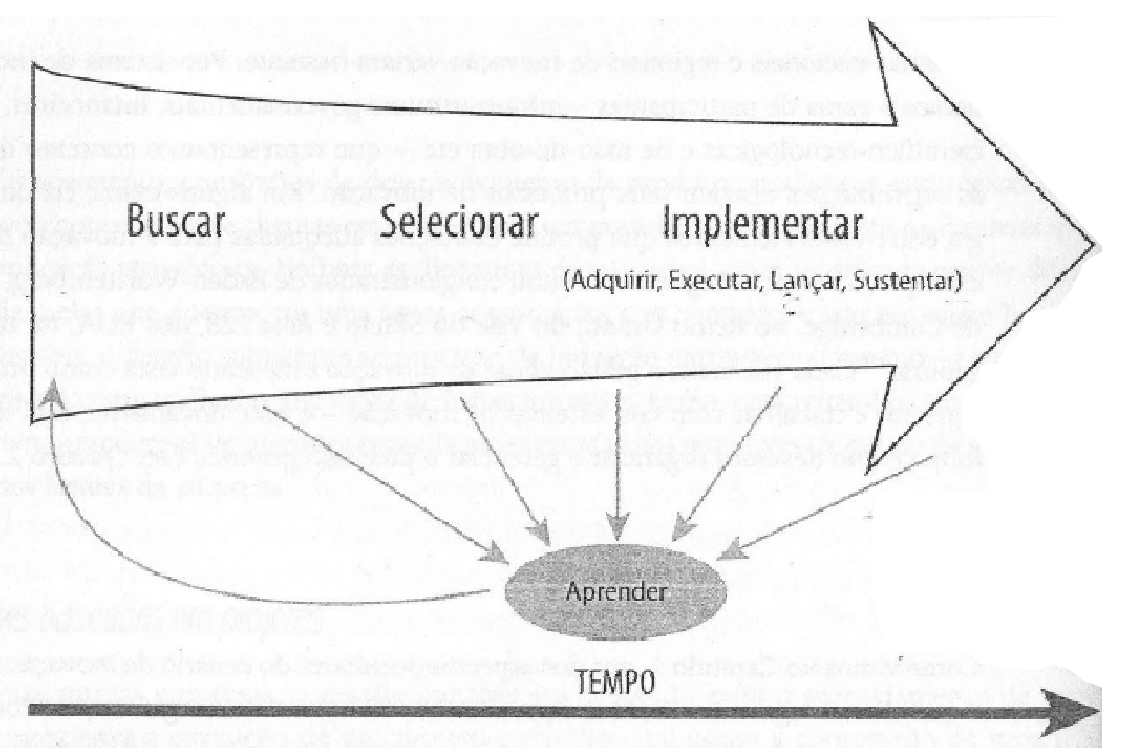

Figura 3 - Representação do processo de inovação Fonte: Tidd, Bessant e Pavitt (2008)

Esses mesmos autores acreditam que, apesar de o processo de inovação ser genérico, a gestão da inovação é uma capacidade aprendida, em que cada empresa deve encontrar sua própria solução e desenvolvê-la dentro de seu próprio contexto, não sendo suficiente apenas copiar as ideias dos concorrentes.

Diversos fatores diferenciam a forma como se dá o processo de inovação nas empresas, como ramo de atuação e porte, porém destaca-se a necessidade de levar 
em conta o grau de novidade de uma inovação, ou seja, sua classificação em incremental ou radical. Logo, dependendo do grau da inovação, haverá mais ênfase em uma determinada fase do processo em detrimento das demais, fazendo com que as empresas precisem desenvolver a capacidade de gerenciar os dois tipos de inovação em diferentes momentos.

Por sua vez, Rothwell (1994) expõe uma perspectiva histórica das várias gerações do processo de inovação, processo este que foi evoluindo de acordo com as mudanças no ambiente econômico e empresarial. Na 1ª Geração, ocorrida entre a década de 1950 e metade da de 1960, o foco do processo de inovação era basicamente em estimular e desenvolver o P\&D internamente nas empresas e aplicar os projetos no mercado (Figura 4).

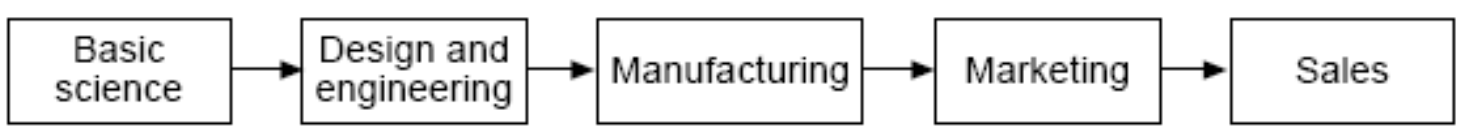

Figura 4 - Technology Push (First Generation) Fonte: Rothwell (1994)

Durante a 2ª Geração - segunda metade da década de 1960 até início de 1970 - viveu-se um momento de competição intensa, e o foco dos investimentos migrou de novos produtos e mudança tecnológica expansionista para uma mudança tecnológica mais racionalizada. Isso foi acompanhado de um crescimento das estratégias de marketing, visto que as empresas começavam a lutar por marketshare. O resultado foi um modelo de inovação em que o mercado era a fonte de ideias para direcionar o P\&D, o qual tinha uma participação meramente reativa no processo (Figura 5).

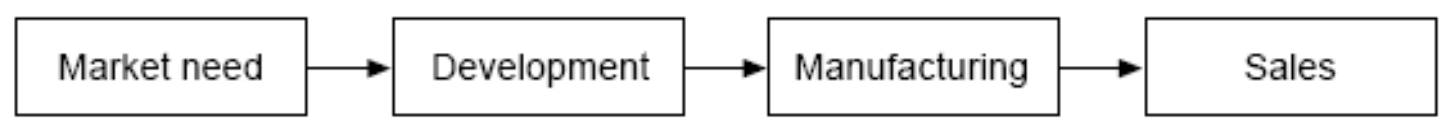

Figura 5 - Market Pull (Second Generation) Fonte: Rothwell (1994)

Tidd, Bessant e Pavitt (2008) reconhecem as limitações desses dois tipos de abordagens do processo expostos por Rothwell: não havia até então, nas duas gerações, a interação; as inovações surgiam ou por impulsos tecnológicos - em que 
novas oportunidades surgidas como fruto de P\&D acabavam por encontrar seu caminho até o mercado - ou por influxo da necessidade - em que a necessidade se torna a mãe da invenção.

A 3ª Geração - início de 1970 ao início 1980 - pode ser considerada aquela em que, pela primeira vez, um processo de inovação de sucesso foi modelado. $O$ Coupling Model, apresentado na Figura 6, é um processo que forma uma rede integrada de comunicação, tanto entre agentes internos quanto com agentes externos à empresa, fazendo a conexão desta com a comunidade tecnológicocientífica e com o mercado consumidor. Este modelo reconhece a interação entre diferentes elementos e constante feedback entre os mesmos.

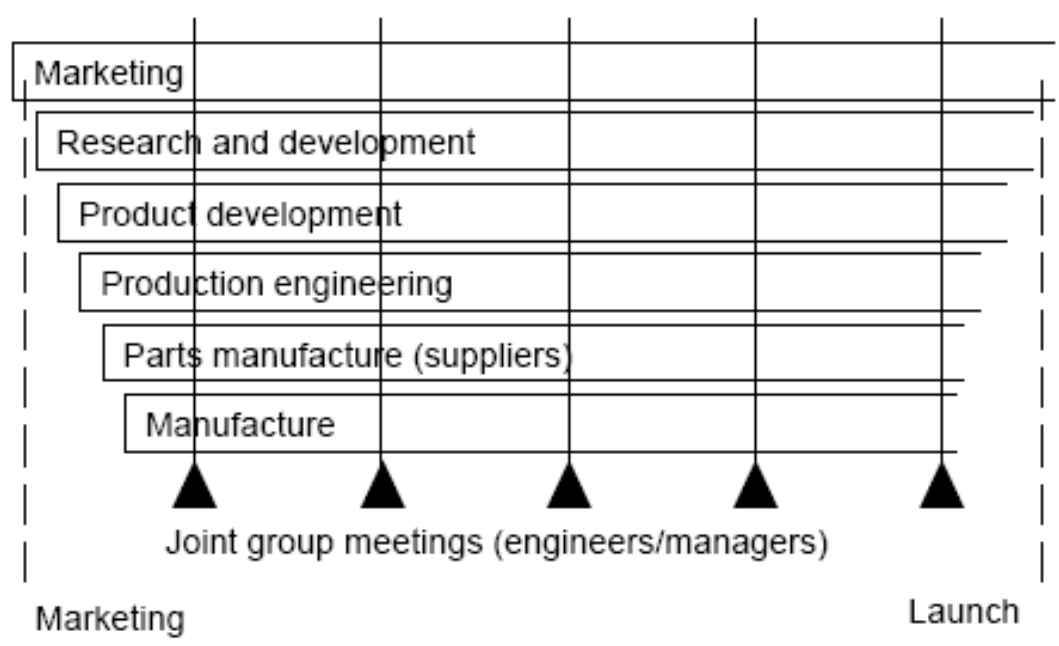

Figura 6 - The "Coupling" Model of Innovation (Third Generation) Fonte: Rothwell (1994)

A partir daí, o crescimento do networking e de alianças estratégicas entre empresas desencadeou na 4⿳a Geração (início de 1980 ao início de 1990), com um processo de inovação integrado - no sentido de envolver fornecedores e outros departamentos no desenvolvimento de produtos - e simultâneo - no que tange à disposição destes agentes em atividades paralelas dentro do processo (Figura 7). 


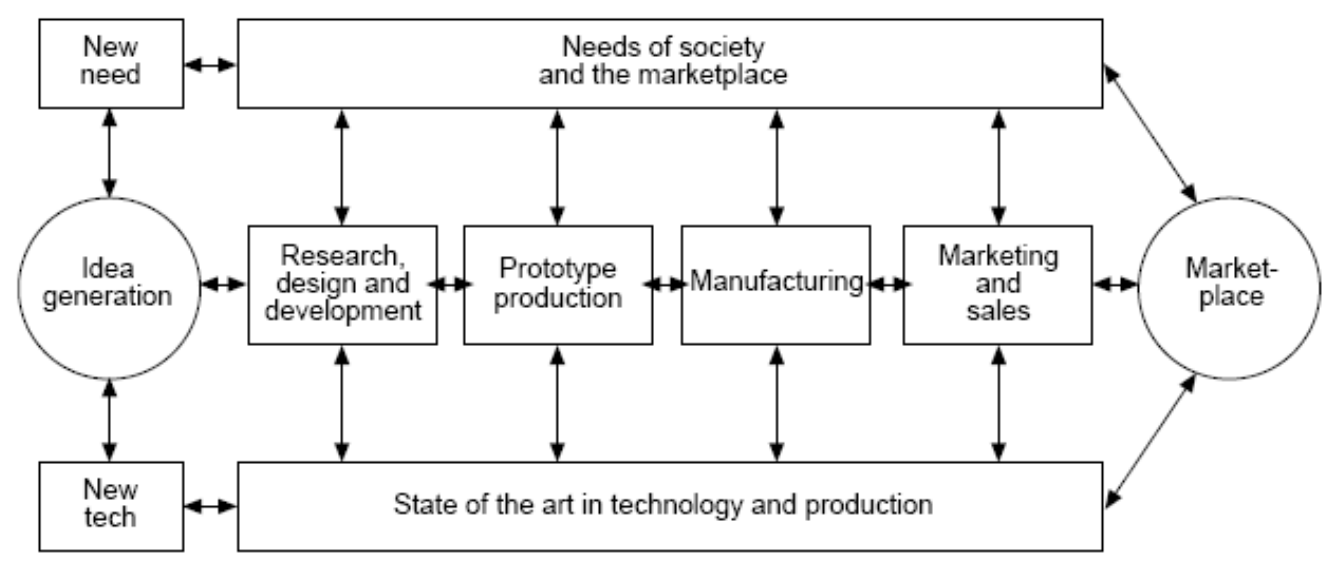

Figura 7 - Example of the Integrated Innovation Process (Fourth Generation) Fonte: Rothwell (1994)

Por fim, a 5a Geração de Rothwell, ainda aplicável aos dias atuais, enfatiza a integração de sistemas, networking abrangente e relações customizadas e flexíveis. Esta geração também ressalta a importância de inovações contínuas e velozes, sem, porém, que haja aumentos de custos decorrentes delas. A inovação nessa geração é vista como um processo que possui vários fatores responsáveis pelo aumento da velocidade da inovação com custos reduzidos. O processo exige altos níveis de integração, tanto intra como intercorporativos, e é crescentemente fomentado pelo trabalho em rede baseado na Tecnologia da Informação (TI).

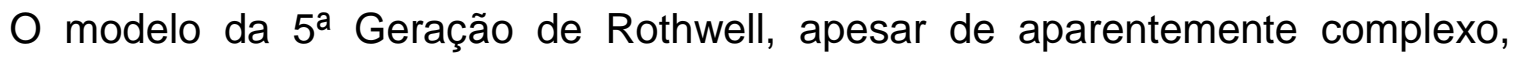
envolve a mesma estrutura básica do processo de inovação proposto por Tidd, Bessant e Pavitt (Figura 3).

Um complemento ao modelo de Tidd, Bessant e Pavitt é representado no Guide to Technology Management and Innovation for Companies (Temaguide) (COTEC, 1998 apud CORAL; OGLIARI; ABREU, 2009), que é um guia para a gestão da inovação nas empresas. Nele os elementos essenciais para a inovação são:

a) Monitoramento: observar o ambiente interno e externo procurando por sinais de oportunidades de inovação. Os sinais podem ser vários, como mudanças na legislação e novos comportamentos dos consumidores;

b) Focalização: selecionar, dentre as alternativas de desenvolvimento, a que oferecerá maior chance de vantagem competitiva;

c) Alocação de recursos: adquirir os conhecimentos explícitos e/ou tácitos necessários para desenvolver a alternativa selecionada; 
d) Implementação: desenvolver a alternativa selecionada e lançar o produto ou serviço no mercado, ou executar o novo processo na organização;

e) Aprendizado: internalizar os conhecimentos das experiências de sucessos e insucessos durante o processo de inovação.

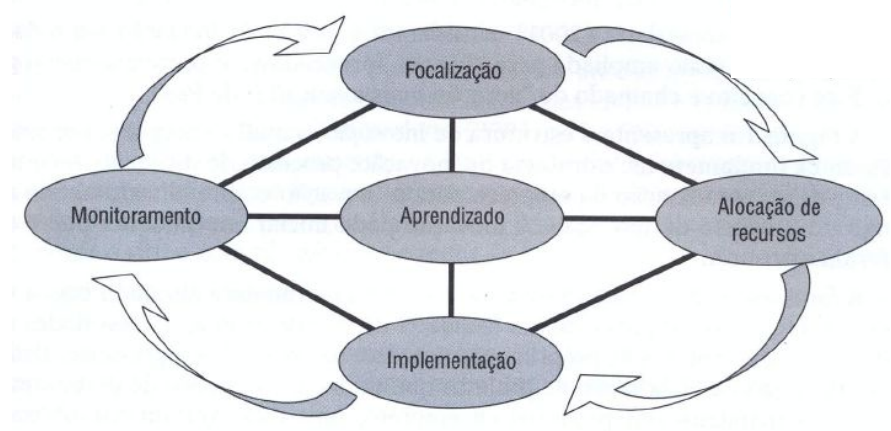

Figura 8 - Elementos essenciais do processo de inovação Fonte: COTEC (1998 apud CORAL, OGLIARI e ABREU, 2009)

Neste modelo de gestão, a inovação pode começar em qualquer ponto do processo, ou seja, não há uma sequência de atividades definida.

Por fim, os estudos sobre modelos de gestão da inovação resultaram em certas diretrizes que podem auxiliar as empresas a determinar a sua forma ideal de gerir a inovação. A primeira diretriz é que o processo de inovação não deve ser ocasional, e deve estar integrado aos demais processos da empresa. Além disso, deve ser formalizado, porém favorecendo a criatividade dos profissionais. O processo também deve estar alinhado à estratégia empresarial e faz-se necessário feedback e interação entre suas diversas fases (CORAL; OGLIARI; ABREU, 2009). 


\subsection{Serviço}

\subsubsection{O Setor de Serviços - Definições e Características}

É possível encontrar, na literatura tradicional e moderna, diversas formas de se definir e classificar os serviços. Os conceitos para essa atividade foram e vêm sendo aprimorados no decorrer da evolução econômica mundial, como afirma Kon:

As transformações e os aperfeiçoamentos nas conceituações encontradas
[para as atividades de serviços] resultam da própria evolução econômica
mundial, embasada particularmente pelas constantes mudanças
tecnológicas que levam essas atividades a papéis diferenciados no contexto
da dinâmica econômica de desenvolvimento dos países. (KON, 2004, p.
04).

Assim sendo, para melhor compreensão, será aqui exposta uma análise cronológica com as visões de diversos autores sobre o setor.

As primeiras discussões da literatura sobre os conceitos de serviços basearamse em formulações sobre o caráter produtivo ou não dessas ocupações. Os fisiocratas foram os primeiros cientistas econômicos a escrever sobre o tema, no século XVII.

Os fisiocratas divulgavam a ideia de que o trabalho agrícola era o único produtivo, sendo a terra a exclusiva fonte de riquezas, ou seja, o único fator de produção a obedecer a uma ordem natural e essencial das sociedades humanas. Apenas o solo (agricultura e mineração) era produtivo. As atividades de manufatura e as demais eram consideradas 'estéreis', não por serem dispensáveis, mas pelo fato de somente os trabalhos diretos com a natureza criarem novas formas adicionais de riqueza [...]. (KON, 2004, p. 03).

Assim, reduziam os cidadãos de uma nação em três classes: a classe produtiva, a dos proprietários e a classe estéril, em que essa última seria formada pelos cidadãos ocupados em outros trabalhos que não a agricultura.

Por sua vez, a Economia Política Clássica, buscando entender e descrever o sistema capitalista e as formas de acumulação de riqueza, voltou-se para a distinção entre atividades produtivas e improdutivas. Os clássicos reconhecem a contribuição das atividades terciárias ao produto gerado pela economia; apesar do avanço, negam explicitamente seu caráter "produtivo". Para eles, uma atividade produtiva 
seria responsável pela criação de utilidades permanentes, seja incorporada em seres humanos, ou em quaisquer outros objetos animados ou inanimados. Adam Smith ampliou o conceito da distribuição produtiva das atividades humanas, passando a compreender a atividade manufatureira como produtiva, tal qual a agrícola, ficando reservado somente aos serviços o caráter de improdutivo:

Existe uma espécie de trabalho que acrescenta valor à matéria em que é
empregado: existe outra que não tem esse efeito. A primeira, à medida que
produz valor, pode ser chamada produtiva; a última, de trabalho
improdutivo. Assim, o trabalho de um fabricante acrescenta, geralmente, ao
valor dos materiais com que ele trabalha, o valor de sua própria
manutenção e do lucro de seu patrão. O trabalho de um empregado
doméstico, ao contrário, não acrescenta valor algum. (SMITH, 1952 apud
KON, 2004, p.5).

Com relação às classificações das atividades de serviços, o termo "terciário" é um dos rótulos mais comuns encontrados sobre o setor no contexto da industrialização, em paralelo à construção dos termos "primário" e "secundário" para se referir, respectivamente, aos setores agropecuário e manufatureiro. Na mente das pessoas, à época, os serviços eram posicionados como atividades econômicas de menor relevância ou de terceiro grau de importância.

Nos estudos de Jean Baptiste Say (1983 apud KON, 2004, p. 9-10) o conceito de produção intangível e não facilmente mensurável, características das atividades terciárias, começa a se delinear com mais clareza. Aparecem em seu discurso as primeiras preocupações com os relacionamentos entre os diversos setores produtivos da economia, bem como a característica de complementaridade e dinamismo que algumas atividades terciárias exercem sobre os demais setores econômicos. A partir daí, os estudos posteriores sobre serviços passam gradativamente a valorizar esse setor como uma atividade produtiva e útil à economia.

$\mathrm{Na}$ atualidade defende-se que a utilidade contida nos serviços - em sua maior parte composta pelo desenvolvimento de ideias - pode ser estocada e acumulada em bens, fitas magnéticas, vídeos etc., fazendo com que a intangibilidade de seu produto deixe de ser um fator de relevância inferior. Essa utilidade é tida hoje como grande fonte de valor no mercado, fazendo com que a conceituação das atividades de serviços ganhe nova dimensão. Portanto, nas economias modernas, todos os produtos, tangíveis ou intangíveis, desempenham papel econômico semelhante, passando a utilidade a ser a meta final de toda atividade produtiva. 
Autores da fase pós-industrial criticam as definições até então vigentes, pois eles consideram que as características atribuídas às indústrias de serviços intangibilidade, intensidade em trabalho, simultaneidade de produção e consumo e perecibilidade - são também relevantes para todas as demais atividades econômicas, com exceção da intangibilidade. Ademais, consideram que alguns serviços podem ser semiduráveis ou duráveis e não perecíveis, características antes utilizadas somente para os bens.

T. P. Hill, cujo conceito de serviços é consideravelmente divulgado, o define de forma bastante acurada:

Um serviço pode ser definido como uma mudança na condição de uma pessoa ou de um bem pertencente a um agente econômico, que vem à baila como resultado da atividade de outro agente econômico, por acordo prévio, ou seja, solicitação da pessoa ou agente econômico anteriores. (HILL, 1977, p. 315 apud GADREY, 2001, p.31).

A contribuição de Hill (1977 apud KON, 2004, p. 27) também pode ser notada quando afirma que as peculiaridades dos bens e dos serviços não podem ser determinadas pela tecnologia empregada - a qual pode ser a mesma para a produção e para a reparação de um bem -, ou pela diferença de durabilidade - os serviços poderem ser considerados, em certos casos, permanentes ou irreversíveis, assim como os produtos -, ou pela transportabilidade - serviços também podem ser transportados, como é o caso de um software gravado em CD. Observações desse tipo reforçam que as definições tradicionais de serviços e de manufatura estão se tornando obsoletas, já que são observáveis nas economias modernas diferentes combinações de trabalho entre as áreas de produção e serviços.

De acordo com Gadrey (2001), a definição de Hill acima apresentada ainda está distante da materialidade, da "armazenabilidade" ou da "perecibilidade" do produto. Segundo ele, o que Hill descreve é uma relação social de serviço com o intuito de realizar uma "mudança de condição" solicitada por um agente econômico (cliente ou consumidor) detentor da realidade a transformar, que recorre, para isso, a outro agente econômico (prestador de serviço ou produtor). O produto (do serviço), então, é a mudança de estado da realidade submetida à intervenção. Baseando-se na definição de Hill, Gadrey especifica serviço com uma definição a qual chama de "triângulo do serviço": 
[...] uma atividade de serviço é uma operação que visa uma transformação do estado de uma realidade $C$, possuída ou utilizada por um consumidor $B$, realizada por um prestador de serviços $A$ a pedido de $B$, e com frequência relacionada a ele, não chegando porém à produção de um bem que possa circular economicamente independente do suporte C. (GADREY, 2001, p. 32).

Contrapondo as definições expostas, é perceptível que a grande diferença entre elas reside na precisão com que se determina, na segunda, que o resultado do serviço "não possa circular economicamente independente do suporte de C", excluindo-se definitivamente da definição dos serviços a atividade produtiva, ainda presente na definição de Hill. Porém, é possível observar que ambas as definições não comportam a extrema diversidade do campo de atuação constituído pelas atividades de serviços. Percebendo isso, Gadrey (2001) aprimora sua definição, concluindo que "há produção econômica de serviços nos sistemas capitalistas desenvolvidos nos dois casos seguintes":

a) Quando uma organização $A$, que possui ou controla uma capacidade técnica e humana, vende para um agente econômico B o direito de uso dessa capacidade e dessas competências por um período determinado;

b) Quando uma família ou um consumidor final emprega um assalariado para cuidar de seus bens ou de si mesmo ou eventualmente de pessoas diante das quais o empregado exerce uma função delegada de responsabilidade.

Gadrey (2001) faz, ainda, outra importante distinção, voltada para a realidade dos países desenvolvidos. Ele separa os serviços em dois grupos do ponto de vista da diversidade por eles apresentada:

a) Um grupo de serviços cuja participação no emprego cresce pouco ou permanece estacionária: distribuição, transportes, correios, telecomunicações, bancos e seguros, administrações públicas centrais;

b) Um grupo de serviços cuja participação no emprego progrediu nitidamente: empresas, saúde, alimentação, turismo, educação, ação social, associações, coletividades locais.

Existe um princípio fundamental das atividades de serviço que afirma que os serviços presentes nesse último grupo apresentado por Gadrey são atividades que envolvem relacionamentos, significando a presença, na própria produção do serviço, de um componente essencial: as relações de serviço, isto é, interações de 
informação e verbais, contatos diretos e trocas interpessoais entre produtores e beneficiários. Este princípio é notável nas exposições de outros autores apresentados neste estudo.

Em relação a isso, Grönroos (1993) salienta que as interações entre clientes e fornecedores fazem parte dos serviços e são de substancial importância: o cliente avalia o trabalho feito pelo fornecedor, mesmo que inconscientemente, com base nas interações que ocorrem entre eles durante o processo de desenvolvimento do serviço. O mesmo autor traz, ainda, uma visão até então pouco explorada neste estudo: ele lembra que o aspecto da heterogeneidade é também uma característica básica dos serviços. Ou seja, devido ao impacto das pessoas - funcionários ou clientes - no processo de produção, um serviço a um cliente não corresponde exatamente a este mesmo serviço ao próximo cliente.

Marshall (1988, apud KON, 2004, p. 26) salienta que, ainda nos anos 90, o debate sobre a classificação dos serviços divide-se em duas abordagens. A abordagem convencional aceita o setor de serviços como um grupo de atividades distinto da manufatura, cujo crescimento acarreta uma mudança significativa na economia moderna. Por outro lado, a visão alternativa enfatiza que ainda permanece uma interdependência entre certos serviços e as tendências industriais passadas.

Dentro de uma ótica de abordagem envolvendo exemplos bastante contemporâneos, Kon propõe a seguinte definição para os serviços:

[...] é possível definir serviços como atividades econômicas que produzem utilidades relativas a tempo, lugar, forma e benefícios psicológicos. Para exemplificar, o serviço doméstico por um profissional pode economizar o tempo de quem o contrata e que está engajado em outro tipo de trabalho. As lojas de departamentos fornecem bens reunidos em um local mais facilmente utilizado pelo consumidor. Os serviços de informática colocam ao dispor do consumidor uma série de informações de uma maneira a ser mais utilizável. Uma peça de teatro oferece os benefícios psicológicos de entretenimento. Assim, as atividades de serviços tanto facilitam a produção e a distribuição de bens quanto atendem as necessidades da vida pessoal dos indivíduos. (KON, 2004, p. 26).

As discussões mais recentes ressaltam que a importância de definir e classificar os serviços não está em distingui-los dos bens, mas em verificar as funções que desempenham na economia. Neste contexto, Gershuny e Miles (1983 apud KON, 2004, p. 29) ampliaram o âmbito de atuação dos serviços ao observar que uma mesma função pode ser desempenhada por diferentes produtos - como a função de comunicação, que pode ser exercida pelos produtos representados por cartas, fax, 
internet. Esse enfoque resume o sentido de que os produtos finais de um sistema econômico são todos serviços: os bens e serviços comprados pelos consumidores são usados para produzir funções-serviço, como diversão, transporte etc.

Conhecidas as diversas conceituações de serviços existentes, mostra-se necessária a escolha de uma definição de serviços a ser seguida neste estudo. Sendo assim, considera-se como base para o trabalho o conceito do "triângulo do serviço" (GADREY, 2001), já mencionado nesta seção, por ser um conceito recente e vastamente aceito.

\subsubsection{Os Serviços no Brasil}

A abordagem que caracteriza a atividade de serviços como residual - atividade econômica além da agricultura e da manufatura, ou uma parcela pouco significativa que resta de um todo - está longe de ser considerada verdadeira, já que os serviços representam, na maior parte das economias desenvolvidas e em desenvolvimento, o maior dos três setores econômicos.

No Brasil, a partir dos anos 50, a participação dos serviços no emprego total (assalariado e não assalariado) passou de $24 \%$ em 1950, a 31\% em 1970, e a 57\% em 1996, segundo Gadrey (2001). Durante esse mesmo período, o setor primário passava de $59 \%$ em 1950, a $50 \%$ em 1970 , e a $23 \%$ em 1996; e o setor secundário passava de $17 \%$ em 1950, a $18,5 \%$ em 1970 , e a $20 \%$ em 1996, conforme pode ser observado no Gráfico 1.

É notório o aumento da participação dos serviços na economia de outros países neste período, além do Brasil. 


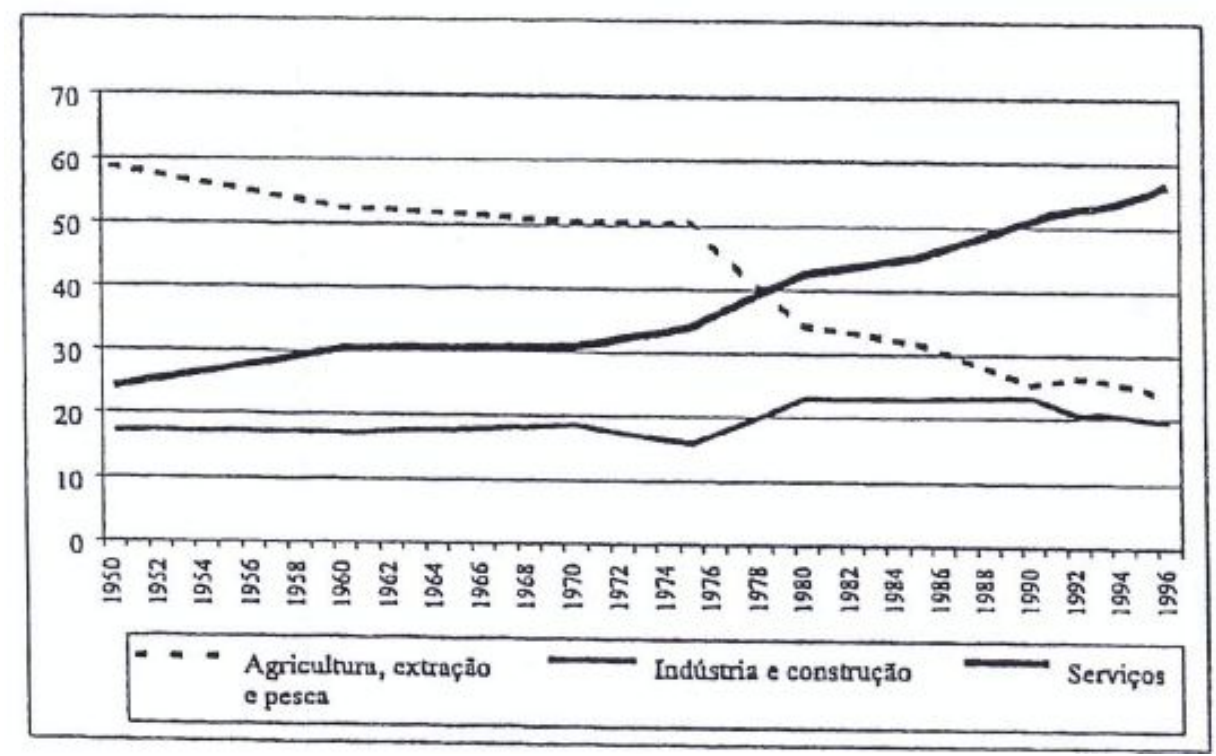

Gráfico 1 - Participação de cada um dos três setores no emprego total no Brasil (1950-1996): Agricultura, extração e pesca; Indústria e construção; e Serviços

Fonte: Gadrey (2001)

Com base em dados presentes na Pesquisa Anual de Serviços (PAS) (IBGE, 2007), podemos analisar informações ainda mais recentes sobre os serviços no Brasil. A PAS tem como objetivo apresentar a estrutura produtiva do setor de serviços não financeiros no Brasil. Conforme a pesquisa, em 2003 os serviços não financeiros - serviços prestados às famílias; serviços de informação; serviços prestados às empresas; serviços de transportes; atividades imobiliárias e de aluguel de bens móveis e imóveis; serviços de manutenção e reparação; e outras atividades de serviços - ocupavam 6,4 milhões de pessoas, pagando $R$ \$ 61 bilhões em salários, retiradas e outras remunerações. O salário médio era de 3,2 saláriosmínimos mensais, e os dispêndios com pessoal representavam $51,8 \%$ do valor adicionado nas atividades do setor. Já em 2007, passados apenas três anos, havia 8,7 bilhões de pessoas ocupadas nos serviços, compondo uma massa salarial de $\mathrm{R} \$$ 106,8 bilhões. Em média, o setor pagou 2,5 salários-mínimos. O total dos gastos com pessoal representou $47,4 \%$ do valor adicionado dos serviços.

Em adição, pode-se observar o crescimento do valor agregado - Produto Interno Bruto (PIB) - do Brasil em volume nos três grandes setores, de 1950 a 1995 (Gráfico 2). 


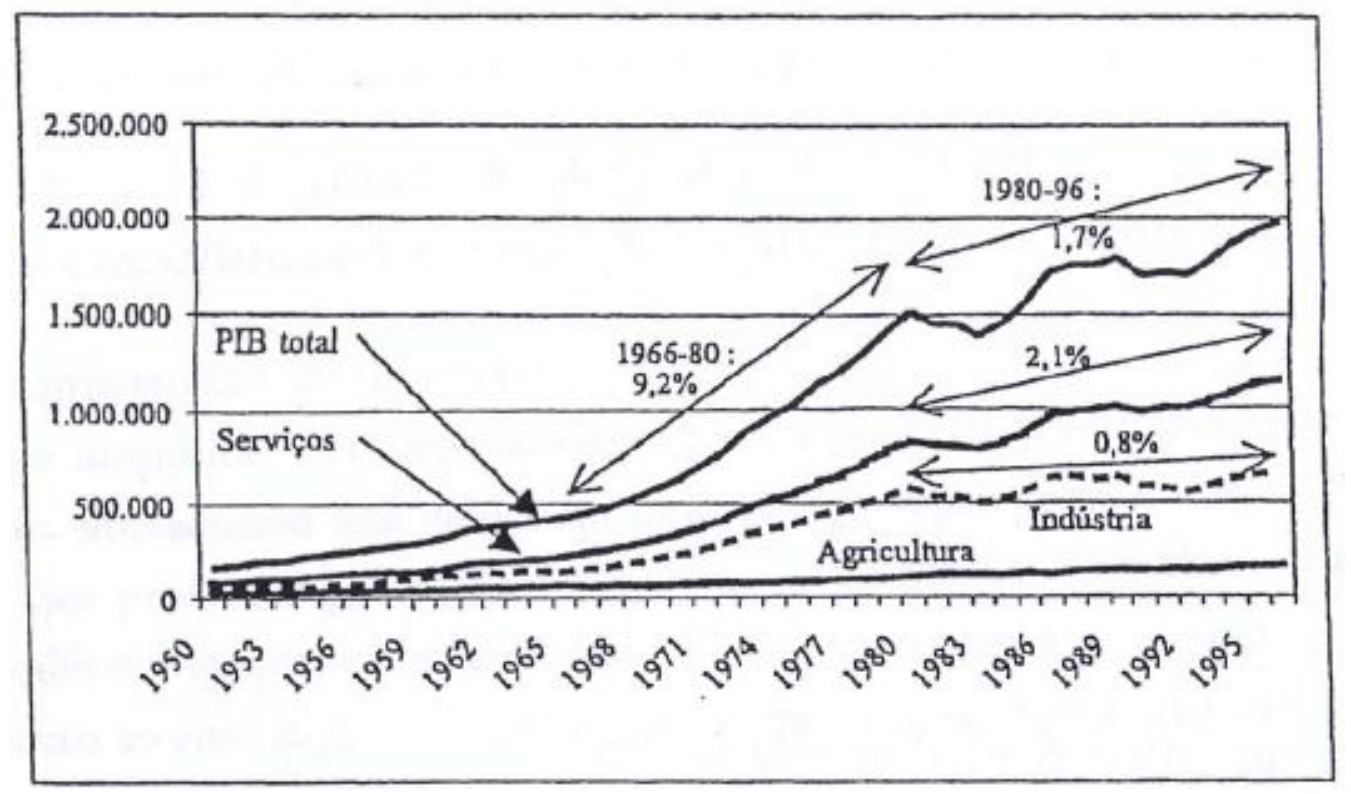

Gráfico 2 - PIB do Brasil por grandes setores - em preços de 1975 (milhões de cruzeiros) Fonte: Gadrey (2001)

Fica visível que, a partir de 1980, o crescimento econômico reduziu-se muito, e que essa desaceleração foi sensivelmente mais notória na indústria do que nos serviços, o único setor a, timidamente, puxar a expansão.

De fato, os serviços representam mais de $70 \%$ da riqueza e do emprego na maioria dos países desenvolvidos. A dinâmica desse setor, seja qual for a perspectiva de análise escolhida (inovação, criação de empregos, a medição das performances, a organização espacial etc.), ainda está longe de ser bem conhecida teoricamente e de ser operacionalmente dominada (que se trate de administração de empresa ou de política pública). (GALLOUJ, 2007, p. 3).

Sendo assim, apesar de cada vez mais presente na economia, o serviço é ainda uma atividade de difícil conceituação, como já exposto em 2.2.1.

Em dados mais recentes relacionados ao PIB, a publicação Sistemas de Contas Nacionais (IBGE, 2007) apresenta uma síntese do desempenho da economia brasileira no ano de 2007. Sob a ótica da produção, que mede a contribuição das atividades para geração do valor adicionado bruto, houve crescimento de $6,1 \%$ do PIB em relação a 2006, que foi decorrente de um acréscimo de 6,1\% dos serviços, $5,3 \%$ da indústria e 4,8\% da agropecuária.

Em 2007, analisando o desempenho das atividades que constituem o grupo Serviços no Sistema de Contas Nacionais, 60\% das atividades de serviços que compõem este grupo registraram variações em volume superiores às verificadas no 
ano de 2006. Estes resultados garantiram o crescimento, em volume, do valor adicionado dos Serviços de 6,1\% em 2007. A atividade com a mais alta variação em volume foi a de serviços de intermediação financeira, seguros e previdência complementar e serviços relacionados (15,1\%). A seguir, destacam-se os serviços de manutenção e reparação que apresentaram um crescimento em volume de 8,9\%. Educação mercantil, com variação anual em volume de $0,9 \%$, e administração pública e seguridade social, com 3,3\%, foram as atividades com as menores variações positivas. Ressalta-se, ainda, o comportamento das atividades de serviços domésticos $(-0,9 \%)$ e de educação pública $(-3,3 \%)$ como as únicas a registrarem taxas negativas no ano.

\subsection{Inovação em Serviços}

A inovação por muitos anos foi estudada no setor de manufatura, e foi nestas bases que as teorias foram criadas. Partindo-se do fato de que a manufatura produz bens enquanto os serviços produzem itens imateriais, surge o questionamento de se as empresas de serviços também inovam e, em caso afirmativo, como ocorre este processo. Segundo Tidd, Bessant e Pavitt (2008, p. 24), "evidentemente, a inovação não está restrita a bens manufaturados; exemplos de reviravolta pela inovação podem ser encontrados no setor de serviços [...]".

A dificuldade de criação de uma definição precisa do conceito de serviços tópico já abordado na seção 2.2 - traz consigo certas limitações, como o fato de a economia contemporânea - que é, ao mesmo tempo, economia de serviços e economia de inovação - não ser vista como economia de inovação nos serviços. Gallouj (2007, p. 4) interpreta esse paradoxo afirmando que "tudo se passa como se os serviços e a inovação constituíssem dois universos paralelos, que coexistem ignorando-se."

Alguns mitos antigos justificam esta subestimação da inovação nos serviços. Um deles é a concepção de serviços como atividade improdutiva, desprovida de valor econômico, visão esta em que as atividades de serviços, diferentemente daquelas de manufatura, se dissipam no instante de sua realização. Um segundo mito é o que veicula a ideia de que o terciário seria um setor caracterizado por baixa intensidade 
de capital e baixa produtividade, devido à ausência de fábricas e de linhas de produção nestas atividades. Há, ainda, o mito que ataca a capacidade do setor de serviços de gerar empregos, qualidade que, na realidade, pode ser considerada um ponto forte do setor. A inverdade desses mitos foi observada na seção 2.2, sendo a apresentação de resultados da Pesquisa Anual de Serviços uma das comprovações.

Segundo Hipp e Grupp (2005), existem critérios que ajudam a distinguir a forma como ocorrem os processos de inovação em serviços dos processos em manufatura. Um desses critérios é o fator humano: a inovação em serviços não pode ser identificada apenas de forma tecnológica; ela é definida também por habilidades como conhecimento organizacional, experiência dos funcionários e proximidade com os consumidores. Outro fator importante nos serviços é a organização do processo de inovação, que passa a depender mais de métodos de venda e marketing do que do desenvolvimento de tecnologias em si. Além disso, esses autores apontam ser difícil distinguir as inovações que ocorrem no processo das inovações que ocorrem no produto do serviço, já que muitas vezes a produção e o consumo são simultâneos.

Sundbo (1997) salienta que a inovação em serviços ocorre de forma não sistemática, mas há um esforço crescente das empresas para sistematizar e gerir esta inovação, mesmo com a constatação de que são poucas as empresas de serviços que possuem um departamento de P\&D ou um departamento específico para gerir a inovação. Sundbo (1997) apresenta em seus estudos três modelos da inovação voltados para a manufatura e refuta a possibilidade de adoção de dois deles - Modelo Tecnológico-econômico e Modelo Empreendedor - para entender a inovação em serviços. Já o terceiro modelo é considerado mais adequado para explicar e compreender a inovação no setor de serviços.

O modelo proposto é chamado de Modelo de Inovação Estratégica, visto que enfatiza a estratégia da empresa como a essência para o modelo de inovação. Nele, as inovações são orientadas para o mercado e baseiam-se integralmente na estratégia empresarial adotada, garantindo a convergência de ações. Os gestores da empresa são os responsáveis por controlar o processo de inovação, mas ideias de inovações provêm de todas as partes da organização e também do meio externo. Nesse modelo, o processo de inovação ocorre da seguinte forma: 
a) Geração de ideias: ideias vêm de diferentes indivíduos da organização, que as coletam dos clientes, jornais e outros meios. A participação maior dos funcionários é nesta etapa. É um processo criativo; logo, as ideias não podem ser geradas sobre comando, devendo surgir naturalmente;

b) Transformação em um projeto de inovação: a pessoa que vislumbrou uma oportunidade persuade pessoas de poder da organização a dar prosseguimento à ideia. Neste ponto, então, os gestores definem se este projeto será aprovado ou não;

c) Desenvolvimento: aprovada a ideia, é estabelecido um grupo de desenvolvimento de um protótipo, sendo inclusive estudada sua viabilidade mercadológica: a ideia precisa ser colocada no mercado, verificando-se sua aceitação para futura implementação;

d) Implementação: neste momento os gestores decidem se o protótipo será implementado como um novo produto, novo processo ou outra forma de inovação. Um departamento relacionado à inovação se encarrega desta fase.

A ressalva de Sundbo (1997) é de que o processo de inovação descrito acima não ocorre linearmente; é, pelo contrário, bastante complexo e caótico, assim como o processo de inovação exposto por Davila, Epstein e Shelton (2007), apresentado em 2.1.2. Há, ainda, contínuo contato e envolvimento dos clientes e demais stakeholders da organização, sendo o envolvimento dos clientes na inovação ainda mais importante em empresas de serviços do que em manufaturas. É possível analisar a convergência deste modelo também com o modelo da Terceira Geração da Inovação - The Coupling Model - proposto por Rothwell (1997) e explicitado em 2.1.2 (Figura 6), o qual é também orientado para o mercado e enfatiza a importância das redes de relacionamento internas e externas.

Assim como Sundbo (1997), partindo também da premissa das especificidades existentes nos serviços, Gallouj e Weinstein (1997 apud GALLOUJ, 2007) consideram que um produto (bem ou serviço) pode ser representado por um conjunto de vetores de características e competências colocados em correspondência (Figura 9). 


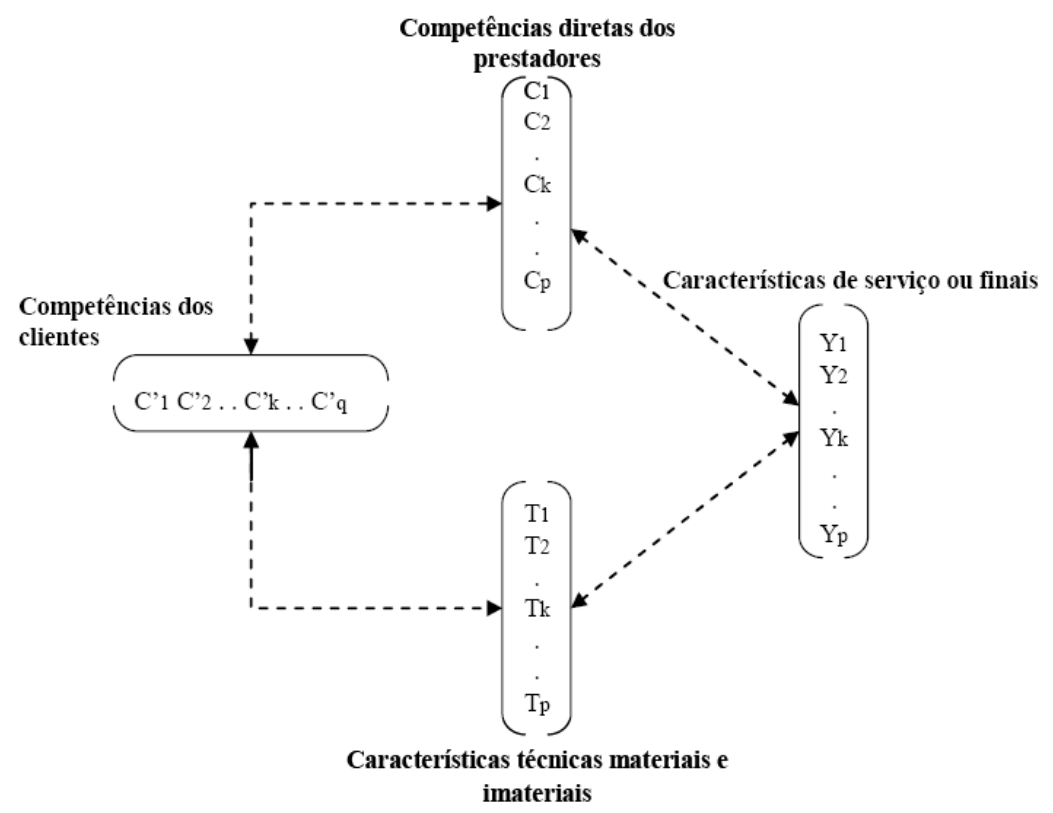

Figura 9 - O produto como vetores de características e de competências colocados em correspondência

Fonte: Gallouj e Weinstein (1997 apud GALLOUJ, 2007)

Neste modelo, as competências [C] e [C'] derivam de diversas fontes: formação inicial, treinamento contínuo, experiência, interação. As características técnicas [T] dos serviços geralmente tomam a forma de habilidades e conhecimentos presentes nos indivíduos (ou equipes) ou guardados de forma escrita (por meio de manuais, instruções, etc), e que são utilizadas no momento da execução do serviço. As características técnicas imateriais (ou intangíveis) são competências formalizadas e codificadas. Porém, são independentes dos indivíduos que as criaram e constituem a memória organizacional.

Com base no modelo da Figura 9, uma prestação de serviços pode ser definida como "a mobilização simultânea de características técnicas (materiais e imateriais) e de competências (internas e externas) para produzir características de serviços." E a inovação pode, então, ser definida como "toda mudança afetando um ou vários termos dos vetores de características (técnicas, de serviço) ou de competência." (GALLOUJ, 2007, p. 14). Dessa forma, a inovação não é encarada como um resultado, mas como um processo ou um modelo que descreve dinâmicas particulares de características e competências.

Em outra publicação, Gallouj (2002) complementa que uma especificidade das atividades de serviços é que o produto $[\mathrm{Y}]$ de determinado serviço pode surgir sem a necessidade de adição de características materiais. Ou seja, os conhecimentos e 
competências dos indivíduos, [C] e [C’], podem, sozinhos, criar um produto final. A Figura 10 mostra um caso particular da Figura 9, mostrando o formato de um serviço puro, intangível. Nesta configuração, a habilidade de gerar um serviço [Y] depende crucialmente da habilidade de organizar diferentes competências. Esta representação é observada nos serviços baseados em conhecimento, tais como consultorias.

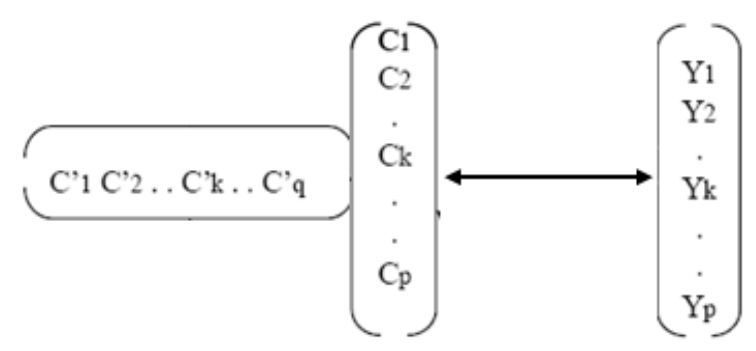

Figura 10 - O caso de um serviço puro, intangível Fonte: Gallouj (2002)

Gallouj $(2002,2007)$ propõe, ainda, com base na representação mostrada na Figura 9, uma forma de caracterizar diferentes inovações por meio de seis tipos ou modelos que, em sua análise, têm a vantagem de eliminar a distinção das inovações entre, simplesmente, radical e não radical, que é a forma como os tipos de inovações são difundidos por outros autores. Abaixo estão identificados os modelos propostos por Gallouj:

a) Inovação radical. Descreve a criação de um produto totalmente novo, que é um conjunto de novas características e competências $-\left[\mathrm{C}^{* *}\right],\left[\mathrm{C}^{\star}\right],\left[\mathrm{T}^{\star}\right],\left[\mathrm{Y}^{\star}\right]$. Em outras palavras, o novo produto, as características e as competências que o produziram são diferentes daquelas do produto antigo. É importante perceber que as competências dos clientes [C'] também são renovadas, já que, quanto mais radical é a inovação, mais necessário é que o cliente aprenda a utilizá-la. A inovação radical também pode ser aplicada àquelas inovações que substituem todos os vetores [C'], [C] e [T], mas mantêm as mesmas características finais do serviço [Y];

b) Inovação pela melhoria. Outros tipos de inovação propostos compartilham o objetivo de melhorar o produto final. Mas a diferença da inovação pela melhoria para as demais é que ela consiste em elevar a qualidade das características do produto sem trocar a estrutura do sistema, ou seja, 
mantendo [C'], [C], $[\mathrm{T}]$ e $[\mathrm{Y}]$, que apenas sofrerão acréscimos de qualidade. Este tipo de inovação é resultado dos efeitos de aprendizagem que normalmente acompanham qualquer atividade;

c) Inovação incremental. Este tipo de inovação também descreve uma melhoria no produto; no entanto, há adição ou eliminação de características. Assim, estrutura geral do sistema - $\left[\mathrm{C}^{\prime}\right],[\mathrm{C}],[\mathrm{T}]$ e $[\mathrm{Y}]$ - se mantém, mas o sistema é modificado marginalmente através da substituição ou adição de novos elementos ao vetor das características $[T]$ ou ao vetor dos serviços $[Y]$. Assim, a diferença entre a inovação incremental e a inovação pela melhoria é que, na primeira, novas características são adicionadas e, na segunda, uma simples melhoria é feita;

d) Inovação ad hoc. Pode ser definida como a construção interativa de uma solução para um problema particular de determinado cliente. Este tipo de inovação é comumente produzido em conjunto entre o prestador do serviço e o cliente. $\mathrm{O}$ resultado final $[\mathrm{Y}]$ de uma inovação ad hoc pode ser entendido como uma solução original que surge em resposta a um problema novo. Do ponto de vista do prestador de serviços, a inovação ad hoc ajuda a produzir novos conhecimentos e competências, que precisam ser codificadas e formalizadas para serem reutilizadas em outras circunstâncias. Assim, corresponde a uma mudança significativa em [C] e nos elementos imateriais de $[T]$;

e) Inovação pela recombinação. Baseia-se na divisão ou reutilização de características existentes para a criação de um novo produto [Y]. Pode acontecer também por meio da reutilização de características de dois ou mais produtos diferentes para a criação de um terceiro; ou pela criação de novos produtos dividindo um produto existente, separando várias de suas características em produtos autônomos. A inovação incremental pode ser considerada uma forma particular de inovação pela recombinação, quando as características adicionadas provêm de produtos preexistentes;

f) Inovação pela formalização. Neste modelo, não são as quantidades e qualidades das características e competências que variam; o que muda é o grau de padronização dos elementos dos vetores. Este modelo consiste em organizar e especificar as características e competências do serviço, fazendo 
com que elas sejam menos nebulosas e mais concretas, e atribuindo ao serviço certo grau de materialidade. Exemplos de inovação pela formalização são mapeamentos de processos, matrizes etc. 


\subsection{Serviços de Software}

\subsubsection{O Setor de Softwares no Brasil}

O setor de softwares e as inovações dele decorrentes vêm se tornando cada vez mais presentes na economia do Brasil e dos demais países.

O crescimento econômico se manifesta cada vez mais associado à introdução de inovações tecnológicas inerentes à Tecnologia da Informação (TI), que está rapidamente reestruturando as formas de competir em praticamente todos os setores produtivos. (SOUSA, 2004, p. 2).

O conceito de software, de acordo com Sousa (2004, p. 2), significa "uma sequência lógica de instruções que coordenam a operação de um processador com função e comportamento definidos". O software exige, para a sua construção, um projeto de engenharia que será implementado conforme especificação definida pelo usuário ou cliente.

A história da indústria de software teve sua origem por volta de 1960. Antes, porém, ele era considerado parte integrante do hardware, não havendo comercialização daquele como componente distinto das máquinas: o hardware era comercializado juntamente com o software e o preço era estabelecido sobre o conjunto da solução. Entretanto, em certo momento, ficou evidente que o desenvolvimento de software envolvia custos que, em alguns casos, chegavam a superar o custo do hardware. Esse aspecto foi decisivo para que se iniciasse um movimento de apropriação de valor comercial ao software, desmembrando-o do valor inerente ao hardware (SOUSA, 2004).

O nascimento da indústria de software ocorre, então, nos Estados Unidos em função das demandas geradas por projetos estratégicos do governo. De um modo geral, todos os organismos governamentais dos Estados Unidos, em suas diferentes esferas, contam com generosos orçamentos para a área de Tecnologia da Informação e razoável independência para administrá-los. E a inovação no setor de software não é apenas aceita, mas largamente estimulada por parte do governo americano. 
No Brasil, ao contrário, é comum ouvir do governo insinuações de que as empresas de $\mathrm{TI}$ locais não têm condições de atender suas demandas, ou mesmo que não oferecem as funcionalidades já disponíveis em um software desenvolvido no exterior e que não é possível esperar para que tais funcionalidades sejam aqui desenvolvidas.

Apesar de as associações empresariais defenderem, já há muitos anos, que o governo brasileiro utilize seu poder de compra em favor das empresas brasileiras de base tecnológica, a regra estabelecida sempre foi a de contratação de multinacionais, que tomam conta de todos os aspectos de $\mathrm{TI}$, num movimento contínuo de diminuição do espaço ocupado pelas empresas de software que têm sua matriz no Brasil (CÂMARA DOS DEPUTADOS, 2007).

Uma mostra disso é a disparidade na balança comercial de software brasileira, que evidencia que o país ainda se mantém como potencial importador (Tabela 1).

Tabela 1 - Balança Comercial Brasileira de Software (US\$ milhões)

\begin{tabular}{c|c|c|c}
\hline CATEGORIAS & $\mathbf{1 9 9 0}$ & $\mathbf{1 9 9 5}$ & $\mathbf{2 0 0 0}$ \\
\hline Importação de Software & 50 & 200 & 1.200 \\
\hline Exportação de Software & 1 & 10 & 100 \\
\hline Balança Comercial & -49 & -190 & -1.100 \\
\hline
\end{tabular}

Fonte: Pagani (2002 apud SOUSA, 2004)

Estudos internacionais apontam a existência de cerca de dez mil empresas brasileiras de informática. Segundo dados da Associação Brasileira das Empresas de Tecnologia da Informação (Assespro) (2001 apud CÂMARA DOS DEPUTADOS, 2007), porém, há no Brasil cerca de 27 mil empresas de informática, das quais cerca de 4.200 declaram dedicar-se ao desenvolvimento de software. De acordo com dados do Instituto Brasileiro de Geografia e Estatística (IBGE) (2001 apud CÂMARA DOS DEPUTADOS, 2007) do mesmo ano, há cerca de 38 mil empresas de informática, empregando 220 mil pessoas. Os dados das receitas das empresas do setor sugerem que se trata de um mercado em que as empresas médias e grandes desempenham papel primordial. 
Tabela 2 - Atividades de Informática ( $R$ \$ milhões)

\begin{tabular}{c|c|c|c}
\hline \multicolumn{4}{c}{ Atividades de Informática: Receitas das Empresas } \\
\hline Porte & Serviços & Revenda & Outras \\
\hline Até 5 empregados & 1.725 & 32 & 102 \\
\hline 6 a 19 empregados & 795 & 52 & 67 \\
\hline 20 a 99 empregados & 3.177 & 100 & 220 \\
\hline $\begin{array}{c}\text { 100 empregados ou } \\
\text { mais }\end{array}$ & 10.522 & 1.790 & 962 \\
\hline Total & $\mathbf{1 6 . 2 1 9}$ & $\mathbf{1 . 9 7 4}$ & $\mathbf{1 . 3 5 1}$ \\
\hline
\end{tabular}

Fonte: IBGE (2003 apud SOUSA, 2004)

Nota-se que empresas com mais de 100 empregados auferem cerca de 65\% das receitas de serviços, onde o software se inclui, $91 \%$ das receitas de revenda de mercadorias e $71 \%$ das demais receitas.

Desde 1993, a Secretaria de Política de Informática do Ministério da Ciência e Tecnologia (Sepin) desenvolve uma pesquisa objetiva junto às empresas de software, denominada Qualidade e Produtividade no Setor de Software Brasileiro. O objetivo dessa pesquisa é acompanhar a evolução da gestão da qualidade do setor, para servir de apoio às ações dos agentes que formulam e executam a política de software para o país. Mostra quais organizações atuam no setor e que tipo de software é desenvolvido no Brasil, bem como o perfil das pessoas que trabalham nessas empresas, as práticas de gestão e como é o processo de software e de ciclo de vida do produto.

A pesquisa realizada em 2004 com 707 empresas de todo o Brasil obteve algumas informações relevantes sobre o setor. A primeira delas diz respeito ao início das atividades das empresas de TI. Como mostrado no Gráfico 3, as empresas pesquisadas são bastante jovens: cerca de 70\% ainda não completaram 15 anos de vida. 


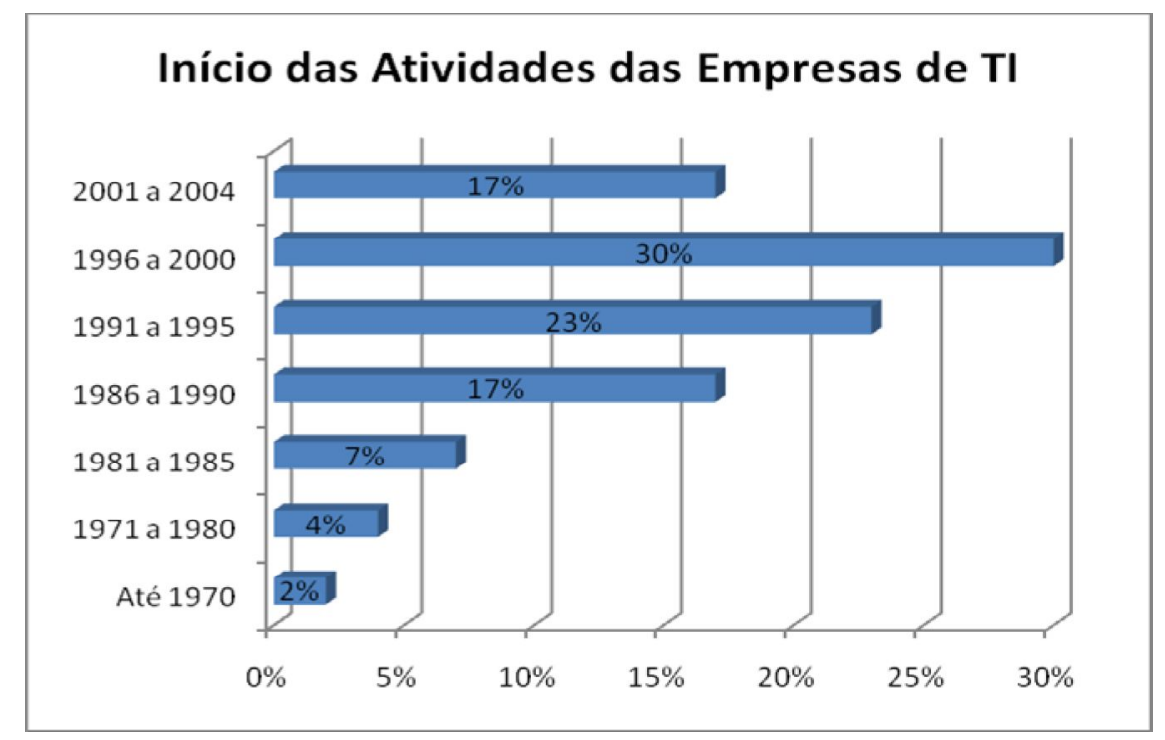

Gráfico 3 - Início das Atividades das Empresas de TI

Fonte: Sepin (2005) - Pesquisa Qualidade e Produtividade no Setor de Software Brasileiro

O perfil das empresas pesquisadas, mostrado no Gráfico 4, é basicamente de micro e pequenas empresas, que somam $77 \%$ da amostra. É interessante destacar que $45 \%$ das empresas têm menos de 10 pessoas trabalhando.

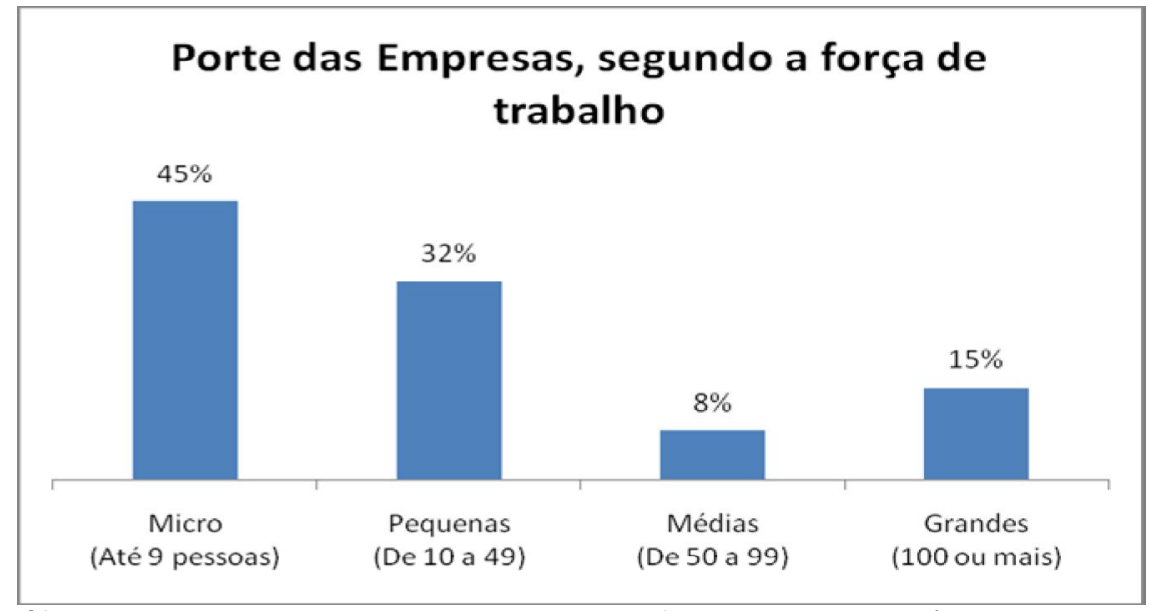

Gráfico 4 - Porte das Empresas, segundo a força de trabalho (adaptado pela autora) Fonte: Sepin (2005) - Porte das Empresas, segundo a força de trabalho

A força de trabalho efetiva - que tem carteira e contrato de trabalho assinado - é muito pequena nessas empresas. A terceirização no setor é forte e a tendência se mantém desde as primeiras pesquisas realizadas pela Sepin. Isso ocorre porque a empresa ganha porte e reduz custos de folha de pagamentos com a força de trabalho terceirizada, formada por terceiros, bolsistas e estagiários. Uma comprovação do peso dos gastos trabalhistas nos custos pode ser observada na 
Tabela 3. Em relação à carga tributária, apesar de o Brasil manter baixas as taxas incidentes sobre o percentual de faturamento, os elevados encargos trabalhistas (102\%) ainda dificultam a expansão da indústria, fazendo com que algumas empresas optem por formas alternativas de contratação de mão-de-obra.

Tabela 3 - Comparativo de Tributação de Software - 2002

\begin{tabular}{c|c|c}
\hline País & $\begin{array}{c}\text { Tributações } \\
\text { (\% sobre faturamento) }\end{array}$ & $\begin{array}{c}\text { Encargos } \\
\text { (\% sobre folha) }\end{array}$ \\
\hline Brasil & 19,4 & 102 \\
\hline EUA & 43,0 & 11 \\
\hline Alemanha & 23,7 & 38 \\
\hline Argentina & 34,6 & 40 \\
\hline
\end{tabular}

Fonte: Pagani (2002 apud SOUSA, 2004) ${ }^{1}$

Em relação às principais áreas de atuação das empresas de software presentes no estudo da Sepin, o Gráfico 5 mostra percentualmente o número de empresas que exercem estas atividades, sendo que uma empresa pode atuar em um ou mais focos. No ranking apresentado, um terço delas trabalha com o desenvolvimento de softwares voltados para automação comercial, enquanto oito tipos de atuações diferentes são tratados por mais de $20 \%$ das empresas pesquisadas.

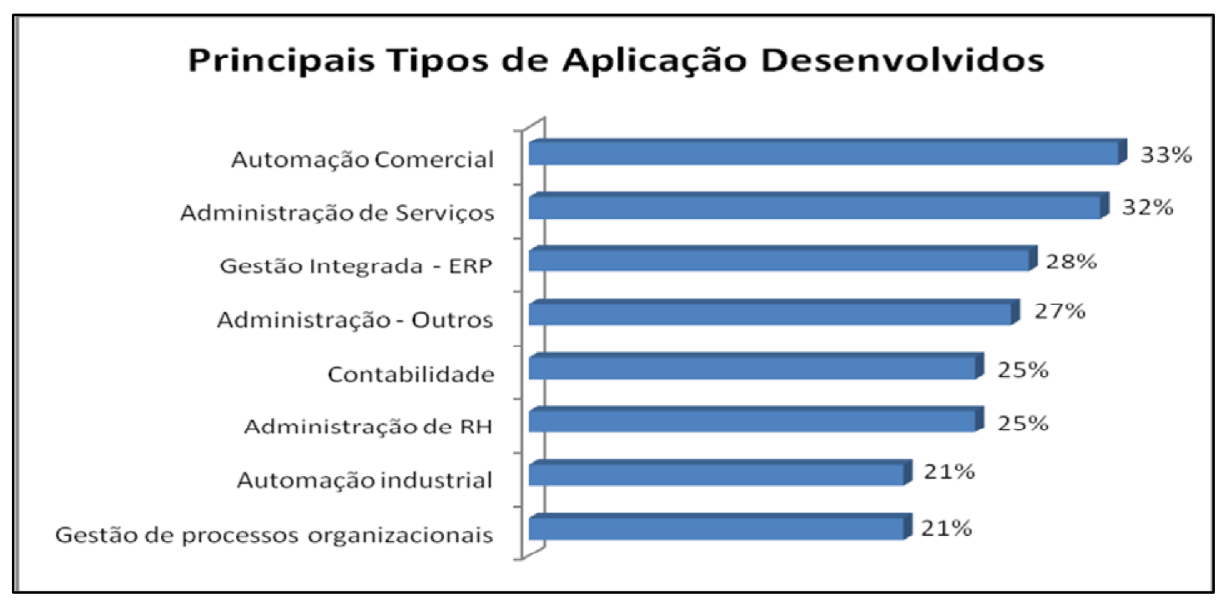

Gráfico 5 - Principais tipos de aplicação desenvolvidos

Fonte: Sepin (2005) - Pesquisa Qualidade e Produtividade no Setor de Software Brasileiro

\footnotetext{
1 São considerados como encargos todos os valores excedentes ao valor do salário contratado e que foram desembolsados em função da contratação de funcionários. Por isso, admite-se valores superiores a 100.
} 
Conhecido o conceito de software e as características do setor, faz-se necessário discorrer especificamente sobre os serviços de software.

Os serviços de software compreendem serviços de capacitação, manutenção, suporte ou desenvolvimento completo de um software sob encomenda. (SEBRAE, 2007 apud MOREIRA, 2009). No caso específico da atividade de desenvolvimento de serviços de software, marcada pela concepção de uma solução voltada a um cliente específico, vem à tona a característica da heterogeneidade proposta por Grönroos (1993) para classificar os serviços, em que, mesmo com um produto vendido sob mesmo escopo de trabalho a dois diferentes clientes, o serviço prestado a um não corresponde exatamente a este mesmo serviço prestado ao outro cliente.

Steinmueller (1995, apud MOREIRA, 2009) diferencia software enquanto produto e enquanto serviço também com foco na produção individual, afirmando que um software que é produzido somente uma vez deve ser visto como um input de serviço, enquanto um programa que é reproduzido várias vezes tem características mais próximas às de bens manufaturados.

No ano de 2007, o IBGE realizou a Pesquisa Anual de Serviços, na qual uma das atividades de serviços analisada foi a de Serviços de Informação, composta por empresas de Telecomunicações; Atividades de informática; Serviços Audiovisuais; e Agências de notícias e serviços de jornalismo.

Conforme o Gráfico 6, as Atividades de Informática, onde se encontram as empresas prestadoras de serviços de software, apresentam a maior porcentagem de participação no que tange a salários, pessoal ocupado e número de empresas. Em 2007, esta atividade totalizou 82,5\% (58.627) das empresas dos Serviços de informação, 62,5\% do pessoal ocupado (367.619) e pagou 55,1\% ( $\mathrm{R} \$ 9,2$ bilhões) dos salários, retiradas e outras remunerações. As empresas de informática geraram, em 2007, $\mathrm{R} \$ 38,5$ bilhões de receita operacional líquida (23,8\% do total). Estes fatores evidenciam a importância da atividade. 


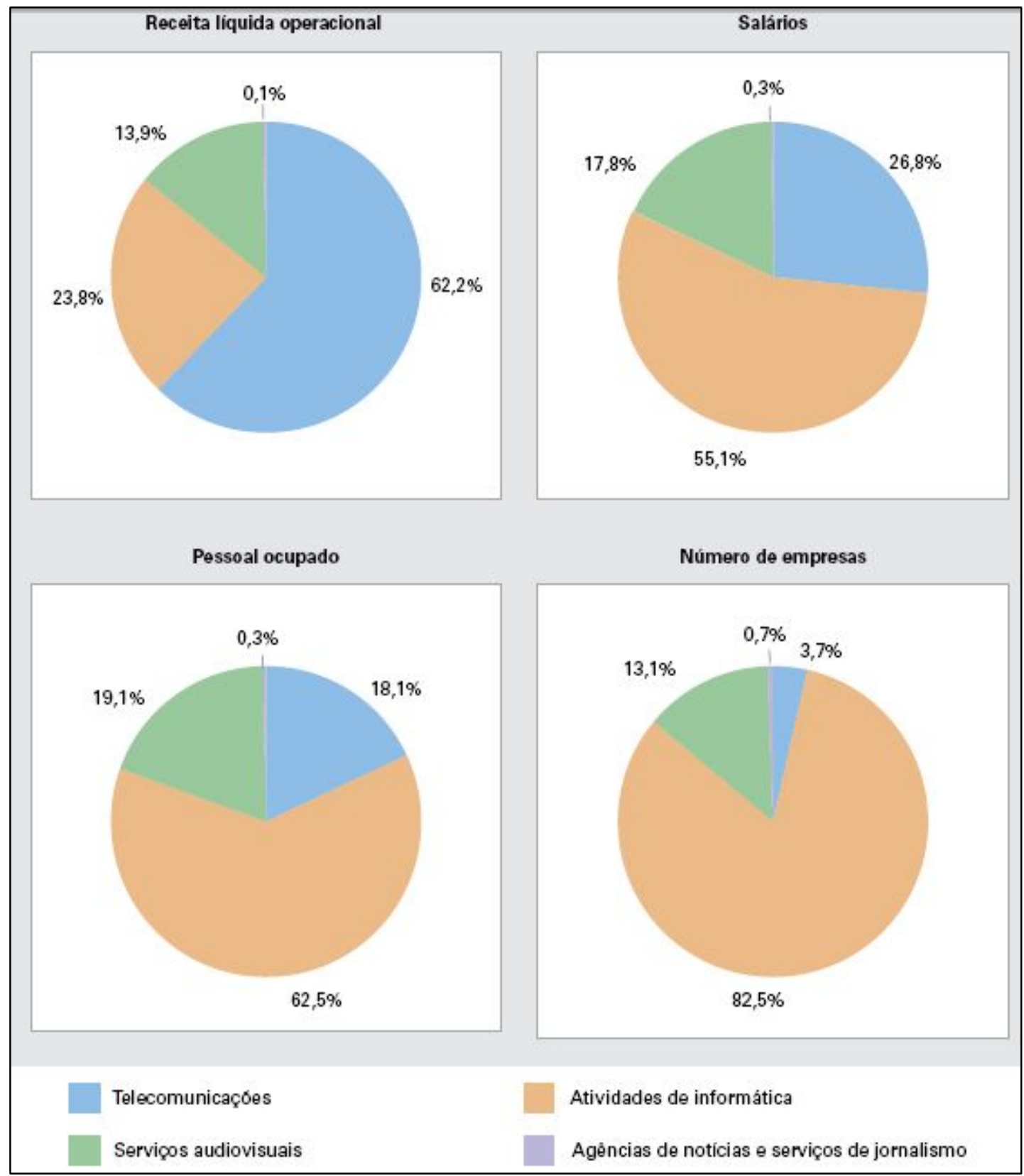

Gráfico 6 - Participação das atividades no segmento de serviços de informação (Brasil - 2007) Fonte: IBGE (2007), Diretoria de Pesquisas, Coordenação de Serviços e Comércio, Pesquisa Anual de Serviços.

Segundo dados de 2009 da Associação Brasileira das Empresas de Software (ABES), em 2008, apesar das turbulências econômicas ocorridas no ano, o mercado brasileiro de software e serviços ocupou a $12^{\underline{a}}$ posição no cenário mundial, tendo subido uma posição em relação a 2006 e movimentado 15 bilhões de dólares, o equivalente a $0,96 \%$ do PIB brasileiro de 2008. Desses 15 bilhões, 5 bilhões foram movimentados em software e 10 bilhões de dólares em serviços relacionados, como mostra o Gráfico 7 . 


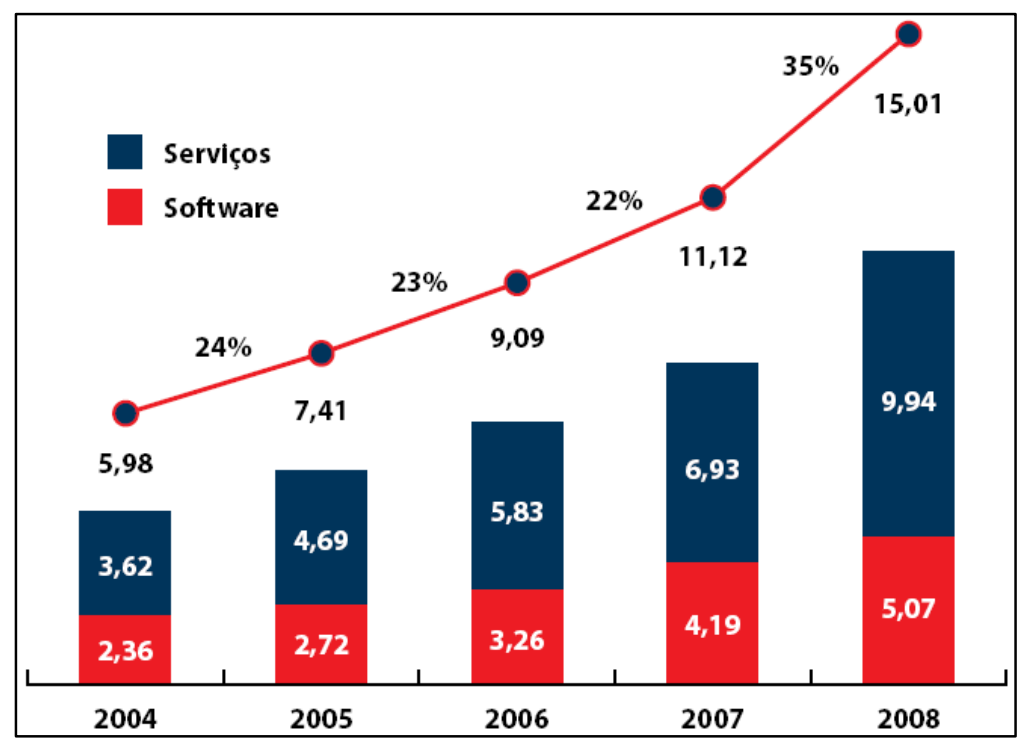

Gráfico 7 - Indicadores de Mercado e Evolução (US\$ Bilhões) Fonte: ABES (2009) - Mercado Brasileiro de Software

Ainda no ano de 2008 a participação de programas de computador desenvolvidos no país atingiu $32,5 \%$ do total do mercado brasileiro de software o que corrobora com a tendência de crescimento que vem sendo apontada desde 2004, período em que a participação era de $27 \%$.

Outro dado relevante é que este mercado de softwares e serviços relacionados é explorado por quase 8.500 empresas, dedicadas ao desenvolvimento, produção e distribuição de software e de prestação de serviços. Daquelas que atuam no desenvolvimento e produção de software, $94 \%$ são classificadas como micro e pequenas empresas (ABES, 2009).

\subsubsection{Subsídios à Inovação em Serviços de Software}

Atualmente o principal problema enfrentado pelas empresas de TI brasileiras é a falta de recursos para financiar seus projetos (informação verbal) ${ }^{2}$. Apesar disso, um dado relevante e bastante contraditório é que agentes financiadores, como a Financiadora de Estudos e Projetos (FINEP), possuem recursos - humanos, financeiros e materiais - para investimento que estão sendo subutilizados. A FINEP é o principal agente responsável pelo Programa de Subvenção Econômica, o qual

\footnotetext{
${ }^{2}$ Notícia fornecida por Eduardo Grizendi no Workshop Incentivos à Inovação para o Setor de Software, em Brasília, em maio de 2010.
} 
tem por objetivo promover um significativo aumento das atividades de inovação e o incremento da competitividade das empresas e da economia do país.

A concessão de subvenção econômica para a inovação nas empresas é um instrumento de política de governo largamente utilizado em países desenvolvidos e operado de acordo com as normas da Organização Mundial do Comércio (OMC). Lançada no Brasil em agosto de 2006, esta nova modalidade de apoio financeiro permite a aplicação de recursos públicos não-reembolsáveis diretamente em empresas, para compartilhar com elas os custos e riscos inerentes a tais atividades. O marco-regulatório que viabiliza a concessão de subvenção econômica foi estabelecido a partir da aprovação da Lei 10.973, de 02/12/2004, conhecida por Lei Federal da Inovação, e da Lei 11.196, de 21/11/2005, mais conhecida como Lei do Bem.

O artigo $1^{\circ}$ da Lei Federal da Inovação explica que esta Lei "estabelece medidas de incentivo à inovação e à pesquisa científica e tecnológica no ambiente produtivo, com vistas à capacitação e ao alcance da autonomia tecnológica e ao desenvolvimento industrial do País” (BRASIL, 2004). Porém, de acordo com 0 parágrafo $2^{\circ}$ do artigo 19 da mesma Lei, "a concessão de recursos financeiros, sob a forma de subvenção econômica, financiamento ou participação societária, visando ao desenvolvimento de produtos ou processos inovadores, será precedida de aprovação de projeto pelo órgão ou entidade concedente" (BRASIL, 2004). Portanto, as empresas precisam manter-se informadas sobre as formas de proceder com relação a estes incentivos. Tanto a Lei Federal da Inovação quanto a Lei do Bem preveem uma série de benefícios para aquelas empresas com projetos submetidos e aprovados à avaliação pelas agências de fomento, sendo boa parte deles incentivos tributários.

Há, portanto, grande oportunidade para as empresas de serviços de software brasileiras, que, seguindo parâmetros pré-estabelecidos, podem submeter seus projetos de inovação às agências financiadoras, compartilhando os riscos de cada negócio e usufruindo de benefícios que as auxiliarão em sua maior competitividade no mercado. 


\section{MÉTOdOS E TÉCNICAS DE PESQUISA}

Esta seção de propõe a apresentar os procedimentos metodológicos utilizados para a realização do presente estudo. São apresentados o tipo de pesquisa realizada, a caracterização do setor e das organizações estudadas, os participantes do estudo, os instrumentos de pesquisa e, por fim, os procedimentos de coleta e análise de dados. Para a fundamentação teórica, foram utilizados os trabalhos de Fachin (2002); Flick (2004); Gil (1996); Sampieri, Collado e Lucio (2006).

\subsection{Tipo e descrição geral da pesquisa}

O presente trabalho teve por objetivo descrever como o processo de gestão da inovação ocorre em empresas de serviços de software, com base no modelo proposto por Tidd, Bessant e Pavitt (2008), os quais subdividem este processo em três grandes fases genéricas, que são: procura de oportunidades e ameaças; seleção de ideias; e implementação da inovação; sendo que a implementação está dividida nas etapas de aquisição de conhecimentos, execução, lançamento, sustentabilidade e aprendizado. Depois de entendido o processo de gestão da inovação procurou-se definir os tipos de inovações presentes nas empresas pesquisadas, utilizando-se os tipos ou modelos propostos por Gallouj (2002, 2007): inovação radical, pela melhoria, incremental, ad hoc, pela recombinação e pela formalização.

Quanto à forma de abordagem do problema, este estudo é classificado como uma pesquisa qualitativa, já que busca o aprofundamento da compreensão de um setor empresarial específico, que é o setor de serviços de software, como estratégia para o estudo da questão de pesquisa definida. Quanto a seus objetivos, a presente pesquisa classifica-se como uma pesquisa descritiva, já que visa descrever características de um fenômeno, sendo ele o modelo de gestão da inovação seguido por cada empresa de serviços de software deste estudo. Este trabalho tem como 
estratégia de pesquisa o estudo de casos múltiplos. De acordo com Fachin (2002), este método é caracterizado por ser um estudo intensivo.

É levada em consideração, principalmente, a compreensão, como um todo, do assunto investigado. [...] O direcionamento deste método é dado na obtenção de uma descrição e compreensão completas das relações dos fatores em cada caso, sem contar o número de casos envolvidos. [...] Sua principal função é a explicação sistemática das coisas (fatos) que ocorrem no contexto social [...]. (FACHIN, 2002, p. 44-45).

Segundo Gil (1996), o primeiro procedimento em um estudo de caso consiste em delimitar a unidade que constitui o caso em estudo, podendo este ser uma pessoa, uma comunidade, uma empresa etc. Sendo assim, neste estudo, seis empresas de serviços pertencentes ao ramo de serviços de software foram selecionadas e analisadas, tendo como objetos de estudo os processos de gestão da inovação nelas desenvolvidos. Ainda Gil (1996) indica que algumas regras devem ser observadas no método do estudo de caso:

a) Buscar casos típicos: explorar objetos que pareçam ser a melhor expressão do tipo ideal de categoria.

b) Selecionar casos extremos: a vantagem desta regra é que ela pode fornecer uma ideia dos limites dentro dos quais as variáveis podem oscilar.

c) Tomar casos marginais: encontrar casos atípicos ou anormais para, por contraste, conhecer os casos normais e as possíveis causas do desvio.

A regra utilizada neste estudo é a de busca de casos típicos, já que é analisada a forma como ocorrem os processos de gestão da inovação nas empresas, procurando avaliar fatores que os enquadram nas fases do modelo teórico de Tidd, Bessant e Pavitt (2008).

Com relação à coleta de dados neste estudo de casos múltiplos, em cada empresa foi feita uma pesquisa documental, juntamente com realização de entrevista semi-estruturada, sobretudo do tipo narrativa, com informantes-chave. Sendo assim, o tratamento dos dados, ou natureza das variáveis pesquisadas, foi realizado de forma qualitativa. As informações foram coletadas com os participantes do estudo por meio de gravação e, logo após, foi feita a transcrição escrita.

$\mathrm{Na}$ etapa de análise de dados, foi utilizada a estratégia da codificação temática, com uma breve descrição de cada caso e com a criação de categorias comuns às 
respostas dos sujeitos, buscando identificar as fases e etapas dos modelos de gestão da inovação de cada empresa; além disso, foram analisadas as inovações identificadas em cada caso, de acordo com os tipos propostos por Gallouj (2002, 2007).

Com base nesses estudos aprofundados, uma análise de padrões de gestão da inovação no segmento de serviços de software pode ser identificada e replicada.

\subsection{Caracterização do setor e das organizações estudadas}

As organizações em que os dados foram coletados fazem parte das empresas de Serviços de Informática, de acordo com a classificação da Pesquisa Anual de Serviços (IBGE, 2007), mais especificamente inseridas no ramo de empresas prestadoras de serviços de softwares atuantes no Distrito Federal.

Foram selecionadas seis empresas com base no tipo de serviço que oferecem, já que a abrangência do tema e das questões investigadas implicou na necessidade de delimitação do objeto. Foram escolhidas empresas de médio e grande porte que são consideradas expoentes do setor, nas quais a possibilidade de visualização de inovações torna-se maior. A definição do número de empresas pesquisadas deveuse ao fato de que, em um estudo de casos múltiplos, o pesquisador deve ter uma base considerável e racional para fazer generalizações a partir dos dados.

As empresas analisadas serão aquelas prestadoras de serviços de software que possuem em seu portfólio serviços como: Consultoria, Integração de Sistemas, Outsourcing, Suporte, Treinamento, Data-entry, Processamento de Dados, Desenvolvimento e Manutenção de Conteúdos de Páginas da Internet e Business Process Outsourcing (BPO) (ABES, 2009).

Para a preservação do sigilo das informações fornecidas pelos entrevistados nos casos selecionados, optou-se, neste estudo, pela omissão de nomes e outras informações que possam levar à identificação dos casos, razão pela qual utiliza-se a denominação "Caso A", "Caso B", etc. 


\subsection{Participantes do estudo}

Neste estudo, o tipo de entrevista semi-estruturada utilizado é a entrevista com especialistas. Nela, há "menor interesse no entrevistado enquanto pessoa (como um todo) do que em sua capacidade de ser um especialista para um certo campo ou atividade. Ele é integrado ao estudo não como um caso único, mas representando um grupo" (FLICK, 2004, p. 104).

Os participantes entrevistados neste estudo foram funcionários de nível gerencial ou os próprios diretores ou sócios das organizações, em alguns casos de fácil acesso aos mesmos. A escolha do nível hierárquico mais elevado deveu-se ao fato de que gerentes, diretores e sócios possuem maior acesso a informações que envolvem o processo de inovação como um todo e conseguem fazem melhor associação deste com a estratégia empresarial adotada.

Devido ao número reduzido de entrevistados, reforça-se a importância de utilização de entrevista semi-estruturada, cujo roteiro de entrevista será detalhado na seção 3.4 .

\subsection{Instrumentos de pesquisa}

O roteiro de entrevista foi criado pela autora deste estudo e encontra-se disponível no Apêndice A. Como característica da entrevista semi-estruturada, as questões foram formuladas de maneira que o roteiro fosse mais considerado como um guia, no qual se espera que as questões sejam livremente respondidas pelo entrevistado. Assim, "o entrevistador pode e deve decidir, durante a entrevista, quando e em que sequência fazer quais perguntas" (FLICK, 2004, p. 106). Se uma pergunta já tiver sido respondida e puder ser omitida, isso pode ser decidido pelo entrevistador.

Foi feita uma validação do primeiro roteiro elaborado, com o intuito de verificar se ele estava realmente atingindo os objetivos a que este trabalho se propõe. A validação do roteiro foi realizada com duas empresas do setor de softwares, e o que 
se notou foi que ele possibilitava a verificação de apenas parte do processo de gestão da inovação das empresas. No roteiro inicial, as etapas de lançamento da inovação no mercado, sustentabilidade da inovação a longo prazo e aprendizado gerado não eram facilmente observadas com as perguntas existentes. As alterações foram feitas de forma a suprir a necessidade destas informações, permitindo, então, coletar o máximo de informações relacionadas às fases genéricas do processo de inovação propostas por Tidd, Bessant e Pavitt.

O roteiro de entrevista subdivide-se em quatro partes, sendo a Parte 1 e a Parte 2 compostas pela identificação do entrevistado e da empresa em estudo, respectivamente. A Parte 3 caracteriza os principais segmentos de atuação da empresa, onde poderá ser observado o público-alvo e as soluções disponíveis em seu portfólio. Por fim, a Parte 4, a de maior importância para o estudo, identifica as inovações recentes e o processo de inovação seguido pelas empresas, abrangendo informações sobre identificação e descrição das inovações; procura de oportunidades e seleção de projetos; aquisição de conhecimentos; desenvolvimento da inovação; lançamento e sustentabilidade da inovação; e o aprendizado gerado durante o processo.

Além das entrevistas, consta neste estudo a utilização de pesquisa bibliográfica, já apresentada da seção 2 , na qual foram recolhidos dados sobre o setor de software, por meio de artigos de periódicos e material disponibilizado na internet. Houve também pesquisa documental, visando obter informações específicas sobre cada uma das empresas. Esta pesquisa documental foi realizada tanto por meio de informações sobre as empresas disponíveis na internet, quanto por meio de documentos obtidos com os próprios entrevistados.

No roteiro de entrevista validado, buscou-se coletar dados organizados em torno de quatro blocos temáticos, que são apresentados no Quadro 1 e que serão utilizados para posterior descrição de cada caso. 


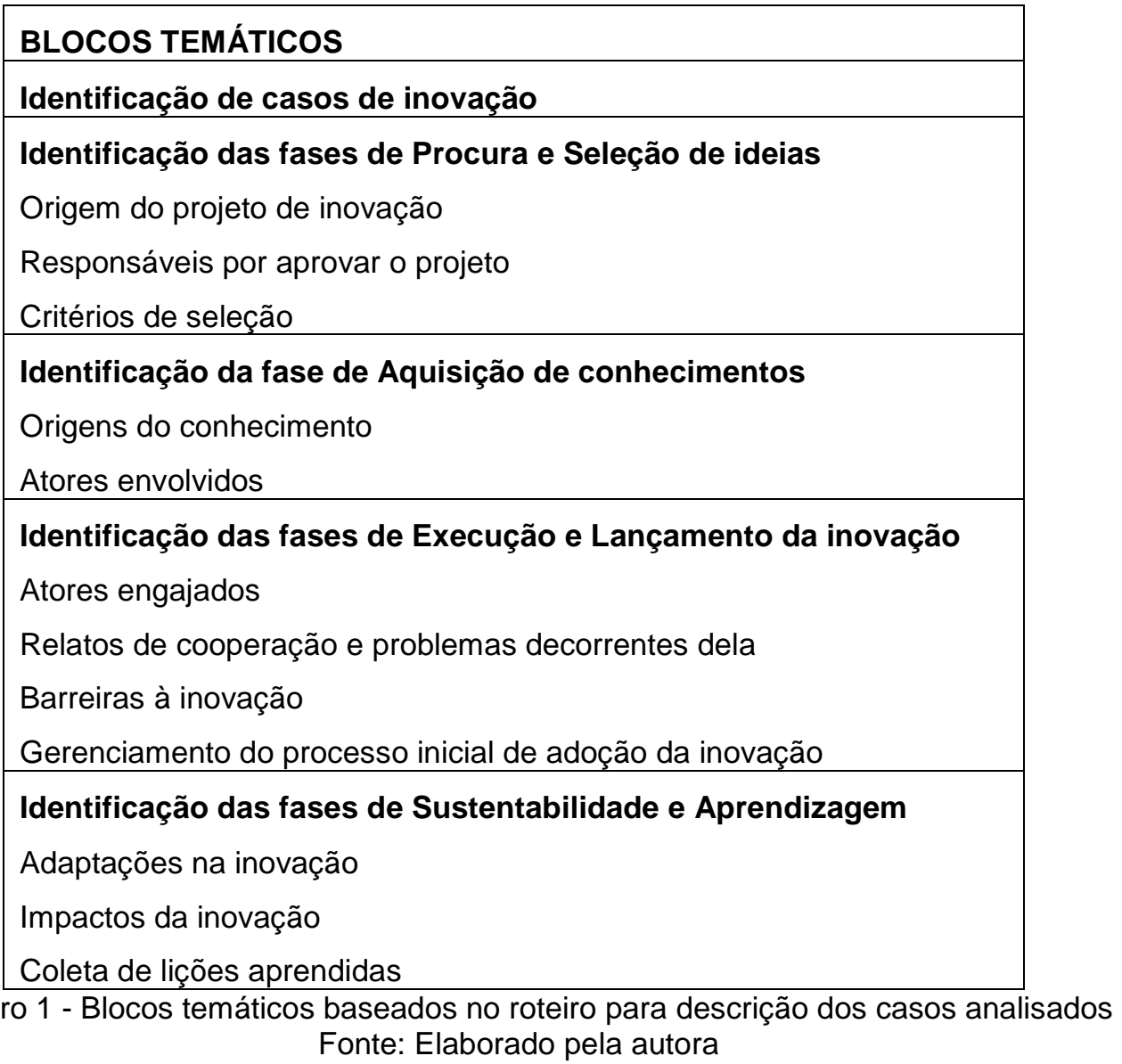

\subsection{Procedimentos de coleta e de análise de dados}

$\mathrm{Na}$ coleta de dados com enfoque qualitativo, o que se procura é "obter informações de indivíduos, comunidades, contextos, variáveis ou situações em profundidade, nas próprias 'palavras', 'definições' ou 'termos' dos indivíduos em seu contexto" (SAMPIERI; COLLADO; LUCIO, 2006, p. 375). O pesquisador deve procurar não interferir na coleta de dados, de forma a obtê-los exatamente como os indivíduos o demonstram.

Neste estudo de casos múltiplos, a principal técnica para a coleta de evidências foi a entrevista, para análise de dados primários. Tendo a organização como nível de análise, foi utilizado o procedimento de entrevista semi-estruturada combinada com uma abordagem narrativa. $\mathrm{O}$ uso da abordagem narrativa permite que a entrevista se concentre em episódios - as inovações - e, assim, que a lógica do processo de inovação seja retomada a partir do relato dos entrevistados. A entrevista foi 
individual e sua aplicação foi feita pessoalmente com pessoas consideradas especialistas no tema abordado, no próprio local de trabalho. Seguindo o que é proposto por Meuser e Nagel (1991 apud FLICK, 2004), durante as entrevistas o pesquisador certificou-se não deixar que ocorressem os seguintes problemas que podem surgir em entrevistas com especialistas:

a) O especialista bloqueia o curso da entrevista, ficando provado que ele não é especialista no tópico;

b) O especialista passa do seu papel de especialista para o de uma personalidade privada, transmitindo número maior de informações sobre ele, como pessoa, do que sobre seu conhecimento de especialista;

c) O especialista passa a palestrar sobre o que sabe, em vez de participar do jogo de perguntas e respostas da entrevista.

Em complemento às entrevistas, foi realizada uma gravação, com o intuito de evitar a perda de informações.

O roteiro de entrevista foi aplicado no período de Julho de 2010. Neste mesmo período também foi realizada a pesquisa documental. Os relatos dos entrevistados foram comparados com os dados recolhidos pela pesquisa documental, permitindo a convergência, ou triangulação dos dados.

Segundo Sampieri, Collado e Lucio (2006), a análise de dados qualitativa possui alguns objetivos centrais, que são: organização dos dados; compreensão do contexto dos dados; descrição das experiências das pessoas pesquisas, na ótica dos entrevistados; interpretação e avaliação de padrões; explicação de fenômenos; e relacionamento dos resultados da análise com a teoria fundamentada.

Neste estudo, a análise de dados se iniciou com uma revisão do material coletado, sendo essa realizada diretamente do meio que a produziu, ou seja, por meio da escuta das gravações e, em adição, utilizando-se da técnica de análise por transcrição escrita.

A estratégia utilizada para a análise dos dados foi a codificação temática, que é aplicada como um procedimento de várias etapas. De acordo com Flick (2004), inicialmente apresenta-se uma breve descrição de cada caso, incluindo-se nela uma breve descrição do entrevistado e os tópicos centrais relacionados ao assunto da 
pesquisa, que, no estudo em questão, são a identificação da utilização ou não das fases genéricas do processo de gestão da inovação proposto por Tidd, Bessant e Pavitt (2008), bem como a identificação das inovações identificadas em cada caso, de acordo com os tipos propostos por Gallouj (2002, 2007). Esta breve descrição será apresentada de acordo com os blocos temáticos do Quadro 1, já apresentado na seção 3.4 .

Logo após a descrição dos casos, desenvolveu-se uma classificação dentro da codificação temática, criando-se categorias comuns às respostas dos sujeitos. Esta estrutura temática desenvolvida para a análise dos casos surgiu a partir da análise do primeiro caso e foi aproveitada para a análise dos demais. A estrutura desenvolvida serve, ainda, para comparar casos, ou seja, para pormenorizar semelhanças e diferenças entre os diversos casos do estudo. Na sequência são apresentadas as categorias utilizadas na análise realizada:

1) Confrontação das inovações relatadas em cada caso com os tipos de inovação;

2) Análise das fases de procura e seleção de ideias;

3) Análise da fase de aquisição de conhecimentos;

4) Análise das fases de execução e lançamento da inovação;

5) Análise das fases de sustentabilidade e aprendizado adquirido com a inovação. 


\section{RESULTADOS E DISCUSSÃO}

Esta etapa do estudo se inicia com uma seção de apresentação dos dados, na qual uma breve descrição dos relatos dos entrevistados nos seis casos é divulgada. As informações de cada caso são apresentadas sequencialmente considerando a ordem dos blocos temáticos definidos na seção 3.4.

Posteriormente, na seção 4.2, são apresentadas as análises dos seis casos selecionados para o estudo. As análises são realizadas considerando a ordem dos blocos temáticos e as categorias de análise compreendidas em cada bloco, já explicitadas na seção 3.5. Aqui serão também comparados os casos e confrontados os resultados das análises com a literatura.

\subsection{Apresentação dos Casos}

\subsubsection{Caso A}

A empresa relatada no Caso A surgiu em Brasília e começou a operar em 1987 como uma empresa de consultoria, tendo, a partir de 1990, incorporado trabalhos de prestação de serviços na área de tecnologia da informação. $O$ entrevistado foi o próprio diretor-presidente, fundador da empresa e seu maior idealizador.

Durante seu histórico, a empresa foi sofrendo diversas mudanças de foco de trabalho, sem abandonar o que fazia antes. Foi a empresa pioneira na área de Gerenciamento Eletrônico de Documentos (GED), a empresa pioneira na área de ensino à distância e a empresa pioneira na área de fábrica de software. Cada projeto de novo produto ou serviço que prospera na empresa passa a constituir uma área de negócio e depois pode gerar uma empresa. Sendo assim, a empresa do Caso $\mathrm{A}$ atualmente faz parte de um grupo formado por empresas de consultoria, $\mathrm{TI}$, ensino à 
distância, gestão de conteúdos, gestão educacional, além de uma fundação para projetos sociais.

O faturamento do grupo como um todo, no ano de 2009, foi de aproximadamente 120 milhões de dólares. O organograma da empresa pode ser observado no Apêndice B.

Os principais serviços oferecidos pela empresa são outsourcing, fábrica de software, projetos de segurança da informação, gestão de acervos, virtualização de conhecimento e soluções de portais para ambientes de intranet e internet. A carteira de clientes da empresa é composta, em sua maioria, pelo governo, em níveis federal, estadual e municipal, compondo cerca de $85 \%$ da clientela total.

\subsubsection{Identificação de casos de inovação}

No Caso A, foram citadas duas vertentes de inovação. A primeira vertente, vista pelo entrevistado como um pré-requisito para a sobrevivência da empresa, consiste em inovações nos processos de trabalho. Para garantir estas melhorias em processos, a empresa busca implantar procedimentos e normas internacionais, como as certificações ISO 27000, ISO 9000, ISO 14000, ISO 17000 e Capability Maturity Model Integration (CMMI). Nas palavras do entrevistado, "isso provoca uma revolução nos métodos e procedimentos de trabalho. Então tudo o que a gente faz de trabalho passa a ser tutelado por isso aqui, então isto aqui é um tipo de inovação, é um tipo de preocupação com o caminho da empresa". A empresa foi a primeira do Brasil a ser certificada pela ISO 27000, de Segurança. O entrevistado citou ainda que a ISO 17000, que é a norma voltada para a responsabilidade social, os levou a criar uma Fundação para exercer esta função.

A outra vertente de inovação citada é o próprio mercado. Visto que o mercado de TI muda com rapidez, é necessário atenção para as tendências, para a evolução da tecnologia e para as necessidades do ambiente. O entrevistado citou como exemplo a própria digitalização, que há 15 anos era um grande negócio e que hoje, com a evolução da tecnologia, não tem mais validade como função. Em sua visão, a evolução da tecnologia tomará conta de trabalhos braçais, como digitalização e 
programação, e as empresas deixarão de contratar um analista de sistemas convencional para ter um analista de inteligência.

Uma das mudanças ocorridas nos últimos anos na empresa foi com relação ao próprio entendimento da tecnologia. Antes, vendia-se ao cliente a tecnologia pela tecnologia, ou seja, não havia uma análise se aquele produto ou serviço vendido iria realmente solucionar o problema no cliente. Hoje a empresa do Caso A visa ser uma empresa que apresenta soluções de aplicação do conhecimento para resolver problemas.

O principal caso de inovação observado, desenvolvido recentemente pela empresa e patenteado na França, chama-se Gestão de Vetores Epidemiológicos (GVE). O GVE foi concebido como uma nova forma de erradicar a dengue. Trata-se de um produto com cinco plataformas de software, sendo uma o ambiente do cidadão, de forma que o cidadão deixa de ser vítima e passa a ser um agente ativo no combate aos vetores que transmitem doenças. Outra plataforma é um ambiente móvel, conectado a um microcomputador com tecnologia de ponta, que gerencia todo o processo de erradicação da dengue nas casas da população em tempo real. O agente de saúde, que antes levava entre 45 e 60 dias para ter um diagnóstico de casos de mosquitos transmissores de dengue nas casas da população, por meio do GVE passará a gastar apenas 30 minutos. Os resultados dessa inovação são tratamento do local infectado na mesma hora, além de impedir a proliferação do mosquito e a ocorrência de outras epidemias de dengue. Este produto é considerado uma evolução na saúde pública e será lançado no mercado em 2010.

\subsubsection{Identificação das fases de Procura e Seleção de ideias}

No Caso A, geralmente as inovações surgem dentro da própria empresa. Um exemplo claro são as diversas empresas que hoje compõem o Grupo e que foram concebidas inicialmente como projetos de pesquisa. Uma das empresas do Grupo, de ensino à distância, começou como um projeto de pesquisa e hoje é líder de mercado na América do Sul. 
O entrevistado diz, ainda, que as ideias não surgem ao acaso, surgem de uma observação da realidade, ou seja, da observação dos problemas cotidianos e reflexão sobre como saná-los. O caso do GVE corrobora esta ideia, já que foi uma inovação surgida por meio de observação de um problema, o problema das epidemias de dengue na população.

O entrevistado citou, ainda, como prática da empresa uma reunião denominada Reunião do Nada, em que os participantes não podiam vir com ideias preconcebidas e deveriam ser discutidas oportunidades gerais de melhoria.

"Você tem que ser inconformado por natureza. [...] Porque sempre existe algo melhor a ser feito. Então esse é o princípio que motiva a pesquisa, a inventividade. $\mathrm{E}$ a fonte principal é esse exercício, que não acontece aqui nas quatro paredes não, a

ideia ela pode acontecer em qualquer lugar e de uma maneira mais informal possível. Agora você tem que ter uma ambiência pronta para receber isso e avaliar e dar destinação à ideia."

O entrevistado citou também que não possuem um sistema rígido de seleção de ideias.

"Nós não temos um processo, porque você não pode botar a inovação dentro de uma camisa de força, você não pode ter um sistema rígido de avaliação [...]. Você tem que ter um processo de construção de hipóteses sobre aquilo. Esse processo ele tem que ser o mais natural possível e o mais informal possível."

Apesar do interesse de manter a informalidade neste processo inicial, um fato que mostra a preocupação da empresa com o tratamento da inovação, desde a concepção, é a existência da Coordenação de Inovação Tecnológica, a área mais recente do organograma da empresa, que visa receber e expandir projetos de inovação propostos. 


\subsubsection{Identificação da fase de Aquisição de Conhecimentos}

$\mathrm{Na}$ fase de aquisição de conhecimentos, o entrevistado cita que a empresa procura primeiro internamente as competências necessárias e, quando percebem que elas não são suficientes, buscam oportunidades de adquirir no meio externo.

Como exemplo, o entrevistado lembra-se dos primeiros projetos GED da empresa. Há 15 anos, softwares de gerenciamento de documentos eram mantidos fora do Brasil a sete chaves. Com o surgimento da demanda por estes softwares vinda de um cliente, a empresa procurou este conhecimento no mercado e não obteve êxito. Devido a este fato, montaram um grande grupo de pesquisa, começaram a estudar e desenvolveram um produto brasileiro para esta demanda.

\subsubsection{Identificação das fases de Execução e Lançamento da inovação}

Com relação aos atores engajados nas inovações, utilizando-se do caso de inovação do GVE, nota-se grande contribuição entre diferentes pessoas, já que o mesmo foi desenvolvido por uma equipe multidisciplinar, com especialistas de áreas como biologia, entomologia, saúde pública, além dos profissionais de $\mathrm{TI}$ da empresa. Outra cooperação no caso do GVE é que a empresa fez um acordo comercial com uma empresa chinesa para a produção dos equipamentos, que são depois mandados para o Brasil.

Outro exemplo de engajamento entre diferentes atores pode ser percebido no projeto de pesquisa para a criação de um sistema de gestão acadêmica para a Universidade Católica de Brasília, desenvolvido em conjunto com a própria instituição.

O entrevistado considera a cooperação muito importante para as inovações. A empresa cultiva o hábito de fazer acordos de cooperação técnica com universidades e centros de pesquisa. Possui acordos não só com universidades de Brasília, mas também com a Universidade de Campinas e a Universidade de São Paulo; e também com pessoas consideradas referência em determinadas áreas, que são convidadas a participar dos projetos. 
Com relação ao desenvolvimento da inovação, o entrevistado mencionou que todo trabalho de pesquisa da empresa nunca dependeu de financiamentos do governo. A única vez que apresentaram um projeto para a FINEP, o projeto GVE, decepcionaram-se, pois não obtiveram aprovação por concorrerem com projetos de jogos eletrônicos pela internet.

Quando se trata das barreiras ao desenvolvimento da inovação, uma grande dificuldade considerada é o recurso financeiro, ou a falta dele. Já na fase de implantação da inovação, a principal barreira advém da resistência ao novo.

"A resistência advém de duas coisas, eu acho: da falta de conhecimento daquilo, e, à medida que a pessoa conhece, ela acha ótimo, porque vai facilitar a vida dela, essa é fácil de reverter. $E$ a resistência que advém do medo de perder a sua posição, o seu status, a aplicação do conhecimento que ela até então tem. Tem gente que se julga dono das informações sobre determinada coisa, então ele não deixa mexer naquilo de jeito nenhum, porque senão ele perde o controle que tem sobre determinada situação. Esta, para reverter, é preciso uma posição mais contundente de quem dirige para mudar."

Para falar do gerenciamento do processo inicial de adoção da inovação, pode-se citar o caso do GVE. Desde a construção da inovação até a fase de teste, a empresa cria um grupo com conhecimentos complementares. No projeto GVE, o grupo foi formado por um gerente geral, um gerente de tecnologia, um gerente de conhecimento do problema e as equipes técnicas. No momento de vender o produto, é formado um novo grupo com know-how comercial. O gerente do projeto e sua equipe definem a melhor estratégia para o produto; no caso do GVE, a decisão foi a criação de uma empresa específica para comercialização.

\subsubsection{Identificação das fases de Sustentabilidade e Aprendizagem}

Em se tratando de adaptações à inovação para garantir sua sustentabilidade a longo prazo, a empresa vê esta etapa como essencial no mercado de tecnologia. $O$ 
entrevistado citou que, quando a equipe de produção está trabalhando em uma primeira versão de um projeto, a equipe de desenvolvimento já está desenvolvendo o que será a inovação na segunda versão. Diz, ainda, que não há uma periodicidade neste processo, ele ocorre eternamente.

Com relação ao aprendizado adquirido com uma inovação para evitar erros posteriores, citando o caso do GVE, a empresa possui um relatório de problemas que aconteceram ao longo da execução do projeto de pesquisa.

\subsubsection{Caso B}

O entrevistado do Caso B ocupa o cargo de Coordenador de Pré-Venda, atuando diretamente com a diretoria comercial. Sua equipe possui contato próximo com os vendedores, apesar de as funções executadas por ela serem mais técnicas. O entrevistado trabalha há 5 anos no grupo, sendo 2 deles na empresa selecionada. Possui 12 anos de experiência na área de TI, 8 deles em cargos de gerência.

A empresa atua há 7 anos no mercado e faz parte de um grupo que tem mais de 15 anos. O grupo é composto de 4 empresas; as outras 3 atuam nas áreas de segurança, notas fiscais eletrônicas, datacenter e cloud computer.

O faturamento do grupo no último ano fiscal foi de cerca de $R \$ 350$ milhões. $A$ empresa vem sofrendo aumentos em seu faturamento de mais de $30 \%$, sendo uma das únicas empresas de $\mathrm{TI}$ do Brasil a alcançar este marco em dois anos consecutivos. Possuem em torno de 1500 funcionários. Possuem 3 filiais - Brasília, Rio de Janeiro e Belo Horizonte - e a matriz em São Paulo. A empresa está se preparando para abrir o capital, num processo de colocação de ações na Bolsa de Valores.

Os principais serviços ofertados pela empresa são: datacenter; outsourcing; BPO; serviços de alta disponibilidade; mobilidade; e desenvolvimento de sistemas e serviços (fábrica de software). Os principais contratos da empresa estão na área de outsourcing e ela é considerada a maior empresa do país de BPO em projetos voltados para atendimento ao cidadão. 
Quanto aos principais clientes, o entrevistado explicou que em Brasília a empresa é mais focada no mercado público, tendo clientes como Banco do Brasil, Caixa Econômica, Banco Central, SERPRO e Dataprev.

\subsubsection{Identificação de casos de inovação}

O entrevistado cita a vertente dos serviços como um grande caso de mudança na empresa. Ele explica que, antes, todos os contratos, principalmente com o governo, eram contratos de alocação de mão-de-obra, em que a empresa alocava seus funcionários e o gerenciamento deles era feito pelo cliente. Com isso, o cliente arcava com todos os custos do funcionário terceirizado, sendo que deveria pagar somente pelo serviço prestado. Esta realidade está mudando no governo e é uma iniciativa que já tinha acontecido antes no mercado privado.

"Ninguém mais quer pagar pelo cafezinho, pelo tempo que o terceirizado vai ao médico, pela saída dele para resolver um problema pessoal... Eu quero um serviço.

Se você vai estar fazendo isso com uma, duas ou três pessoas, não é do meu interesse. Eu quero apenas que os meus servidores sejam administrados durante um ano sem parar".

Houve, então, uma mudança drástica, em que o funcionário não precisa mais estar alocado dentro do cliente, pode trabalhar dentro da própria empresa.

Outra tendência de mercado atual, que é uma grande inovação na empresa, é o cloud computer. Segundo o entrevistado, as pessoas estão cada vez mais se desfazendo de seus servidores e querendo desktops mais simples, de forma que, para armazenarem seus arquivos, utilizem servidores virtuais, também chamados de servidores "na nuvem".

"Você só vai precisar de um link na internet e de uma máquina simples para acessar seus arquivos na nuvem. É o que tem hoje no Gmail, no Hotmail, gratuitos, 
só que de forma corporativa, ou seja, de uma forma mais segura, mais organizada, em que eu tenha outros tipos de ferramentas de colaboração embutidas, não é só o e-mail".

"A Apple é outra empresa que está seguindo essa linha também. Todos os serviços da Apple você baixa simplesmente hoje. Quem tem o iPhone, iPod, baixam

um software chamado iTunes, onde você pega diversos serviços que estão na nuvem. Você compra livro na nuvem, música na nuvem, e não precisa armazenar só no seu dispositivo, você pode inclusive se quiser, deixar na nuvem".

Já na área de Mobilidade, em que se criam aplicações para dispositivos móveis, uma inovação da empresa é um projeto pioneiro no país realizado para a Caixa Econômica. Neste projeto está sendo desenvolvido um terminal, como um notebook, atrelado a uma pequena máquina móvel, que visa reduzir filas de pagamentos de contas, favorecendo clientes que têm poucas operações bancárias a realizar. Esta máquina possui também uma impressora embutida, que emite instantaneamente 0 extrato bancário. De acordo com o entrevistado, não há nada semelhante sendo desenvolvido no país.

\subsubsection{Identificação das fases de Procura e Seleção de ideias}

Para entrar nas fases do processo de inovação, o entrevistado focalizou na inovação do cloud computer. Segundo ele, no mercado de TI a inovação geralmente surge nos grandes fabricantes mundiais - IBM, Microsoft, Oracle, Apple -, porque são empresas que têm a possibilidade de investir grande parte de seu faturamento em pesquisas. Então, o mercado nacional, principalmente por não haver nele grandes fabricantes, acaba tendo como principais referências às inovações estas multinacionais.

"A primeira vez que alguém ouviu falar de cloud computer saiu de uma dessas empresas. Então, por exemplo, uma das grandes empresas inovadoras que começou a forçar o mercado de cloud computer foi o Google. O Google começou a 
lançar os seus produtos e tudo baseado na nuvem. Se você quiser, você tem tudo lá no Google: diretórios para guardar seus arquivos, e-mail, agenda, calendários, ferramenta de pesquisa, de idiomas. O Google começou essa mudança no mercado. $E$ todos começaram a enxergar que realmente é necessário. Então realmente essas mudanças começam ainda no mercado fora do país, e aí obviamente o Brasil vai seguindo a linha mundial".

Com relação à seleção de inovações dentro da empresa, o entrevistado mencionou que as decisões de investimentos vêm do Conselho Deliberativo, formado pela sócia majoritária e demais acionistas, sendo que um dos integrantes do conselho é um ex-CEO da Microsoft Brasil. E de tempos em tempos, o Conselho seleciona algumas pessoas do corpo técnico para participar de reuniões específicas, apoiando as decisões.

Questionado sobre os critérios que determinam entrar ou não em determinada tendência, o entrevistado citou que se algo está despontando no mercado internacional, então isso já é um dos critérios de decisão, pois o mercado brasileiro se assemelha muito ao mercado dos Estados Unidos e Europa em termos de aquisição de tecnologia. Outro fator que ajuda na decisão é o mercado-alvo da empresa:

"Por exemplo, o governo vai demorar muito a entrar nessa situação de cloud computer. Se eu sou uma empresa que meu foco é governo, não vale a pena eu de repente investir em cloud computer. Não é o caso, já de três anos para cá que a nossa orientação é que nós temos que, sem 'diminuir o tamanho da pizza', aumentar o meu faturamento em mercado privado. Mantenho o governo com o que eu tenho hoje, e até amplio, mas eu tenho que aumentar cada vez mais o mercado privado".

Em síntese, a empresa tem uma orientação para a tecnologia que vem do fabricante, e, com isso, analisam o mercado e avaliam se é o momento de adotar determinada inovação ou não. 
"Então, por exemplo, mobilidade: quando surgiu há uns quatro anos e eram coisas muito simples e pequenas, a empresa não se interessou. Quando o mercado começou a se mostrar com esse grande projeto da Caixa, que começou a ser estudado há seis anos, outros clientes e outros bancos começaram a olhar para o mercado de mobilidade de uma forma diferente, e a gente começou a ver que passaria a ser uma oportunidade até em termos de receita maior, aí a empresa começou a pensar que era uma área para começar a investir".

\subsubsection{Identificação da fase de Aquisição de conhecimentos}

Com relação aos conhecimentos que contribuíram para as inovações, o entrevistado mostra que uma qualidade da empresa é investir em seu corpo técnico e mantê-lo atualizado. Possuem um Programa de Certificação ${ }^{3}$ em que a empresa incentiva os funcionários a participar, reembolsando o valor da prova, caso 0 profissional seja aprovado. Hoje a empresa possui mais de 1300 certificações técnicas.

Em situações específicas, são trazidas pessoas de fora da empresa para transmitir um novo conhecimento. Como exemplo, em contrato firmado com uma empresa do setor privado, encontraram nela uma tecnologia conhecida por apenas quinze profissionais no país inteiro aproximadamente. Nesta situação, contrataram uma empresa que conhecia desta tecnologia e investiram neste conhecimento para os profissionais do corpo interno da empresa, inclusive com treinamentos no exterior. Com isso, conseguiram assumir o contrato com este cliente.

Não é muito comum na empresa participação de instituições de ensino na aquisição de conhecimentos, porém ocorre esporadicamente. Há dois anos, a empresa fez um acordo com a Fundação Getúlio Vargas e foi criada uma turma de pós-graduação fechada para os funcionários, com conteúdo totalmente voltado para o mercado de TI e tendências de negócios.

\footnotetext{
${ }^{3}$ No mercado de $\mathrm{TI}$, os principais fabricantes, quando lançam uma tecnologia, cerca de dois meses depois lançam as certificações nesta tecnologia. O profissional faz uma prova, na qual recebe, caso seja aprovado, uma certificação de que é um consultor especialista naquela tecnologia. Com isso, é possível medir a qualidade do mercado.
} 
4.1.2.4 Identificação das fases de Execução de Lançamento da inovação

Quanto aos atores engajados na inovação, em um primeiro momento começa-se com a diretoria e o conselho de sócios, que vão selecionando pessoas específicas. Dentro da atual estrutura, apesar de ser uma empresa de médio para grande porte, a diretoria ainda consegue elencar pessoas chave para auxiliar na análise de projetos, de acordo com a tecnologia envolvida na mudança. Os fabricantes também são considerados atores engajados, pois seu apoio é necessário em treinamentos nas novas tecnologias lançadas no mercado.

A cooperação com outras empresas é bastante intensa nesta organização. Dentro da célula de mobilidade, possuem uma parceria com uma empresa especializada em soluções de dispositivos móveis.

"Hoje ele é nosso parceiro, ele só tem contrato com a gente, ele só presta serviço pra gente, ele está quase virando a vertical nossa de Mobilidade, e está sendo já estudada a compra da empresa, para virar mais uma empresa do grupo. Então isso acontece muito, colaboração entre empresas, e dependendo do tamanho e do porte, uma depois acaba adquirindo a outra".

Problemas decorrentes da cooperação também ocorrem. Até o último ano fiscal havia no grupo uma empresa, que agora não faz mais parte da sociedade, especializada em documentação de sistemas legados, comprada em decorrência de uma parceria em que se viam grandes oportunidades futuras. Mas as expectativas de demanda para aquela aplicação não superaram as expectativas iniciais. Segundo o entrevistado, um dos fatores principais da falta de demanda era que, "principalmente dentro do governo, os órgãos tinham receio e medo de passar seu código fonte, mesmo com um contrato de sigilo".

"Pensa em um grande banco público, que tem uma aplicação que tem todas as contas correntes, todas as informações dos correntistas... e ele vai estar lidando com uma empresa que, por mais que tenha contrato de sigilo, dentro dela está 
lidando com profissionais, quem garante que um profissional desse não vai pegar o código fonte, descobrir brechas e depois fazer um ataque para tentar pegar informação do Banco? Então os órgãos ficavam receosos".

Com relação às barreiras à inovação, o entrevistado cita que elas podem surgir inclusive do próprio fornecedor, quando este muda algo em sua tecnologia. Em um caso recente, a empresa ficou impedida de participar de várias licitações, porque a tecnologia utilizada por seu fornecedor era bloqueada nos editais.

"Ele fez uma mudança na estrutura do equipamento que hoje nos prejudica em licitações de governo. Porque ele foi com uma tendência nova de mercado, há dois anos, que agora é que está começando a ser difundida. E com isso, os outros fabricantes, quando estavam auxiliando os órgãos a escrever seus editais, bloquearam essa tecnologia nova".

Outra barreira listada pelo entrevistado, que em alguns momentos os impede de inovar, é conseguir a aprovação de investimentos com o Conselho.

"Porque, quer queira quer não, isso não é uma estrutura de multinacional, isso é uma estrutura de uma empresa de médio para grande porte que ainda têm donos, o Conselho é formado por donos. Então qualquer investimento sai do bolso dos donos, é dinheiro que eles poderiam até estar investindo em outras coisas".

\subsubsection{Identificação das fases de Sustentabilidade e Aprendizagem}

No exemplo da inovação cloud computer, um fato que mostra a preocupação com a sustentabilidade da inovação a longo prazo é o fato de o grupo ter criado uma empresa exclusiva para este serviço, após verificada a tendência de crescimento do interesse do mercado nesta solução. 
Nas inovações em Mobilidade, uma melhoria já implementada e que não acontecia há cerca de três anos, quando começaram a atuar nesta área, é que agora não estão mais trabalhando com um só dispositivo de Mobilidade. Segundo o entrevistado, "em um primeiro momento a gente estava muito focado neste dispositivo, porque era um grande projeto que nós queríamos. Hoje nós estamos trabalhando com pelo menos cinco dispositivos diferentes".

Com relação aos impactos dentro da empresa decorrentes das inovações em Mobilidade, o entrevistado mencionou que esta tecnologia, principalmente estes dispositivos móveis mais focados na área financeira, causam forte impacto em termos de lucratividade, tanto porque os clientes são de grande porte, quanto pelo fato de hoje só existirem duas empresas no mercado nacional especializadas neste tipo de venda.

No processo de coleta de lições aprendidas com as inovações, mensalmente existem reuniões internas que analisam números, investimentos e resultados gerados por uma inovação. E trimestralmente o Conselho se reúne com os CEOs de cada empresa do grupo para que estes apresentem as informações dos projetos e sejam feitas avaliações.

\subsubsection{Caso C}

O entrevistado do Caso C é supervisor comercial da empresa. Em sua função, atua diretamente com os sócios-diretores. Trabalhou na empresa por cinco anos como consultor e está há um ano em seu atual cargo. A empresa possui 25 anos de mercado, mais de mil funcionários e seu último faturamento anual foi cerca de $R \$ 30$ milhões.

O organograma desta empresa encontra-se no Apêndice B. A Presidência e as Diretorias ficam localizadas em São Paulo. Dentro de cada uma das diretorias abaixo da Diretoria Geral estão os supervisores e consultores, ambos localizados em Brasília e outras regiões. Em Brasília funciona toda a parte de suporte e a parte comercial; o desenvolvimento de serviços e sistemas (fábrica de software) é feito em São Paulo, São José do Rio Preto e Campo Grande. 
O principal serviço ofertado pela empresa é o desenvolvimento de softwares que automatizam funções administrativas e contábeis. Os principais clientes são empresas que atuam dentro do lucro real ou do lucro presumido, pois seus softwares são desenvolvidos com uma estrutura própria para estes tipos de tributação.

\subsubsection{Identificação de casos de inovação}

Uma das inovações citadas pelo entrevistado e criada na própria empresa chama-se Office2 CRM. É um programa virtual que permite que uma empresa terceirizada, após gerar todos os documentos de seu cliente, os publique em seu site, no qual o cliente possui um login e uma senha e pode fazer o download de seus documentos e imprimi-los em sua empresa. Feito isso, automaticamente é gerado um protocolo identificando o computador que recebeu aqueles documentos, para fins de segurança. Outra vantagem deste sistema é que um cliente que usa um Enterprise Resource Planning (ERP), no qual lança toda a sua movimentação financeira, ao final do processo gera um arquivo e pode enviar seu movimento mensal pelo Office2 CRM virtualmente para sua contabilidade terceirizada, e nela é feita a integração contábil.

"O normal hoje é que o contador, por exemplo, solicite um motoboy que vá fazer a entrega física destes documentos à empresa, então o empresário assina 0 protocolo de recebimento e finaliza-se o processo. Então esta é uma solução inovadora".

Outra inovação observada na empresa foi uma mudança na forma de atendimento aos clientes. Foi identificado que os funcionários do service desk trabalhavam pelo cliente, acabando por vetar o aprendizado deste em determinada ferramenta. 
"Por exemplo, o cliente tem um problema no sistema e liga para o suporte perguntando como resolvê-lo. O analista entrava no sistema, resolvia o problema e finalizava a ligação. Esta não é a forma de atendimento correta. $O$ atendimento correto seria: quando o cliente liga com um problema, o suporte dá para ele as instruções de resolução do problema e acompanha pelo telefone o andamento do cliente no passo a passo. O cliente não aprenderá da primeira vez, mas é o primeiro passo para o aprendizado".

Outra inovação verificada é no mercado-alvo. Há dois anos a empresa não trabalhava com soluções para o ramo industrial. A ideia de migrar para este ramo foi uma necessidade que surgiu; começaram a chegar à empresa várias demandas para este tipo de serviço e com isso perceberam que valeria a pena investir no setor.

4.1.3.2 Identificação das fases de Procura e Seleção de ideias

No que tange à procura de inovações, o entrevistado diz que há ideias inovadoras que surgem informalmente na empresa, até mesmo em momentos de descontração entre os funcionários. Apesar disso, menciona que a maioria das inovações surge das necessidades diárias:

"Mas a maioria surge na necessidade diária. As ideias começam com um porte muito pequeno: a necessidade aparece, se torna um problema, este problema é resolvido e começamos a identificar que aquele problema pode gerar dinheiro. E aí é onde você começa a desenvolver uma nova solução".

Questionado sobre quem dentro da empresa seleciona as ideias que se tornarão inovações, o entrevistado diz que não é a diretoria que tem este papel, ela simplesmente dá o aval. Na verdade, quem analisa e diz se uma inovação é viável ou não são os próprios programadores e analistas de software. 
Apesar disso, no caso do Office2 CRM, uma das grandes idealizadoras foi a diretora da empresa, que percebeu que quanto maior o porte de seus clientes, maior era a sua movimentação de informações e maior o tempo despendido no lançamento destas informações em sistemas. Percebeu, então, que a transmissão virtual de dados era uma forma de resolver o problema destes clientes.

\subsubsection{Identificação da fase de Aquisição de conhecimentos}

Com relação às habilidades necessárias para desenvolver uma solução, o entrevistado citou que o processo costuma ter início com a busca de informações sobre bancos de dados e linguagens de programação. E estas informações são conseguidas por meio da plataforma ITIL (Information Technology Infrastructure Library), uma metodologia de trabalho em que se acumulam todas as informações possíveis sobre assuntos importantes no desenvolvimento de projetos, e que são gravadas dentro de uma base, fazendo com que a informação seja disseminada a todos por meio de um único software. Funciona como uma biblioteca, e é uma ferramenta utilizada por diversas empresas de TI.

Outra forma de adquirir conhecimentos é por meio de uma empresa dos mesmos sócios, que é um centro de treinamentos especializado em treinar os funcionários da empresa nos sistemas por ela desenvolvidos.

\subsubsection{Identificação das fases de Execução e Lançamento da inovação}

Com relação ao processo de desenvolvimento das inovações, no caso do Office2 CRM e de outros softwares, o processo dura em torno de 14 meses, de acordo com o entrevistado. Depois disso, há ainda a fase de homologação, na qual se seleciona um cliente e negocia-se com ele a sua participação em um projetopiloto no novo software.

No tocante às barreiras à inovação, o entrevistado citou que o sistema Office2 CRM foi criado há seis anos, porém houve grande resistência a sua utilização na 
época, pois os clientes consideravam as inovações que envolviam trocas de informação em meio virtual pouco seguras.

"Hoje em dia, de uns três anos para cá, a digitação se tornou um trabalho braçal visto como retrabalho, mas muita gente não entendia isso antes. Achavam normal ficar digitando uma pilha de documentos em um sistema contábil que outra empresa já tinha digitalizado em seu sistema financeiro. Hoje em dia as empresas prezam pela transferência de dados: pegam os arquivos, importam para o sistema e fazem somente uma verificação".

"Quando se tira alguém de sua zona de conforto ela se assusta. Mas é para isso que existem as palestras de conscientização para os clientes. A gente convidava uma carta de clientes para palestras sobre gestão de softwares e, quando isso aconteceu, com o tempo este tipo de serviço se tornou uma realidade".

Outra barreira, verificada na implantação da inovação que ocorreu no processo de atendimento de clientes, tem também a ver com gestão da mudança. Houve certa dificuldade em implantar as melhorias propostas, já que os funcionários estavam acostumados a trabalhar de uma forma diferente.

"Quando você tira uma pessoa da zona de conforto dela para aplicar uma inovação há muita resistência. Muitas vezes há uma ideia ótima para executar que só é implementada depois de muito tempo, pois ela depende das pessoas. A gestão da mudança, nesses casos, depende muito do gestor que está à frente, se ele vai ser capaz de mudar as pessoas e a forma como elas trabalham os processos".

\subsubsection{Identificação das fases de Sustentabilidade e Aprendizagem}

A aprendizagem gerada por uma inovação e utilizada em projetos futuros pode ser observada na empresa pela utilização do ITIL: 
"Quando o problema de um cliente é resolvido, o consultor então coloca as lições aprendidas dentro do ITIL, o que era o problema e como se resolveu. No ITIL colocam informações sobre banco de dados, como cada um funciona, para que serve, o que significam as siglas... Facilita no desenvolvimento de futuros sistemas que precisam de informações sobre bancos de dados e linguagens".

\subsubsection{Caso D}

O cargo do entrevistado desta empresa é de Project Management Officer (PMO), que faz parte da assessoria Project Management Office (PMO) e atua diretamente com a diretoria de Brasília. O organograma da filial Brasília encontra-se no Apêndice D.

É uma empresa de grande porte, possui capital aberto e seu faturamento foi de $\mathrm{R} \$ 1,1$ bilhão em 2009. Faz parte de um grupo de várias empresas que atuam em diversas frentes, como: prestação de serviços de softwares de gestão corporativa para empresas de todos os portes, consultoria e segmento de televisão digital.

Os principais serviços ofertados pela empresa são consultoria empresarial, inclusive de fusões e aquisições; desenvolvimento de sistemas; help-desk; e ensino à distância. A empresa atende a clientes de todos os públicos, mas existem alguns segmentos priorizados, tais como agroindústria, saúde, manufatura, educação, distribuição e logística.

\subsubsection{Identificação de casos de inovação}

Um tipo de inovação citado pelo entrevistado são as melhorias feitas nos softwares. Estas são geralmente demandadas pelos analistas de sistemas, que estão em contato diário com os softwares e são os responsáveis por implantá-los. No caso de ser uma demanda de um cliente, é considerada uma customização para atender a uma realidade específica. Estas melhorias ocorrem constantemente. 
Outras duas inovações recentes ocorreram em um processo. A metodologia de implantação de sistemas da empresa é formalizada na forma de um fluxograma, desde a fase de início até a fase de implantação e encerramento do projeto. Este processo está em constante mudança. A primeira inovação recente foi a inserção da metodologia Scrum ${ }^{4}$, que é uma metodologia de gerenciamento de projetos específica para TI. Antes, a metodologia utilizada pela empresa era totalmente baseada no Project Management Body of Knowledge (PMBOK). A segunda inovação neste processo é a utilização de Net Promoter Score (NPS) ${ }^{5}$, um indicador utilizado para avaliar a satisfação dos clientes.

\subsubsection{Identificação das fases de Procura e Seleção de ideias}

Como já colocado, as melhorias nos softwares podem surgir de demandas dos clientes ou dos próprios analistas de sistemas. A seleção de melhorias nos sistemas ocorre da seguinte forma: os analistas trazem a proposta de mudança para o gestor de portfólio de Brasília e este analisa se realmente é uma mudança interessante e viável. Caso seja, o analista faz uma requisição diretamente para o pessoal de desenvolvimento da matriz, que fica em São Paulo. A proposta, então, passa por um processo de aprovação com base em critérios de rentabilidade e de possibilidade de utilização da inovação em outros clientes. Outro critério que determina a necessidade de alterações nos softwares são mudanças na legislação, que muitas vezes obrigam a ocorrência de atualizações em ferramentas dos sistemas.

"Neste momento estão querendo derrubar o Regime Especial de Apuração, que modifica as formas de apuração de impostos. Logo, nossos sistemas contábeis e fiscais devem estar adequados a isso. Logo, as pessoas da empresa precisam estar atentas a estas informações do meio externo".

\footnotetext{
${ }^{4}$ A palavra não é um acrônimo.

${ }^{5}$ O NPS baseia-se em uma perspectiva de que os clientes de qualquer empresa podem ser divididos em três categorias - promotores, neutros ou detratores - por meio da resposta a uma pergunta simples: Você recomendaria esta empresa a um amigo?
} 
Como observado, as inovações não costumam vir de atores externos à organização, com exceção dos clientes. Porém, o PMO está sempre à procura de novas tendências e metodologias que são encontradas no meio externo.

\subsubsection{Identificação da fase de Aquisição de conhecimentos}

Nesta empresa, há diversos conhecimentos que são adquiridos no meio externo, como, por exemplo, conhecimentos sobre o sistema Project e sobre a metodologia Scrum, que foram adquiridos por meio de treinamentos ministrados por pessoas de fora da organização.

\subsubsection{Identificação das fases de Execução e Lançamento da inovação}

Com relação à cooperação, como a empresa faz parte de um grupo bastante diversificado, as melhores práticas utilizadas por uma empresa são constantemente repassadas às demais. Como exemplo, o entrevistado citou que uma das empresas do grupo, quando foi adquirida, tinha uma excelente metodologia de gerenciamento de projetos, que rapidamente foi incorporada às demais empresas.

A colaboração durante o desenvolvimento das inovações também é observada no contato com os clientes. Segundo o entrevistado, cerca de $80 \%$ de seus clientes possuem internamente um funcionário especializado na área de $\mathrm{Tl}$, que deve ser uma pessoa bem técnica e que possa auxiliar na adaptação do sistema à realidade da empresa.

"Assim como no projeto há uma coordenação da empresa, há também uma coordenação feita pelo gerente de TI da empresa cliente. E o que se espera dessa pessoa é que ela auxilie na implantação do sistema e que também possa trazer e propor inovações". 
O entrevistado citou que uma das barreiras à inovação é o fato de todas elas terem que ser aprovadas pela matriz. De acordo com ele, há muita liberdade para que os funcionários tragam ideias de inovações, porém não há liberdade para que uma filial faça alterações em um processo, por exemplo, sem a prévia aprovação da matriz. No caso das duas inovações na metodologia de implantação de projetos, citadas pelo entrevistado, foi uma exceção à regra, pois ambas ainda estão em processo de aprovação pela matriz, mas já estão sendo utilizadas em Brasília.

"O tempo deste tipo de inovação costuma ser muito longo, principalmente por causa da necessidade de aprovação de São Paulo, pois tem que ser uma coisa padronizada para toda a empresa. Eles têm que analisar o que aquilo vai gerar, quais são os custos... Por exemplo, há seis meses dei uma sugestão de melhoria que até hoje está rodando".

Outra barreira advém das customizações nos sistemas, demandadas pelos clientes. Neste caso, sempre é feito um contrato com o cliente, especificando o que será customizado e o preço a mais que ele irá pagar por esta demanda. Mas, ainda assim, podem acontecer falhas de comunicação entre o vendedor e o cliente por problemas de escopo.

"Fechamos com o cliente antes do início do projeto de customização, no contrato, o que será entregado, nada além disso. Se houver algo além disso, será cobrado um adicional. Mas sempre acaba havendo uma falha de comunicação entre vendedor e cliente, o cliente geralmente falando que o vendedor disse que seria feito algo que não está no escopo".

\subsubsection{Identificação das fases de Sustentabilidade e Aprendizagem}

O entrevistado mencionou que uma inovação na empresa é sempre implementada com o objetivo de diminuir custos ou diminuir tempo. Citou como 
exemplo de impacto de uma inovação na empresa o fato de que a inserção da metodologia Scrum no processo vem contribuindo para diminuir a duração dos projetos. Em suas palavras, "um projeto de 100 dias cai para 80 dias mais ou menos com esta metodologia".

\subsubsection{Caso E}

O entrevistado do Caso $E$ trabalha na empresa há 10 anos e está há 4 anos no cargo de Diretor de TI.

A empresa do Caso $E$ é uma empresa de médio porte, com 14 anos de existência, e cujo maior foco de trabalho é a prestação de serviços, principalmente serviços de back-office bancário e fábrica de softwares. A maior parte dos clientes é composta pelo serviço público, chegando a cerca de $95 \%$ do total. Logo, o foco da empresa é em licitações.

Há cerca de 2 anos um de seus maiores clientes, um grande banco público, resolveu acabar com os serviços terceirizados de back-office. Nesta época, a empresa tinha um contrato de prestação de serviços de 4000 funcionários com este cliente. A cada ano, a empresa tinha que fazer uma repactuação dos valores pagos pelo cliente, pois o salário dos terceirizados sofria aumentos, devido a exigências do sindicato. Esta repactuação aconteceu corretamente por vários anos, mas costumava ser bastante complicada. Então, no momento da dispensa dos serviços da empresa, o cliente não pagou os valores de repactuação, que eram de aproximadamente $\mathrm{R} \$ 20$ milhões. Assim, a empresa não teve fôlego financeiro para pagar todas as rescisões dos funcionários que seriam demitidos, e, para não falir, entrou em regime falimentar de recuperação judicial, o que vem a ajudando a honrar, aos poucos, com seus compromissos.

A empresa está nesta situação até o presente momento, por isso sua maior estratégia hoje é a sobrevivência. Sendo assim, grande parte das inovações listadas pelo entrevistado foram anteriores ao acontecido. 
4.1.5.1 Identificação de casos de inovação

Há cerca de 5 anos, a presidência da empresa estabeleceu como visão o investimento em uma fábrica de softwares, por meio de processos padronizados, seguindo o padrão CMMI.

Uma das inovações ocorridas internamente para contribuir com esta visão foi a mudança na estrutura física de locação de pessoas. Cada funcionário tinha uma sala de produção particular com cerca de um metro e meio quadrado. Com isso, havia maior concentração e mais satisfação das pessoas com o trabalho.

Outra mudança feita para contribuir com a implantação dos processos foi na jornada de trabalho diária. Os funcionários têm um horário flexível, em que devem cumprir 40 horas semanais, começando, no mínimo, às 7:00 e terminando, no máximo, às 20:00, e tendo que tirar um intervalo de uma hora de descanso entre períodos de 6 horas de trabalho. A partir deste direcionamento, cada um monta seus horários. E o entrevistado, como diretor, controla os horários das pessoas por meio de um sistema chamado T-System, da Microsoft, que possibilita que o funcionário marque no sistema o horário em que começou e em que parou de trabalhar.

"Então eu sei quando ele estoura, quando ele começa antes do prazo, quando ele faz dentro do prazo... Então isso é outra inovação. Poucas empresas hoje conseguem ter um nível de controle tão alto em relação ao que é feito".

\subsubsection{Identificação das fases de Procura e Seleção de ideias}

As inovações citadas pelo entrevistado surgiram de uma visão da presidência em investir em tecnologia, criando a maior fábrica de softwares do país. Antes disso, a empresa fazia basicamente serviços de back-office bancário. Já havia na empresa um pequeno núcleo de desenvolvimento, então, com base nesta estrutura, foi criada a fábrica. 
Para as demais inovações que ocorrem na empresa, o entrevistado diz que é sempre a presidência que aprova os projetos, em conjunto com a diretoria. Ele diz que, "na realidade é feita uma votação, é quase como um comitê. Mas a decisão final é da presidência mesmo".

\subsubsection{Identificação da fase de Aquisição de conhecimentos}

A maioria dos conhecimentos necessários para a criação da fábrica de softwares não existia na empresa. Eram conhecimentos acerca de processos e certificações CMMI, que foram conseguidos por meio da contratação de consultorias.

\subsubsection{Identificação das fases de Execução e Lançamento da inovação}

De acordo com o entrevistado, uma das barreiras à ocorrência de inovações hoje é que, devido ao processo de recuperação judicial, alguns órgãos públicos não pagam os serviços já executados pela empresa. Como consequência, hoje a empresa possui contas a receber muito maiores do que as contas a pagar, mas, mesmo assim, isso ocasiona problemas de caixa para fazer certos pagamentos e impede a empresa de investir em inovação, pois não é a prioridade atual.

Com relação à execução do projeto de criação da fábrica de softwares na empresa, foram contratados consultores de Qualidade, que montaram todos os processos; e consultores de tecnologia, para desenvolver a parte de infra-estrutura.

Um problema citado durante a execução do projeto de criação da fábrica de software, há cinco anos, foi a dificuldade na implantação dos processos. Segundo o entrevistado, a utilização de processos requer uma mudança drástica dentro da organização, já que é necessário que os funcionários sigam todas as rotinas dos processos, inclusive justificando atrasos na execução de suas atividades.

"Primeiro que eu conheço poucas empresas que usam processo de verdade. A gente vê aí que quase toda empresa que participa de licitação tem ISO. Eu falo sem 
pestanejar, menos de $10 \%$ seguem. Acham uma empresa certificadora, pagam, ela certifica tudo, mas no dia-a-dia ela não executa aquilo daquela forma. Acho que é cultural".

Outro problema na utilização de processos é que os custos são relativamente altos. Além disso, na implantação, ocorreu de os funcionários despenderem muito tempo executando os procedimentos dos processos, deixando de efetivamente trabalhar e gerar resultados.

"Em alguns momentos, alguns processos nossos foram medidos e geravam um overhead de $40 \%$. Ou seja, do dia da pessoa, $40 \%$ do tempo era tocando processos, e os outros $60 \%$ era efetivamente trabalhando, fazendo o que ela tinha que fazer para gerar o produto do cliente".

$\mathrm{Na}$ inovação obtida com a diferente estruturação das salas de produção dos funcionários, também surgiu um problema: o objetivo de aumento da concentração dos funcionários não foi concretizado.

"Aí a gente esbarra de novo no aspecto cultura, a gente está no Brasil. Brasileiro não tem jeito, conversa muito. Daqui a pouco estava todo mundo com as portas abertas. Então, culturalmente eu questiono um pouco isso daqui. Outra coisa, em alguns projetos, a gente teve que desmontar isso e colocar em uma sala junta. Se você tem um projeto que precisa ser feito rapidamente, que as pessoas têm que absorver informação com muita velocidade e sair um produto com velocidade, o modelo das salinhas não favorece muito".

Outro problema na implantação, que o entrevistado também relacionou à cultura, é que os funcionários esqueciam de marcar no sistema T-System o momento em que começavam a trabalhar. 
"A gente tinha problema para o desenvolvedor ir ao sistema e marcar que tinha começado a trabalhar. Pode parecer bobo, mas isso aí é um pilar. Como é que eu vou saber o que ele produziu, como é que eu vou quantificar aquele projeto se ele não marcou que estava trabalhando? E o pagamento dele é feito baseado no que ele trabalha, ainda tem isso. Mesmo assim, esquecia".

\subsubsection{Identificação das fases de Sustentabilidade e Aprendizagem}

A questão das melhorias na inovação pode ser observada quando o entrevistado diz que, em um primeiro momento, não conseguiram implementar os processos na empresa, mas que, em uma segunda tentativa, tiveram sucesso, conseguiram englobar a nova cultura baseada em processos e o projeto desenvolveu-se bem.

"Nós tivemos uma parada, uma ruptura em determinado momento, onde nós pegamos e retomamos. Teve algumas adaptações, alguns ajustes, e neste momento já foi mais fácil, porque já tinha um serviço auto executado. Foi como eu falei para você, num primeiro momentos as pessoas tentaram tirar certificação, e num segundo momento a gente incorporou o processo pra fazer de verdade".

Com relação à coleta de lições aprendidas, o entrevistado diz que o projeto em si já prevê momentos para isso. A própria certificação CMMl exige. Na empresa existe um sistema chamado Share Point, que é uma ferramenta tecnológica onde são lançadas as lições aprendidas. Então, o próprio processo dá suporte à reutilização do conhecimento.

Porém, o entrevistado cita que a cultura de lições aprendidas é muito forte na área de tecnologia, mas não no restante da organização.

"Hoje um dos problemas dessa empresa e de algumas outras que eu conheço é que o conhecimento fica na cabeça das pessoas. Isso é ruim. Por isso que você citou as lições aprendidas. As lições aprendidas são uma forma de você tirar parte 
do conhecimento da cabeça das pessoas. E essa empresa ainda tem isso. Essa parte de processos é muito forte aqui na área de tecnologia, no restante da empresa não é".

\subsubsection{Caso F}

O entrevistado do Caso $\mathrm{F}$ teve como último cargo na empresa o de Diretor de Arquitetura de Soluções. Trabalhou diretamente na empresa durante 13 anos, sendo 7 anos em cargos de diretoria. Há cerca de um ano, foi convidado para trabalhar em um instituto em que uma das mantenedoras é a empresa do Caso F. Seu atual cargo neste instituto é de Diretor de Pesquisa e Desenvolvimento e sua função é a de estudar novas tecnologias que ainda não estão disponíveis no Brasil.

A empresa do Caso $F$ foi constituída em Goiânia e hoje a matriz situa-se em Brasília. É uma Sociedade Anônima desde 2007 e possui um faturamento anual em torno de \$200 milhões. Em seu quadro atuam cerca de 5000 funcionários. Foi a primeira empresa do país a tirar a certificação CMMI nível 5.

A empresa possui dois principais segmentos de atuação. Uma vertente é a de consultoria, comercialização, capacitação e treinamento em ERP. Na outra vertente estão os serviços especializados de $\mathrm{TI}$, em que a empresa atua desde $\mathrm{O}$ desenvolvimento, teste, manutenção, implantação e suporte, tanto na modalidade de outsourcing quanto na de fábrica de software. Alguns dos clientes da empresa são Petrobrás, Caixa Econômica, Banco do Brasil, Ministério do Trabalho, Ministério da Justiça.

\subsubsection{Identificação de casos de inovação}

Um caso de inovação citado pelo entrevistado foi a implantação da fábrica de softwares na empresa, considerada um divisor de águas na forma como a empresa prestava serviços até então, que se dava basicamente por meio de outsourcing, ou alocação de mão-de-obra. Na época, em 1996, a demanda pelo mercado de mão- 
de-obra alocada ainda era bastante elevada, mas a empresa viu nesta inovação uma oportunidade de se diferenciar perante os concorrentes.

"Foi um diferencial para o cliente não ter que chegar e dizer assim: 'Todo mundo aqui faz alocação?' Faz. 'Quanto custa a alocação de vocês?' A minha custa 10, a minha custa 9,90 e a minha custa 9,30... 'Ah! Então eu vou comprar a de 9,30'. Então, para evitar a comoditização, dissemos assim: Eu faço de um jeito diferente que eles não conseguem fazer e eu posso te oferecer indicadores diferentes".

A decisão de adotar um modelo de qualidade de padrão internacional foi outra inovação indispensável em que a empresa investiu e que acabou sendo um sinalizador muito forte para mercado, visto que uma série de instituições, inicialmente as públicas, passou a exigir em editais a certificação CMMI.

A empresa foi também precursora na utilização de workflow, em um momento em que as empresas não entendiam a necessidade de estruturação de seus fluxos de trabalho. Nas palavras do entrevistado, esta inovação surgiu "em uma época em que todo mundo dizia que 'quem precisa é meu vizinho, eu não preciso de workflow, para mim meu fluxo administrativo está ótimo, está excelente'”.

\subsubsection{Identificação das fases de Procura e Seleção de ideias}

O principal fator que justifica a constante busca da empresa por inovações é o incentivo dos sócios. A visão disseminada pelos sócios sempre é a de que a empresa deve estar a pelo menos um passo a frente dos concorrentes, em todos os momentos. Então, com esta visão, a empresa sempre buscou investir em diferentes segmentos que pudessem caracterizar a inovação em serviços. Como comprovação de que esta é uma visão compartilhada na empresa, o entrevistado cita que, em 1991, a empresa já falava em workflow; em 1994, em gerenciamento eletrônico de documentos; em 1997, em digitalização e reconhecimento inteligente de caracteres; entre outras inovações ainda pouco divulgadas no Brasil na época. 
O entrevistado cita que a etapa inicial do modelo de inovação utilizado na empresa consiste em uma análise do mercado, procurando tecnologias e soluções relacionadas ao negócio da empresa. O processo de determinar quais tecnologias tem alguma relação com a empresa é um processo empírico, baseado na experiência dos profissionais envolvidos e nos valores que a empresa compartilha. Após a coleta de várias oportunidades de melhoria, as ideias são levadas à diretoria colegiada, para que escolham aquelas que devem ser transformadas em projetos.

"O modelo nosso é um funil. No primeiro funil pode entrar qualquer coisa. A gente obviamente faz um filtro e leva para decisão da diretoria colegiada. Lá eles dizem assim: 'Não, a gente acha que essa tecnologia, essa e essa são as mais promissoras. Saindo dali, a gente pega essas três tecnologias e aí faz um estudo mais aprofundado".

Alguns dos critérios utilizados para se analisar mais profundamente as tecnologias são: estudo do mercado em que a tecnologia é aplicada, taxa de crescimento desta tecnologia, tempo de desenvolvimento, custos envolvidos e estimativa de lucratividade.

Houve situações na empresa em que os próprios clientes demandaram inovações que acabaram sendo implementadas. Porém, no geral, as inovações surgem dentro da própria empresa. Com as citações abaixo, o entrevistador justifica este fato:

"Até porque tem uma visão que faz parte do conjunto de crenças e valores que a gente tem que é o seguinte: se você chegar para um cliente, sentar na frente dele e perguntar assim: 'Qual é o seu problema?', o cliente vai virar e dizer assim: 'Eu não tenho problema'. Você perdeu duplamente a oportunidade. Primeiro, você perdeu cinco minutos de atenção que aquele cliente te deu para aquela oportunidade comercial, e segundo, você fez a pergunta errada”.

"Então, a crença que a gente tem é que quando você tiver uma oportunidade com o cliente, você tenha previamente feito o seu dever de casa de dizer assim: 
'Olha, eu analisei o seu segmento, eu analisei a sua empresa e eu acho que eu posso te ajudar nesta área, eu acho que eu posso melhorar em tantos por cento a maneira como você emite cartão de crédito, por exemplo. Aí você está falando a língua dele, a língua de negócios. Agora, chegar para oferecer banco de dados, programação, você está muito restrito a uma área que cada vez está perdendo força, que é a área de tecnologia".

\subsubsection{Identificação da fase de Aquisição de conhecimentos}

Um fator vital para o desenvolvimento das inovações na empresa foi a implantação de um programa de bolsas de mestrado em conjunto com a Universidade Católica. Foram criados acordos junto aos professores orientadores para que os trabalhos fossem realizados utilizando a empresa como laboratório. Em 2003, foi fechada uma turma de mestrado em Gestão de Conhecimento e Tecnologia da Informação em que, dos 22 alunos, 14 eram funcionários da empresa. O investimento foi de $R \$ 1200,00$ por bolsa.

Com esta ação, durante três anos seguidos a empresa ganhou o prêmio de melhor trabalho de pesquisa pela Sociedade Brasileira de Qualidade de Software (SBQS). Várias inovações surgiram dos projetos de pesquisa realizados pelos estudantes.

\subsubsection{Identificação das fases de Execução e Lançamento da inovação}

Com relação aos atores engajados na inovação, o entrevistado acredita que não existem empresas onde todas das pessoas são inovadoras. Para ele, é na cúpula da empresa, dentre os tomadores de decisão, que devem estar as pessoas "inconformadas com a forma como as coisas são executadas".

"Agora eu, pessoalmente, eu sei que existem correntes que acreditam que a empresa inovadora é aquela onde todos contribuem. Eu não consegui ver isso. Um 
exemplo que eu dou é o seguinte, nós fizemos um artigo muito interessante para nosso jornal interno e no final do artigo a gente colocou um endereço de e-mail que dizia assim: qualquer pessoa que tiver uma ideia sobre alguma coisa que possa ser melhorada, não importa quão absurda seja, mande. Eu vou receber, eu vou estudar cada uma delas e eu vou te responder. Soltamos o informativo, 7000 exemplares.

Nós tivemos seis contribuições. Está ótimo. Quatro viraram oportunidades de negócio".

Quando se trata de cooperação com agentes externos para a criação de inovações, o entrevistado menciona a dificuldade no relacionamento com institutos fomentadores:

"Na área governamental, nos institutos fomentadores, como FINEP, CAPES, CNPQ, existia um gap muito grande entre o que eles entendiam que era inovação e o que eles estavam dispostos a investir, e o que a gente entendia que era inovação

e o que a gente estava disposto a investir. Segunda questão, o processo era construído de uma maneira que você não conseguia levar seu projeto até o final. $\mathrm{O}$ volume de barreiras, as exigências, a maneira de se escrever... Nós tentamos umas quatro vezes. Em três, fomos mal-sucedidos e a vez em que a gente conseguiu, quando chegou na última etapa, acabou a verba para fomentar. Então, uma boa parte, eu diria mais de noventa por cento de todos os esforços de inovação, se deram a partir do investimento interno da empresa".

Como principal barreira à inovação, o entrevistado cita a dificuldade de aceitação da mudança por parte das pessoas.

"É por isso que eu digo, um cuidado muito grande que você tem que ter quando inicia um projeto de inovação é ter nesse projeto somente pessoas inovadoras, pessoas que estão dispostas a quebrar a cara... que acreditaram, só que o negócio não foi do jeito que se esperava. Porque se você tiver uma pessoa avessa à mudança, o projeto está fadado ao insucesso". 
4.1.6.5 Identificação das fases de Sustentabilidade e Aprendizagem

A preocupação com a sustentabilidade das inovações pode ser observada por meio da seguinte citação do entrevistado:

"Então, o foco da empresa é sempre o quê: serviços que tragam receita recorrente. Então nunca foi o objetivo vender 10 mil computadores, receber um monte de dinheiro e levar mais um ano e meio para fazer uma nova venda. Não, era melhor receber 100 mil por mês durante dois anos do que 1 milhão no primeiro mês.

Quer dizer, a visão é sempre de longo prazo com relação a taxa de crescimento".

Esta busca de modelos diferenciados foi essencial inclusive para a internacionalização da empresa. A oferta de serviços que a empresa possui hoje nos Estados Unidos, Argentina, Chile e Japão estão calcadas nesta percepção de qualidade, que foi possível apresentar aos times técnicos que avaliaram e certificaram, na época da internacionalização, que a empresa tinha capacidade de atender ao nível requerido de qualidade destes países.

Outra observação da sustentabilidade de uma inovação a longo prazo mostra-se no momento em que a empresa tirou a certificação CMMI nível 5. Os custos diretos com este projeto, que durou 5 anos, foi inferior a $R \$ 600.000,00$, um gasto considerado baixo. Mas os custos indiretos - horas de treinamento, escrita de procedimentos, perda de produtividade dos funcionários por estarem trabalhando daquela maneira pela primeira vez - foram cerca de 4 vezes o valor dos custos diretos. Em compensação, o resultado desta inovação para a empresa é estimado em 10 vezes o valor dos custos diretos, no mínimo, no primeiro ano após a certificação nível 5.

“Então, não há dúvida de que quando você acerta a linha de inovação e isso é importante para a empresa, o retorno é como uma venture capital: você tem um retorno de 10, 20, 50 vezes o que você investiu". 


\subsection{Análise dos Casos}

\subsubsection{Confrontação das inovações relatadas em cada caso com os tipos de inovação}

Uma importante ressalva que faz Gallouj (2002) é que os tipos de inovação não são sempre desconectados. Além disso, as terminologias utilizadas para identificar cada tipo de inovação podem trazer certa ambiguidade, já que contêm julgamento do grau de novidade ou de originalidade da inovação, uma análise até certo ponto subjetiva. Ainda assim, o mais importante é que estes seis modelos trazem à tona a existência de diferentes dinâmicas de características que definem cada uma das inovações. Partindo deste pressuposto é que foram analisados os tipos de inovação contidos em cada caso, de acordo com os seis modelos propostos por Gallouj (2002, 2007).

No conjunto das empresas estudadas, foi possível observar a ocorrência de todos os seis tipos de inovação.

A inovação radical foi observada em quatro casos. No caso A com a Ferramenta GVE, que se mostra um produto inteiramente novo em que todos os vetores de características e competências de Gallouj - [C'], [C], [T], [Y] - são substituídos, já que o produto criado é totalmente diferente do anterior - no caso, a forma como ocorre hoje a coleta de larvas do mosquito da dengue nas casas da população. É importante enfatizar que as competências do cliente - neste caso, o agente de saúde e o cidadão - são também modificadas, já que o agente de saúde precisará da habilidade de manusear uma ferramenta tecnológica nova e o cidadão poderá utilizar o ambiente do cidadão.

No Caso $\mathrm{B}$ a inovação radical foi observada em três momentos. O primeiro, na utilização da ferramenta cloud computer, em que os vetores [C'], [C] e [T] são substituídos, porém o produto final $[\mathrm{Y}]$ permanece o mesmo. O produto final, neste caso, é a armazenagem de dados. 
A segunda inovação radical é a ferramenta de Mobilidade desenvolvida para a Caixa Econômica, que é algo pioneiro no mercado.

A terceira inovação radical do Caso B é a nova concepção adotada para a oferta de serviços da empresa, visto que ela antes enfocava no outsourcing e passou a fornecer o serviço de gerenciamento de servidores de forma diferente. A verificação da inovação radical do Caso $\mathrm{F}$ com a implantação da fábrica de softwares representa exatamente a mesma mudança na concepção de serviços apresentada no Caso B. Nos dois casos os vetores [C'], [C] e [T] são substituídos. O produto final [Y] também é novo, já que a forma como se fornece o serviço final é diferente, ou seja, o foco deixa de estar na alocação de mão-de-obra e passa a estar no gerenciamento de servidores do cliente.

No Caso C, a inovação radical ocorreu com o início da atuação da empresa em um novo ramo. Como a empresa não trabalhava com soluções para a indústria e teve que se capacitar por meio de novas tecnologias e competências para criação do novo produto, pode-se caracterizar esta mudança como uma inovação radical.

Inovações pela melhoria foram observadas em três casos. No Caso C, a mudança na forma como as dúvidas dos clientes eram sanadas pelo service desk constitui uma melhoria na qualidade do atendimento, sem o acréscimo de novo conjunto de características dos vetores. No Caso D, as melhorias nas funcionalidades dos softwares foram obtidas por meio de um aumento de qualidade nas características técnicas [T]. No Caso E, o produto final [Y] da mudança na estrutura física de locação de pessoas era a obtenção de um ambiente de trabalho mais produtivo. Ou seja, as mudanças trouxeram aumento de qualidade do trabalho, sem a necessidade de diferentes características de vetores. O mesmo raciocínio pode ser utilizado para a inovação pela flexibilização da jornada de trabalho do Caso E.

As inovações incrementais ocorreram nos Casos D e E, pois em ambos houve adição de características [T] ou [C], modificando marginalmente o produto [Y]. No Caso D, observou-se o acréscimo de duas novas técnicas à metodologia de implantação de sistemas já existente. Estas técnicas foram a introdução de indicadores NPS e a introdução da metodologia Scrum. O vetor [T] que já existia antes, que era a utilização da metodologia do PMBOK neste processo manteve-se. No Caso E, a inovação incremental surgiu com a inserção de uma nova 
característica [T], o sistema T-System, como ferramenta de controle da produtividade.

A inovação ad hoc foi observada somente no Caso $B$, pois a ferramenta de Mobilidade desenvolvida para a Caixa surgiu de uma demanda particular do cliente e foi elaborada especificamente para ele. E esta inovação também contribuiu para que a empresa produzisse competências na área de Mobilidade. Este foi o único caso de inovação que foi caracterizado em dois tipos de Gallouj: como inovação radical e ad hoc.

A inovação pela recombinação foi observada apenas no Caso $C$, com a criação da ferramenta Office2 CRM. Isso porque esta inovação baseou-se em características existentes de outros produtos; por exemplo, o sistema ERP de uma empresa pode ser utilizado para se fazer a integração de dados com o sistema utilizado por sua contabilidade terceirizada. Assim, o Office 2 CRM utiliza-se de competências e tecnologias vindas de outros produtos.

Com relação às inovações pela formalização, no Caso $A$ e no Caso $F$ foi observada a busca de certificações de Qualidade, como CMMI e ISO, pois são normas que demandam uma padronização dos procedimentos das empresas. No Caso F observa-se também este tipo de inovação com a utilização de workflow, que visa a padronização e mapeamento dos processos da empresa.

O Quadro 2 mostra um resumo dos tipos de inovações relatados em cada caso. 


\subsubsection{Análise das fases de Procura e Seleção de ideias}

Normalmente as ideias surgem dentro da própria empresa na maioria dos casos. Os entrevistados do Caso A e C citam que a inovação pode surgir em momentos informais dos funcionários.

O entrevistado do Caso D é o único a citar que, apesar de a empresa ser muito aberta a propostas de inovações, o processo de seleção das inovações é bastante demorado, pois todas as inovações dependem de aprovação da matriz.

Nos Casos B, E e F, as decisões de investir ou não em uma inovação vêm da alta cúpula das empresas. No Caso B acontece de o Conselho Deliberativo convidar algumas pessoas chave da organização para participarem da tomada de decisão. Já no Caso C, não é a diretoria que tem o papel de selecionadora de inovações, e sim o corpo técnico, formado pelos programadores e analistas de software.

O Caso $F$ foi onde ficou mais explícita a abertura da empresa para que os funcionários tragam sugestões de inovações. Foi também nesta empresa que se observou mais claramente como ocorre o processo de tomada de decisão pela diretoria colegiada e quais são os critérios de decisão utilizados.

Foram observadas práticas de fomento à inovação nos Casos A e F: a denominada Reunião do Nada do Caso A; e o jornal interno do Caso F, que continha um endereço de e-mail para que os funcionários sugerissem mudanças.

Um fato interessante que pode ser observado também nos Casos A e F é a forte percepção das empresas de que a tecnologia é somente uma das ferramentas utilizadas para se cumprir o objetivo maior, que é a resolução de um problema do cliente.

Um ponto observado no Caso $C$ é que as inovações nesta empresa não costumam surgir por meio de estudos de tendências do mercado, ou interesses específicos na empresa. Elas surgem de forma mais reativa, frente a uma necessidade de um cliente específico. Como exemplo, pode-se citar a entrada da 
empresa no ramo industrial, cujo impulso para a inovação surgiu de demandas recorrentes de possíveis clientes.

Grande preocupação com a procura e seleção de inovações pode ser observada na empresa do Caso A, que recentemente criou em sua estrutura a Coordenação de Inovação Tecnológica, um departamento que visa estudar e estruturar as ideias propostas.

\subsubsection{Análise da fase de Aquisição de conhecimentos}

De acordo com o relato do entrevistado, a empresa do Caso A não se limita aos conhecimentos que tem quando o meio externo não disponibiliza as informações. Nestas situações, é formado um grupo de pesquisa interno para fomentar novas competências.

Nos Casos $\mathrm{B}$ e $\mathrm{F}$ foi possível observar o incentivo das empresas à obtenção de conhecimentos por meio do fornecimento de bolsas para retirada de certificação ou para Mestrado.

O uso de tecnologia para obtenção de conhecimentos foi observada no Caso C, por meio da utilização do sistema ITIL. Também no Caso C é interessante notar a existência de um centro de treinamentos, dos mesmos sócios, especializado em treinar os funcionários da empresa nos sistemas por ela desenvolvidos.

\subsubsection{Análise das fases de Execução e Lançamento da inovação}

Um relato de cooperação com fornecedores observado no Caso A foi o acordo comercial feito com uma empresa chinesa para a produção dos equipamentos que compõem a inovação GVE. A empresa do Caso A também faz acordos de cooperação técnica com várias universidades do país. Pode-se citar o engajamento da empresa com a Universidade Católica no desenvolvimento de uma solução conjunta. 
A cooperação com outras empresas também é observada no Caso $B$, em que há um contrato de exclusividade com uma empresa especializada em soluções de dispositivos móveis.

Já no Caso D, há forte colaboração entre a empresa e seus clientes, já que o cliente geralmente possui internamente um Gerente de TI que auxilia na implantação dos projetos e sugere melhorias.

A barreira à inovação mais recorrente, citada pelos Casos $A, C$ e $F$, é a resistência ao novo. Apesar de as outras três empresas não terem deixado isso explícito, pode-se inferir por seus relatos que também consideram a resistência a mudanças um fator prejudicial.

A empresa do Caso B citou que, muitas vezes, o próprio fornecedor pode criar barreiras com a introdução de uma nova tecnologia. Conseguir aprovação de inovações por parte do Conselho também é um problema no Caso $B$, pois os sócios são bastante conservadores quando se trata de grandes investimentos.

Uma barreira citada de forma recorrente no Caso E é a questão cultural, vista pelo entrevistado como um motivo pelo qual não foi possível a implantação de certos processos na empresa em um primeiro momento.

Um fato interessante relacionado aos órgãos financiadores e fomentadores de inovações é que nos Casos $A$ e $F$ são citados relatos de insatisfação com este serviço, devido a motivos diversos: burocracia no processo e priorização de projetos com base em critérios pouco estruturados foram os mais citados. As duas empresas utilizam-se de recursos próprios no desenvolvimento de inovações.

\subsubsection{Análise das fases de Sustentabilidade e Aprendizado adquirido com a inovação}

O entrevistado do Caso $A$ afirmou que melhorias às inovações, principalmente quando se fala em tecnologia, devem ocorrer constantemente. Na empresa do Caso A, quando a equipe de produção está trabalhando na primeira versão de um projeto, a equipe de desenvolvimento já está desenvolvendo sua segunda versão. A 
empresa possui, ainda, um relatório de problemas que aconteceram ao longo da execução do projeto de pesquisa.

No Caso A e no Caso B a preocupação com a sustentabilidade de uma inovação pode ser observada com a criação de empresas para aquelas inovações que prosperam, o que simboliza uma melhoria na inovação existente.

No Caso $B$, com relação à coleta de lições aprendidas geradas pelas inovações, há reuniões periódicas para análise dos resultados gerados por uma inovação.

No Caso C pode ser observada a utilização da ferramenta tecnológica ITIL para controle das lições aprendidas. O mesmo ocorre no Caso $E$, em que se utiliza o sistema Share Point.

Podem ser observados impactos positivos de inovações na lucratividade das empresas nos Casos B, D e F. Outro impacto da inovação no Caso F foi a internacionalização da empresa, que se deu a partir das inovações obtidas com as certificações de Qualidade da empresa e com a utilização de workflow. 


\section{CONCLUSÕES E RECOMENDAÇÕES}

Este estudo teve por objetivo descrever como ocorre o processo de gestão da inovação em empresas prestadoras de serviços de software do Distrito Federal, caracterizando também os tipos de inovação observados em cada um dos seis casos analisados.

Os resultados obtidos a partir dos casos mostram que as empresas de serviços de software possuem mecanismos, mesmo que informais, de gestão da inovação. Percebe-se que as empresas nem sempre utilizam uma estruturação completa do processo de gestão da inovação englobando todas as fases do modelo teórico de Tidd, Bessant e Pavitt (2008), mas que isso muitas vezes é um desejo da própria organização, que não compartilha a visão de uma inovação totalmente controlada por processos formalizados.

$\mathrm{Na}$ caracterização das inovações, são relatadas melhorias em sistemas existentes, criação de ferramentas tecnológicas totalmente novas, novos segmentosalvo de atuação, melhorias nos processos, melhorias na forma de atendimento ao cliente e aquisição de certificações. Todos os tipos de inovação propostos por Gallouj $(2002,2007)$ puderam ser analisados.

As inovações mais recorrentes foram inovações radicais, presentes em quatro das seis empresas deste estudo. Nelas, observaram-se tanto inovações radicais que geraram produtos totalmente novos, quanto inovações radicais que mantêm as características do produto final, mas substituem as características técnicas e as competências que o criam.

Menos comuns foram as inovações pela recombinação e ad hoc, em que somente um caso foi identificado para cada uma. Foi possível observar uma inovação que se caracterizou tanto como inovação radical quanto como inovação ad hoc, já que, além de ser um produto pioneiro no mercado, foi desenvolvido em conjunto com o cliente, visando solucionar um problema particular.

Apesar de todas as empresas dos casos buscarem certificações como ISO e $\mathrm{CMMI}$, apenas nos casos A e F elas foram citadas como inovações, caracterizando as inovações pela formalização. 
Os resultados apontam que as fases de procura e seleção de inovações não costumam ter momentos específicos de ocorrência e geralmente estão atreladas às atividades da cúpula da empresa, não sendo uma atividade cuja participação de todos os níveis empresariais mostra-se visível.

O resultado obtido com a análise da fase de aquisição de conhecimentos é que ela ocorre de maneiras diferenciadas nas empresas, mas igualmente promissoras. Pode-se observar que é comum às empresas a utilização de conhecimentos desenvolvidos internamente, bem como a ocorrência de convênios com universidades visando à capacitação dos profissionais. Observam-se também casos de utilização de ferramentas tecnológicas de acumulação e disseminação de conhecimentos.

$\mathrm{Na}$ análise das fases de execução e lançamento da inovação, foi recorrente o fato de que a principal barreira à inovação é a resistência a mudanças, que muitas vezes se dá dentro da organização, mas também pode ocorrer na aceitação de produtos novos pelos clientes. Há relatos de que os projetos de inovação devem envolver apenas pessoas abertas a mudanças, pois aquelas muito conservadoras e avessas ao risco podem acabar fadando um projeto ao insucesso.

Outra constatação preocupante foi a de que as empresas, para inovar, costumam utilizar-se de recursos próprios, visto que não consideram acessíveis as formas de financiamento propostas por órgãos fomentadores e julgam os critérios de priorização de projetos feitos por estes órgãos pouco justos.

Os resultados mostram também uma preocupação das empresas de serviços de software cada vez maior com a apresentação de soluções completas para os problemas dos clientes, mais do que com a venda de tecnologia em si.

Em síntese, pode-se concluir que este estudo acarretou no surgimento de uma proposta inicial de modelo de gestão da inovação aplicável às empresas de serviços de software. Esta constatação surgiu como decorrência dos blocos temáticos concebidos pela autora e apresentados na seção de Métodos e Técnicas de Pesquisa, visto que foi possível verificar como as empresas de software gerem a inovação em cada uma das cinco etapas dos blocos temáticos criados. Com isso, apesar de a base para a criação dos blocos temáticos ter sido o modelo genérico de gestão da inovação proposto por Tidd, Bessant e Pavitt (2008), o estudo apresentou 
indícios que podem sugerir a construção de um modelo menos genérico e adaptável à realidade das empresas deste setor, e que pode ser mais explorado e mais desenvolvido em pesquisas futuras.

Com os resultados apresentados, mostra-se que o trabalho conseguiu atingir seu objetivo inicial de analisar os modelos de gestão da inovação adotados por empresas de serviços de software atuantes no Distrito Federal. Além disso, o estudo também possibilitou investigar teoricamente os modelos existentes relacionados ao processo de gestão da inovação e buscar um modelo que representasse de forma apropriada a dinâmica do setor de serviços de software, que foi o modelo de gestão proposto por Tidd, Bessant e Pavitt (2008). O trabalho também atingiu seus objetivos específicos de identificar casos de inovações nas empresas de softwares e caracterizá-los com base nos tipos de inovação propostos por Gallouj $(2002,2007)$.

Apesar de não fazer parte dos objetivos deste trabalho, constatou-se ser possível analisar, por meio das descrições de cada caso, a estratégia de inovação adotada pelas empresas. Portanto, em futuras pesquisas complementares ao estudo sugere-se aprofundar a análise, identificando qual a estratégia adotada por cada organização, bem como a relação entre a forma como a inovação ocorre nas empresas estudadas e o tipo de estratégia seguida.

Como perspectivas para pesquisas futuras que se baseiem no modelo de gestão proposto por Tidd, Bessant e Pavitt (2008), abre-se a possibilidade de utilizar, na análise dos tipos de inovação de cada empresa, as quatro categorias propostas por estes mesmos autores, também chamadas de "4Ps" - inovação de produto, inovação de processo, inovação de posição e inovação de paradigma -, relacionando-as com as dimensões da inovação, que vão desde melhorias incrementais menores até mudanças realmente radicais. Este pode ser um caminho para que estudos futuros obtenham uma visão completa da gestão da inovação analisada pelo ponto de vista dos mesmos teóricos.

Outra recomendação para futuras pesquisas é a replicação deste estudo ainda dentro do setor de softwares, porém analisando este setor em outras localidades, visto que, na maioria das empresas deste estudo, o principal cliente é o governo, já que as empresas se localizam em Brasília. Com isso, parte das inovações tende a seguir o que é demandado pelos órgãos públicos. Em outras cidades, a dinâmica 
geral da inovação pode acontecer de formas diferentes, a depender dos setores em que se encontram os principais clientes.

Fica como sugestão, ainda, a possibilidade de replicação deste estudo em outros setores de serviços como uma forma de contribuir para a própria formação dos conhecimentos sobre a dinâmica da gestão da inovação em serviços.

Conclui-se, por fim, que o setor de serviços de software está sofrendo um processo de mudança em seu modelo de negócio, visto que, nos dias atuais, não é mais lucrativo oferecer aos clientes apenas soluções tecnológicas, sem uma análise do contexto geral em que se insere a empresa cliente. As empresas de serviços de software precisam compreender a importância desta nova forma de ação voltada à solução de problemas e disseminar esta nova visão de negócio a todos os seus níveis hierárquicos. E, para que este processo de mudança possa ocorrer, é imprescindível que se invista tempo e recursos na capacitação dos profissionais e no desenvolvimento de inovações. 


\section{REFERÊNCIAS}

ABES - ASSOCIAÇÃO BRASILEIRA DAS EMPRESAS DE SOFTWARE. Mercado Brasileiro de Software - Panorama e Tendências. São Paulo, 2009. Disponível em: <http://www.abes.org.br/UserFiles/Image/PDFs/Mercado_BR2009.pdf>. Acesso em: 22 jun. 2010.

BRASIL. Lei ํㅜ 10.973, de 2 de dezembro de 2004. Dispõe sobre incentivos à inovação e à pesquisa científica e tecnológica no ambiente produtivo. Diário Oficial da União, Poder Executivo, Brasília, DF, 13 out. 2005. Disponível em: <http://www.planalto.gov.br/ccivil_03/_ato2004-2006/2005/Decreto/D5563.htm>. Acesso em: 12 mai. 2010.

BRASIL. Lei oํ 11.196, de 21 de novembro de 2005. Dispõe sobre incentivos fiscais para a inovação tecnológica. Diário Oficial da União, Poder Executivo, Brasília, DF, 22 nov. 2005. Disponível em: <https://www.planalto.gov.br/ccivil_03/_Ato20042006/2005/Lei/L11196.htm>. Acesso em: 12 mai. 2010.

CÂMARA DOS DEPUTADOS. O Mercado de Software no Brasil: Problemas Institucionais e Fiscais. Caderno de Altos Estudos, Brasília, n. 3, 2007.

CORAL, E.; OGLIARI, A.; ABREU, A. F. Gestão Integrada da inovação: estratégia, organização e desenvolvimento de produtos. São Paulo: Atlas, 2009. Cap. 1, p. 113.

DAVILA, T.; EPSTEIN, M. J.; SHELTON R. As Regras da Inovação: como gerenciar, como medir e como lucrar. Porto Alegre: Bookman, 2007. Cap. 2, p. 4876, Cap. 5, p. 134-156.

FACHIN, O. Fundamentos de Metodologia. São Paulo: Saraiva, 2002. Cap. 2, p. $42-45$.

FLICK, U. Uma introdução à Pesquisa Qualitativa. Porto Alegre: Bookman, 2004. Cap. 8, p. 104-108, Cap. 15, p. 188-207.

GADREY, J. Emprego, produtividade e avaliação do desempenho dos serviços. In: SALERNO, M. S. (Org.). Relação de Serviço: produção e avaliação. São Paulo: SENAC, 2001. Cap. 1, p. 23-65. 
GALLOUJ, F. Economia da Inovação: um Balanço dos Debates Recentes. In: ANDREASSI, T.; BERBARDES, R. (Org.). Inovação em Serviços Intensivos em Conhecimento. São Paulo: Saraiva, 2007. Cap. 1, p. 3-24.

GALLOUJ, F. Innovation in the Service Economy: The New Wealth of Nations. Cheltenham: Edward Elgar, 2002. Cap. 2, p. 28-69, Cap. 3, p. 70-104.

GIL, A. C. Como elaborar projetos de pesquisa. São Paulo: Atlas, 1996. Cap. 10, p. 121-125.

GRÖNROOS, C. Marketing: Gerenciamento e Serviços. Rio de Janeiro: Campus, 1993. Cap. 2, p. 33-63.

HIPP, C.; GRUPP, H. Innovation in the service sector: The demand for servicespecific innovation measurement concepts and typologies. Research Policy, Germany, v. 34, p. 517-535, 2005.

IBGE. Comentários Gerais. Pesquisa Anual de Serviços, Rio de Janeiro, v. 9, p. 34-40, 2007.

IBGE. Sistema de Contas Nacionais: Brasil 2003-2007, Rio de Janeiro, n. 27, p. 17-19, 2009.

KON, A. Economia de Serviços: Teoria e Evolução no Brasil. Rio de Janeiro: Editora Elsevier, 2004. Cap. 1, p. 1-20, Cap. 2, p. 23-43.

MOREIRA, M. F. Quando o Governo é o Mercado: Compras Governamentais e Inovação em Serviços de Software. Brasília: PPGA, 2009.

ROTHWELL, R. Towards the Fifth-generation Innovation Process. International Marketing Review, Reino Unido, v. 11, n. 1, p. 7-31, 1994.

SAMPIERI, R. H.; COLLADO, C. F.; LUCIO, P. B. Metodologia de Pesquisa. São Paulo: Editora McGraw-Hill, 2006. Cap. 9, p. 284-410, Cap. 10, p. 412-525.

SEPIN. Pesquisa de Qualidade e Produtividade no Setor de Software Brasileiro, Brasília, 2005.

SOUSA, S. V. A. Contrapontos e Similaridades entre o Desenvolvimento da Indústria de Software no Brasil e no Mundo. Revista de Administração Unime, Bahia, v. 2, n. 1, jan./jul. 2004. Não paginado. 
SUNDBO, J. Management of Innovation in Services. The Service Industries Journal, Londres, v. 17, n. 3, p. 432-455, jul. 1997.

TIDD, J.; BESSANT, J.; PAVITT, K. Gestão da inovação. Porto Alegre: Bookman, 2008. Cap. 1, p. 23-83, Cap. 2, p. 86-130. 


\section{APÊNDICES}

\section{Apêndice A - Roteiro de Entrevista}

\section{Parte I - Identificação do entrevistado e de sua trajetória profissional}

1) Nome do entrevistado

2) Cargo

3) Tempo de trabalho no cargo

4) Tempo de trabalho na empresa

5) Trajetória Profissional (formação, experiências, etc.)

\section{Parte II - Caracterização geral da empresa}

1) Nome da empresa

2) Tipo de empresa

a. Natureza jurídica

b. Porte

C. Faturamento

3) Quais são os departamentos e equipes que compõem a empresa? Qual a estrutura hierárquica?

4) Qual a origem da empresa? Ela faz parte de um grupo ou é independente?

\section{Parte III - Caracterização dos principais segmentos de atuação}

1) Quais são os principais serviços ofertados pela empresa?

2) Quais são os principais clientes? Há segmentação dos clientes em relação aos serviços ofertados?

\section{Parte IV - Identificação do processo de inovação}

1) Identificação das inovações: há mudanças significativas nos serviços prestados, na forma de organização, nos mercados/clientes-alvo da empresa ou nas tecnologias utilizadas nos últimos anos?

2) Descrição dos processos de inovação (para cada inovação, definir):

a. Procura: Onde se originou o projeto de inovação (própria empresa, concorrente ou cliente)? Como surgem as ideias de inovação (em momentos formais ou informais)? 
b. Seleção: Quem é o responsável por aprovar determinado projeto de inovação? Quais os critérios para seleção?

\section{c. Implementação:}

i. Aquisição de Conhecimentos: quais conhecimentos ou habilidades contribuíram para o desenvolvimento da inovação? Estes conhecimentos e habilidades já existiam na empresa? As competências do cliente foram fundamentais na inovação?

ii. Execução:

1. Quem são os atores engajados na inovação (internos e externos)?

2. A cooperação contribuiu para as inovações? Há relato de problemas na cooperação?

3. Barreiras à inovação: quais as dificuldades no desenvolvimento da inovação?

iii. Lançamento: Como foi o gerenciamento do processo inicial de adoção da inovação no mercado/na empresa? Como é a atuação do marketing nesta etapa?

iv. Sustentabilidade: Há quanto tempo esta inovação foi implementada? Houve momentos de melhorias/adaptações na inovação desde então? Quais os impactos da inovação na empresa e fora dela?

v. Aprendizagem (verificar repetição no padrão de erros): Há momentos posteriores de reflexão sobre os erros ocorridos durante o processo de inovação? Como é feito o aproveitamento destas lições aprendidas em inovações futuras? 


\section{Apêndice B - Organograma do Caso A}

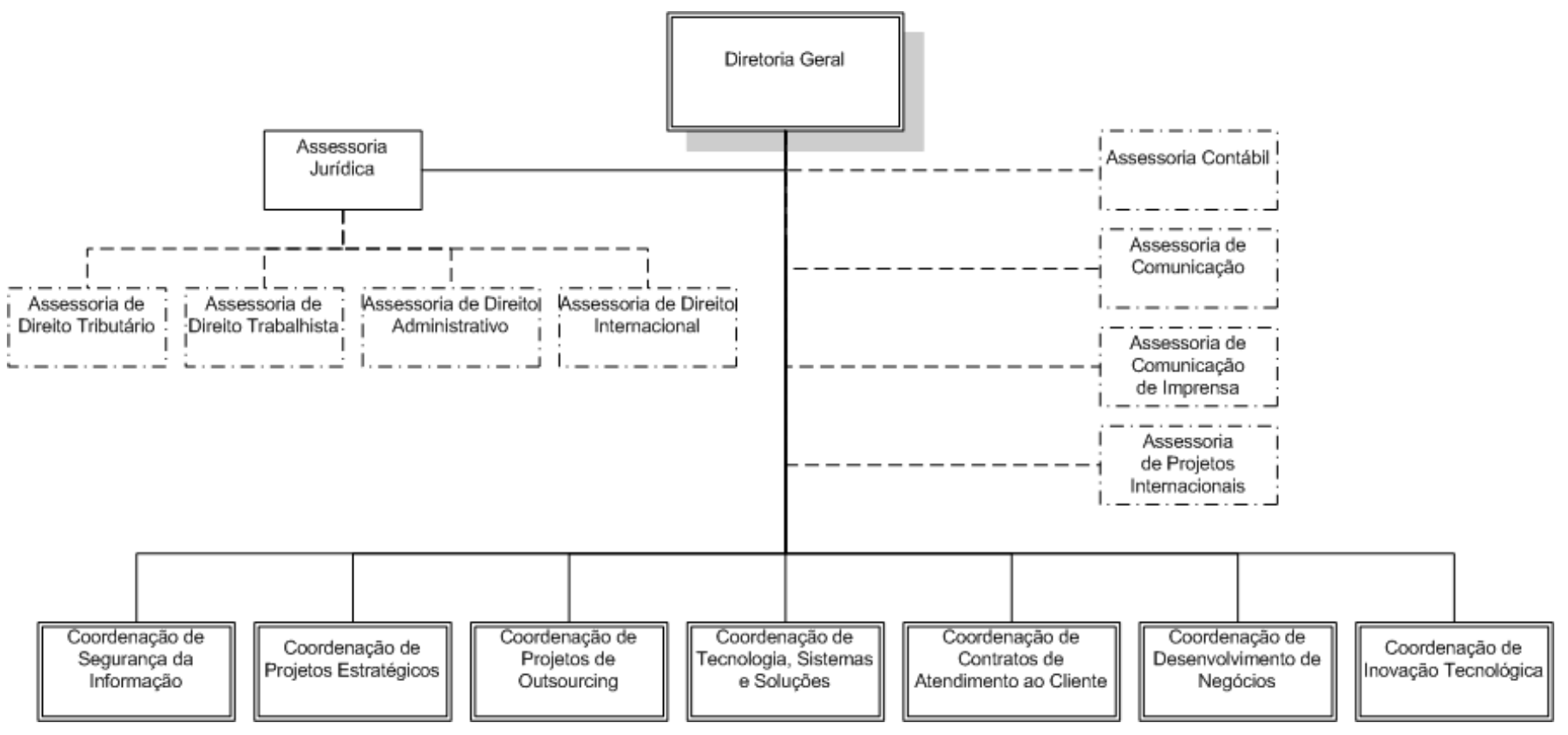

\section{Apêndice C - Organograma do Caso C}

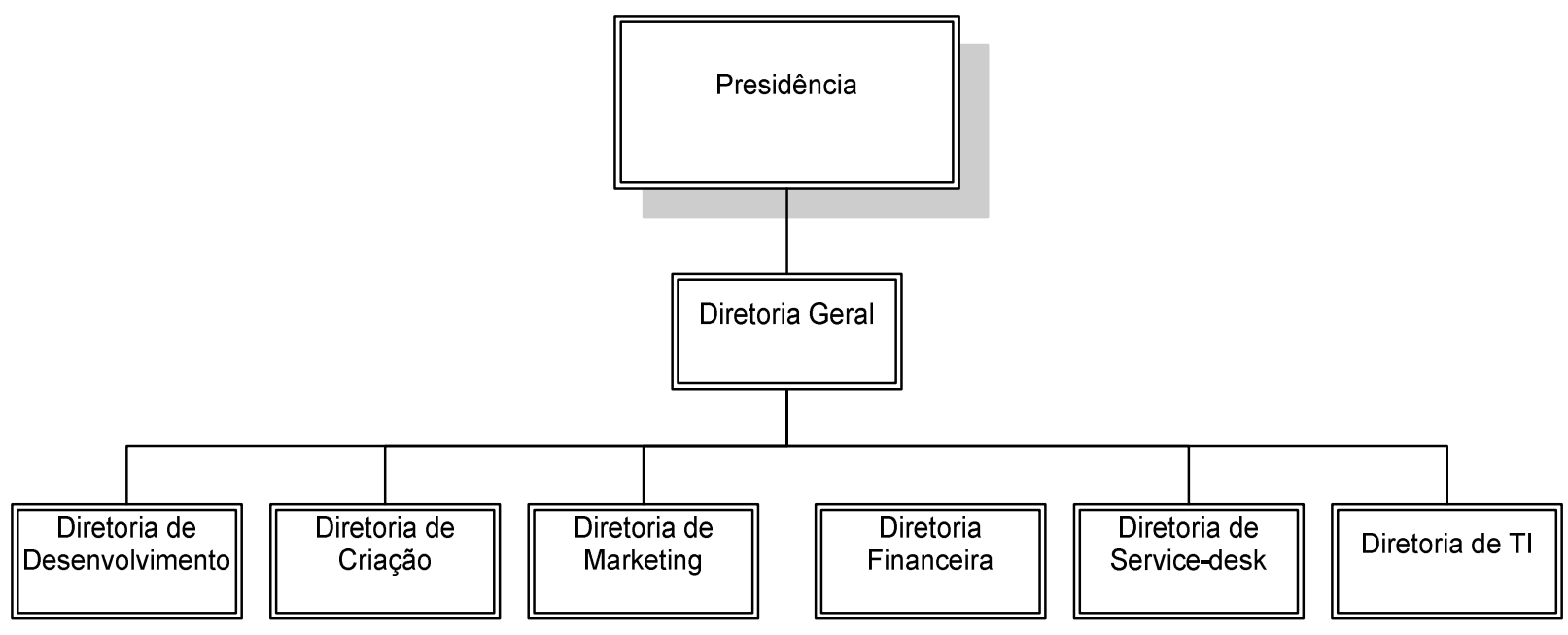




\section{Apêndice D - Organograma do Caso D}

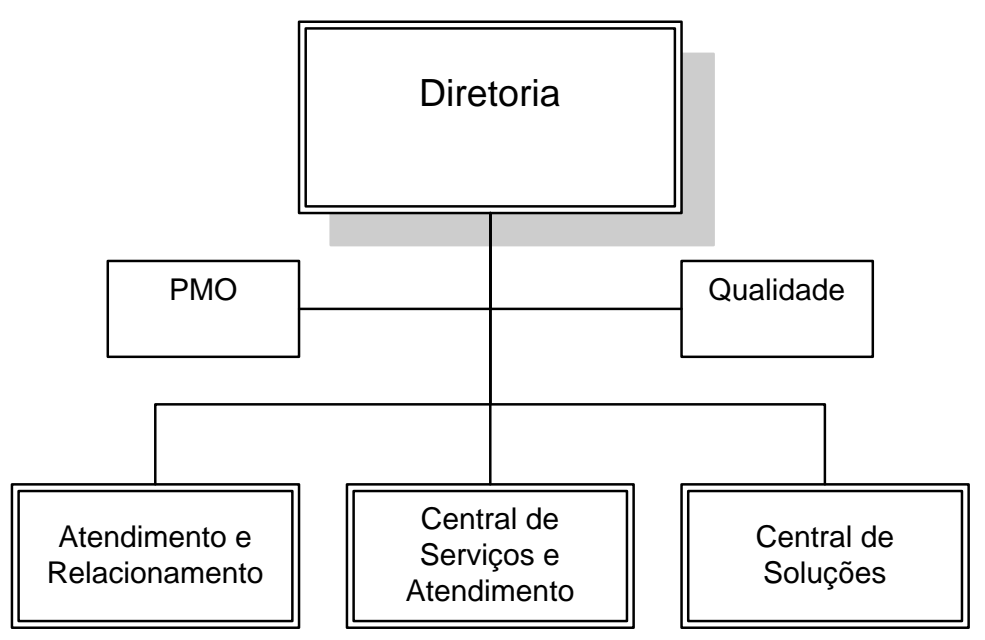

